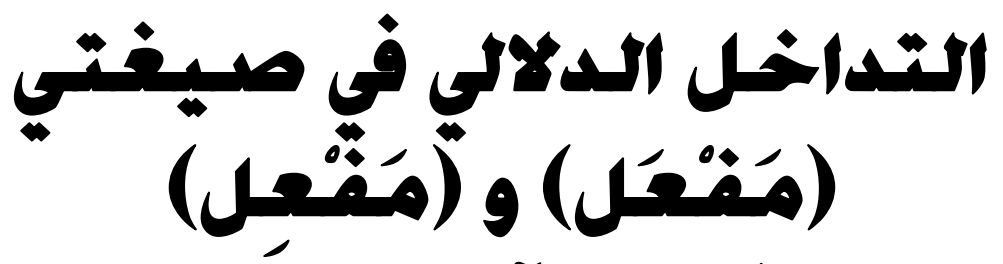

$$
\begin{aligned}
& \text { في القرآن الكريم (مفئ) }
\end{aligned}
$$

$$
\text { إعداد الباحث }
$$

محمد بن مرعي بن محمد الحازمي 
-

$-19 V \varepsilon-$ 


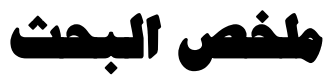

عنوان البحث : ( مَفْعل و مَفْعِل في القرَّن آلكريم ) .

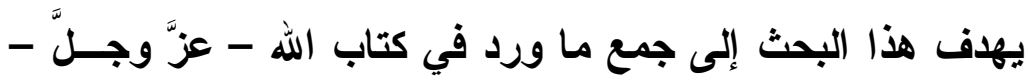

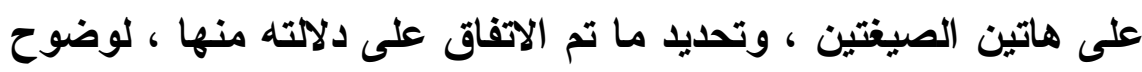

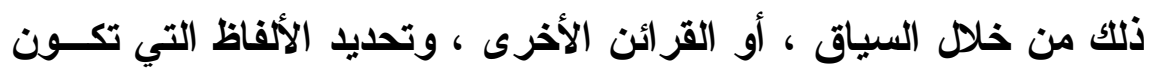

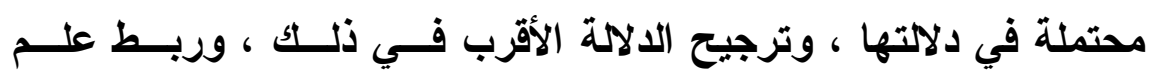

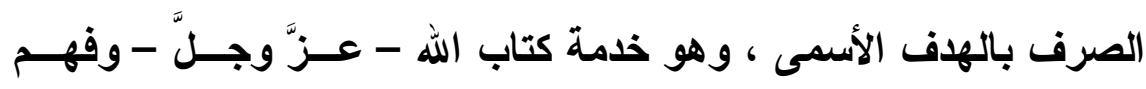

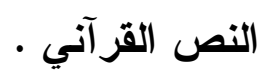

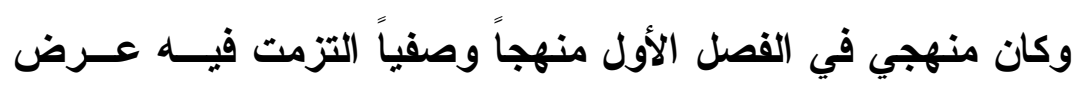

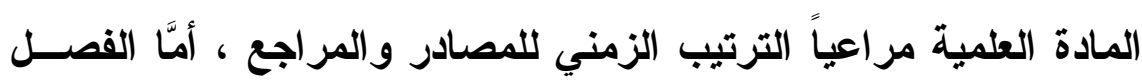

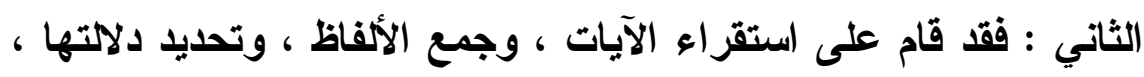

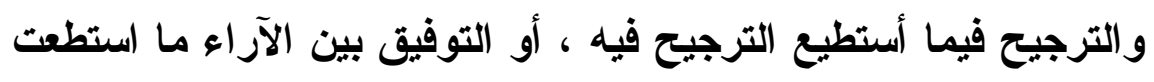
إلى ذلك سبيلاً .

وقد اقتضت طبيعة البحث أنْ يأتي في فصلين ، مسبوقين بمقامسـة

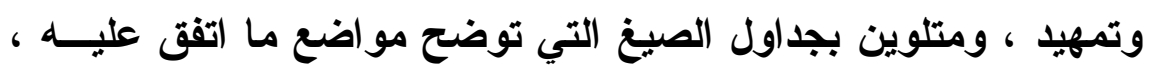

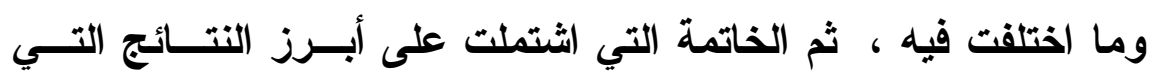
توصلت إليها من خلا البحث ، ثم ذيلت ذلك بالفهارس الفنية التي تذلت التل

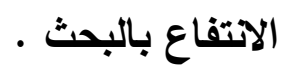

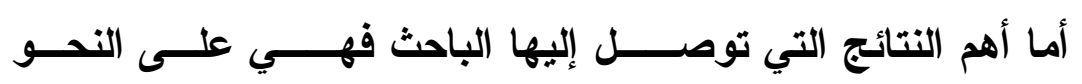
الآتي : 
ا-ـ العلاقة الوثيقة بين النحو والصرف ، ويظهر ذلك في توجيه النحــو

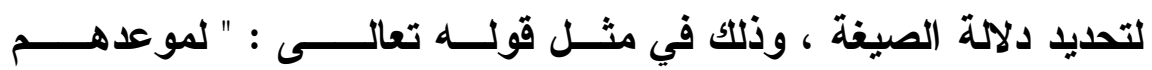

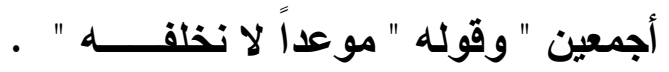

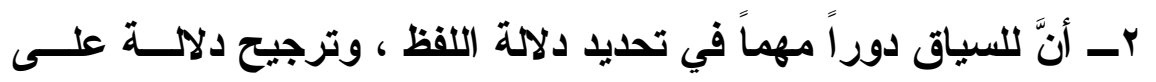
الأخرى r- قـ تترجح دلالة لفظ من الألفاظ بالنظر إلى سبب النزول ، أو قراءة من القراعات ، مثل لفظة ( مَعَاد ) في قوله تعالى : " لر ادلك إلى معاد " .

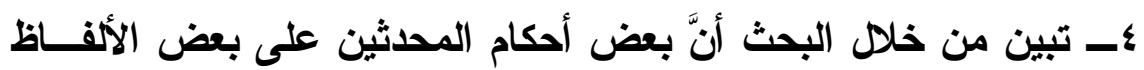

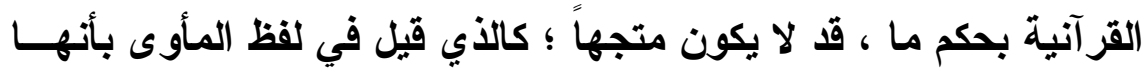
ليست مصدراً ميمياً في القرآن الكريم ، في حين أنَّ الباحث وجد ما يفيد دلالتها على المصدر الميمي ، في قوله تعالى : " عندها جنة المأوى " .

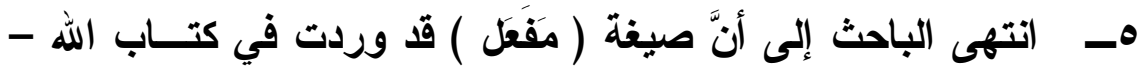

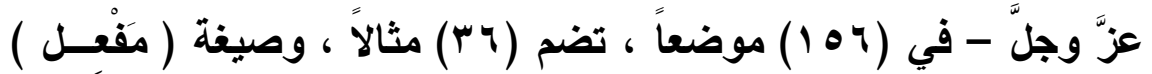

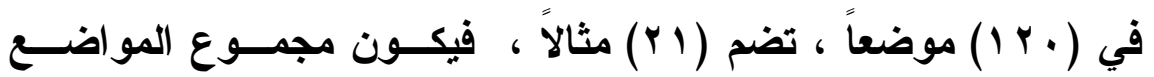
( ) موضع ( T P )

\section{اسم الباحث}

محمد بن مرعي بن محمد الحازمي 


\section{المقدمة :}

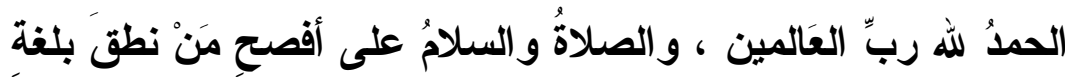

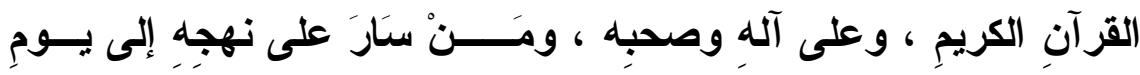
الاين .

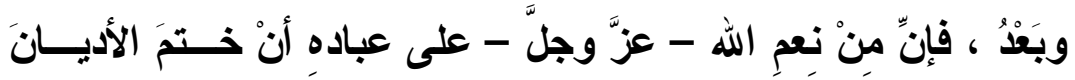

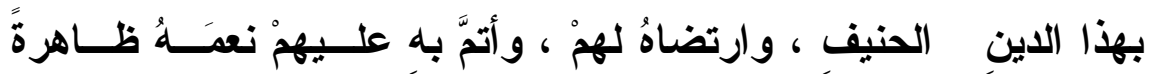

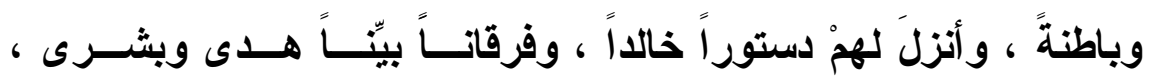

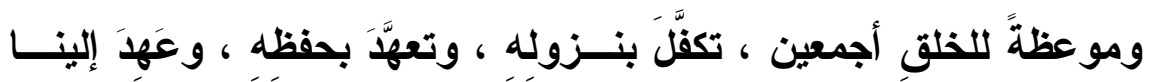

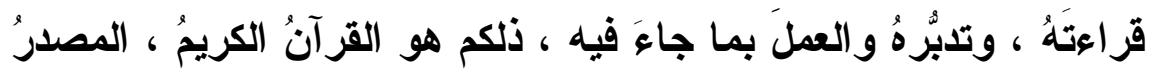

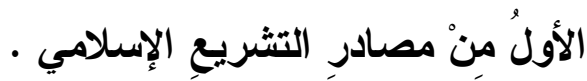

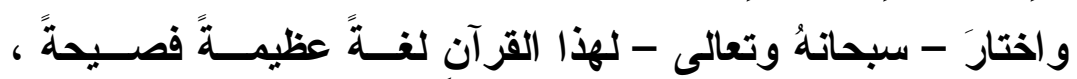

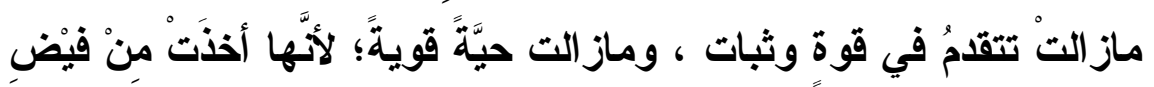

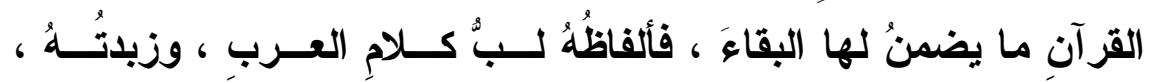

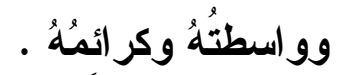

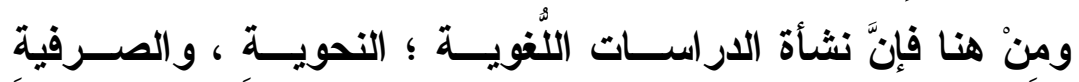

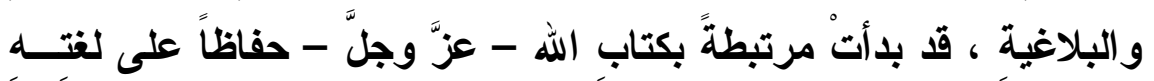

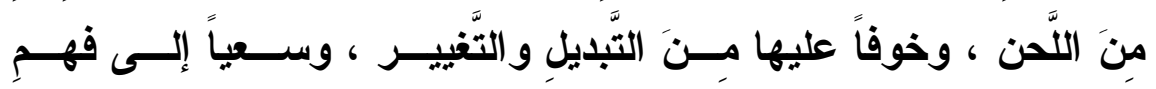

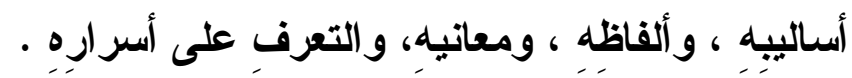

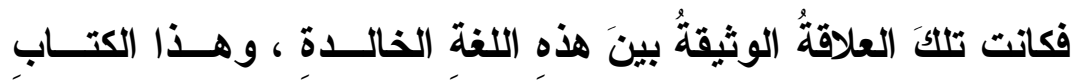

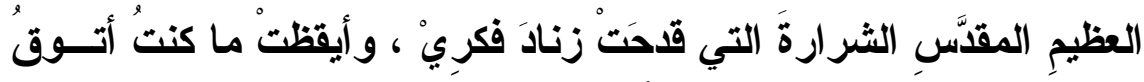

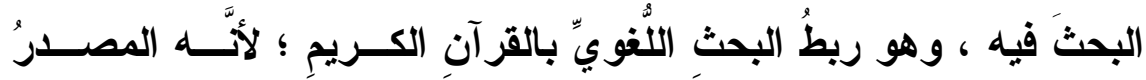

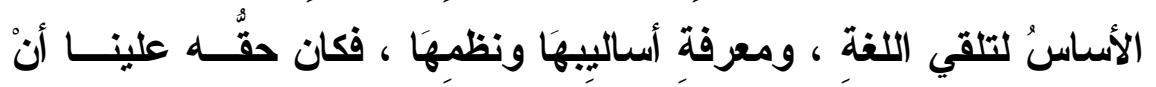




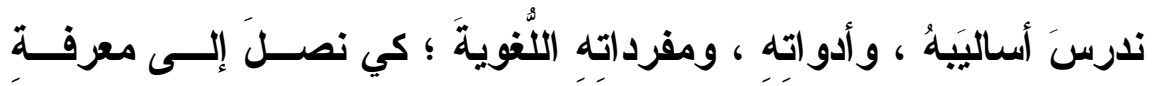

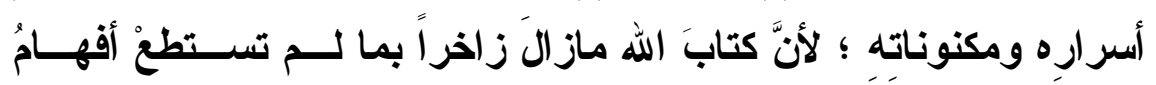

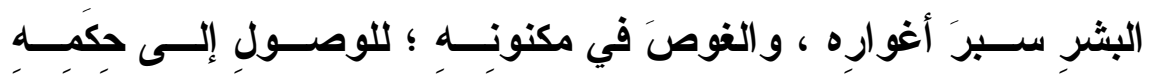

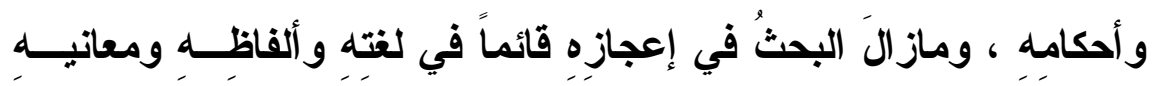

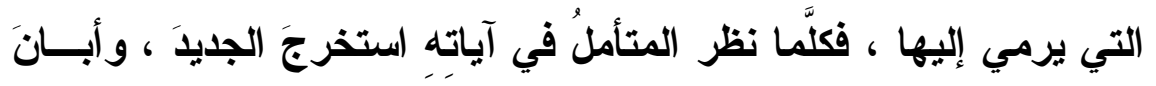
منها المفيَ .

وقد اخترت هذا العنوان ليكون موضوعًا لبحثي ؛ لأنَّ الناظر في هاتين

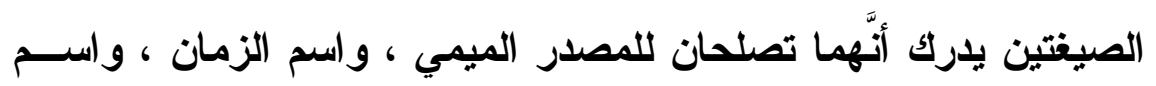

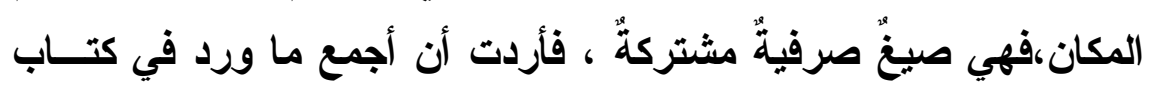

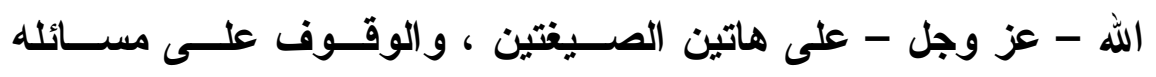

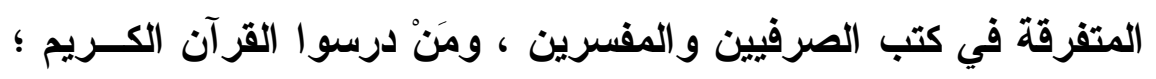

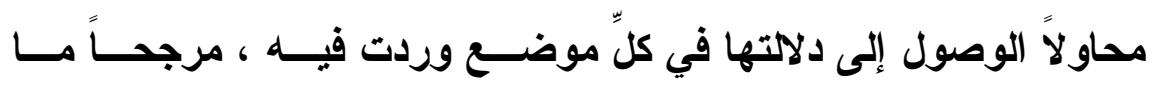

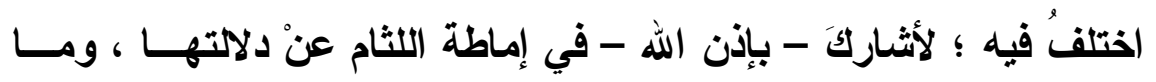
ترمي إليه . وثمة أسبابٌ دفعتني لاختيارِ هذا الموضوع لبحثي ، وهي :

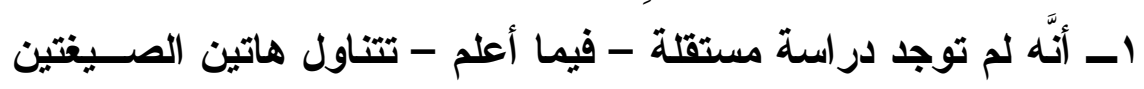

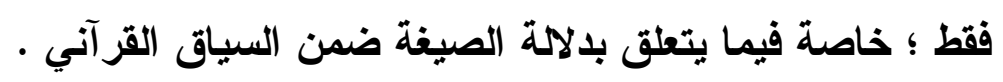

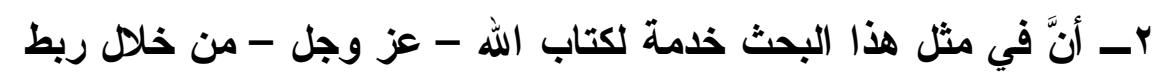

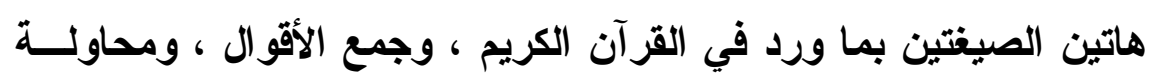

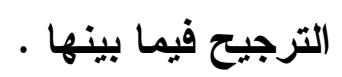

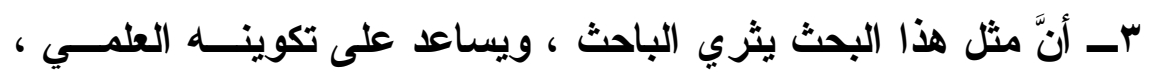

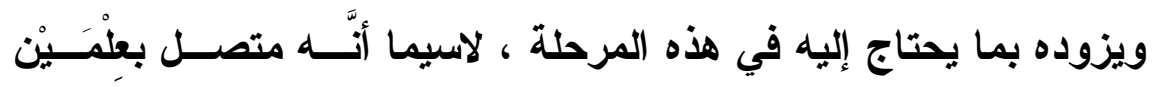

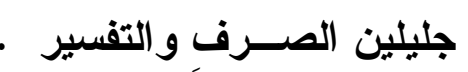


عـــ أنَّ هذا البحث محاولة لفهم البنية الصــرفية ، وخــدمتها للمعنـى التفسيري وقد جاء البحث في فصلين ، مسبوقين بمقامــة وتمهيـــ ، ومتلـــوين بخاتمة .

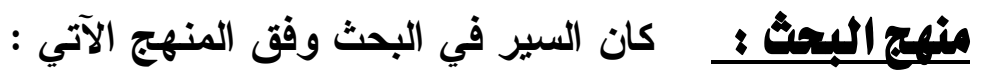
أ - التزمت بهاتين الصيغتين المشتقتين فقط .

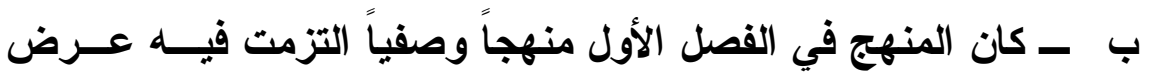
المادة العلمية مراعياً الترتيب الزمني للمصادر والمراجع ، دون تكــرار في ذلك إلا إذا دعت الحاجة فيه إلى توضيح غامض ، أو إضافة شــاهد مدعماً كل ذلك بما ورد من شواهد قر آنية وشعرية . ج - أمَّا الفصل الثاني فقد كان سيري فيه على النحو الآتي : ا-ـ استقراء الآيات القر آنية ، وجمع الألفاظ ، وتحديد دلالتها . r- دراسة تلك الألفاظ من خلا كتب الصرف ، وكتب التفسير ، وكتـب التب القراعات إن كان في اللفظة قراعات . rـ تقديم كل لفظة بالمعنى اللغوي العام ، وما ترد فيه من اســتعمالات مختلفة ، مع بيان ما حدث في اللفظ من إعلال إن وجد . عــ توضيح ما ورد من قراعات في اللفظة ، والتعويـلـل علــى قــراعة

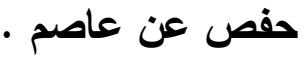
๑ـ إبراز آراء المفسرين المختلفة ، والترجيح فيما أسـتطيع التــرجيح فيه ، أو التوفيق بين الآراء ما استطعت إلى ذلك سبيلاً . \- سوف أراعي الترتيب الزمني للمصادر والمر اجع ،وسأكتفي بأمئلـــة لبعض الصيغ في كل مبحث . 


\section{اللدراسات السابقة:}

يسنَّ الله - عز وجل - لي أنْ أطَّع على مجموعة من الدراســات

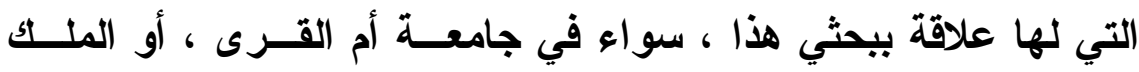

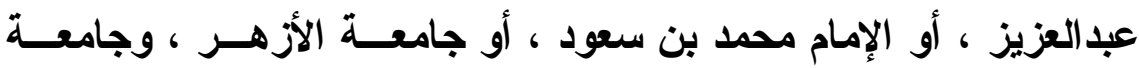

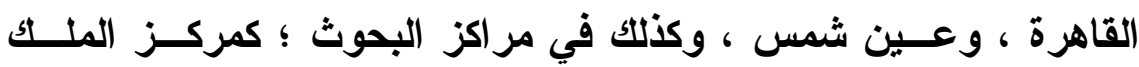

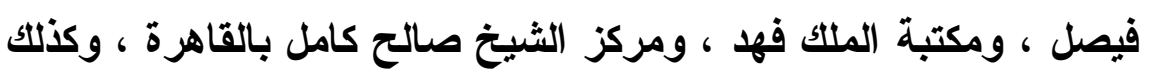

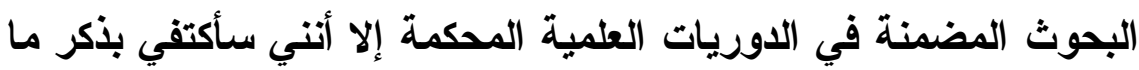

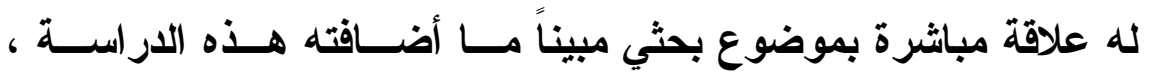

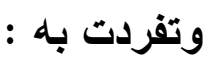

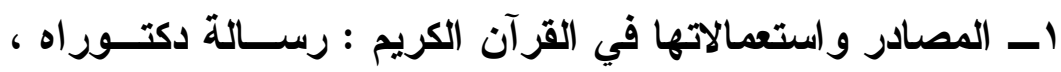
للباحث : محمد المختار محمد المهذي ، جامعة الأزهر .

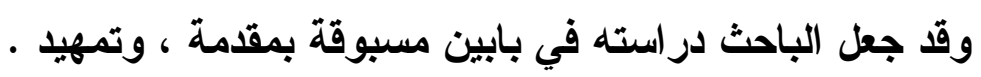

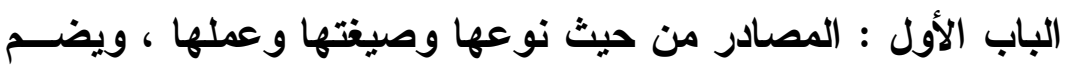

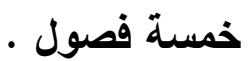
الباب الثاني : استعمال القرآن الكريم للمصـــادر ، وفيـهـ ثلاثـــــة

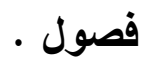
وقد التقى بحثي معه في الفصل الثاني من الباب الأول عند حديثـهـ

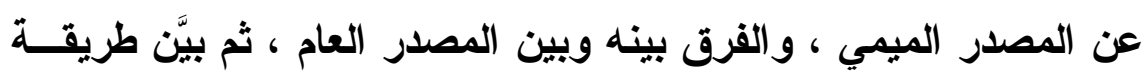

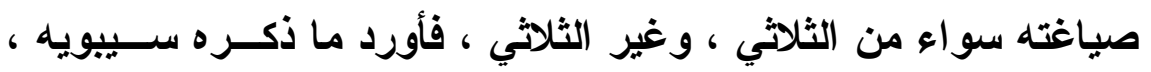

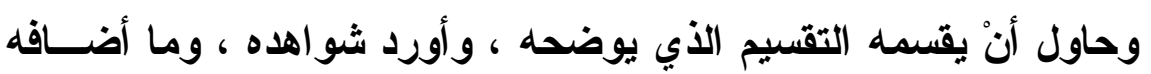

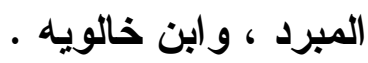

وقد تحدث الباحث في الفصل الثاني من الباب الثاني عن المصــادر

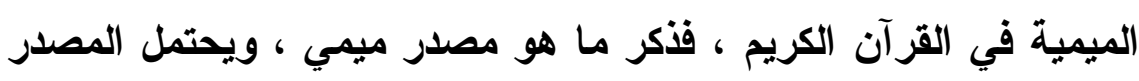


الميمي واسم المكان واسم الزمان ، و اكتفى فــي ذلـــك بالإثـــارة فــي

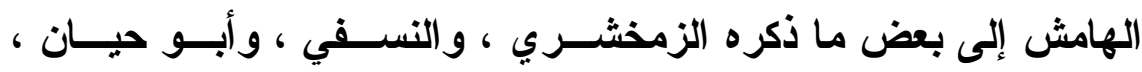
و السيوطي ، ومعجم ألفاظ القرآن ، و الجمل على الجلالين .

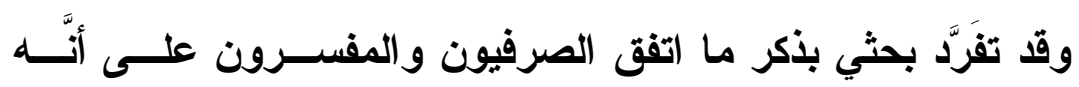

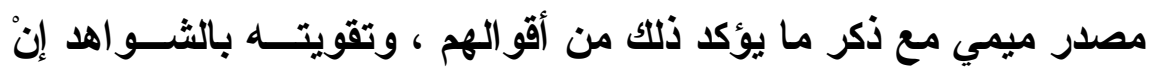

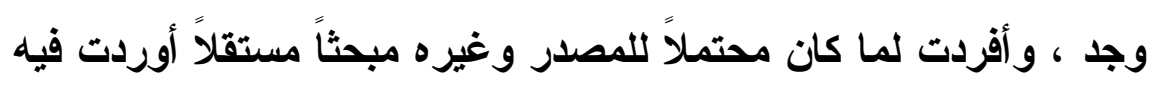

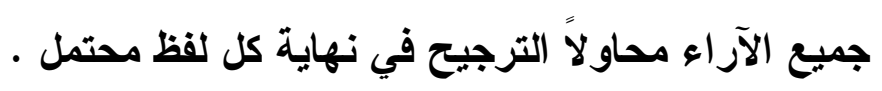

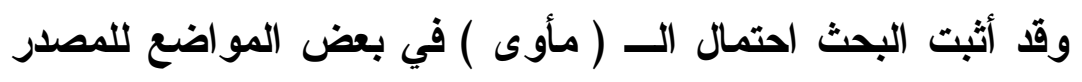

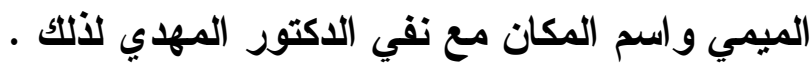

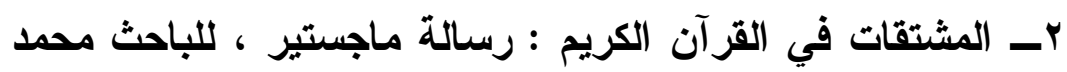
خليل نصر الله فرَّاج ، جامعة القاهرة ، كلية الآداب .

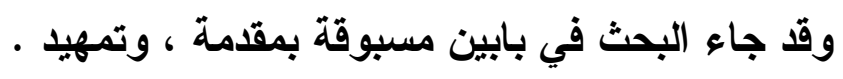

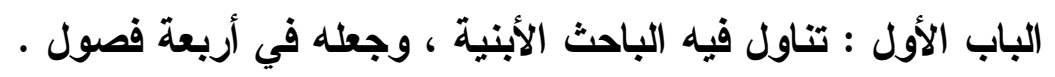

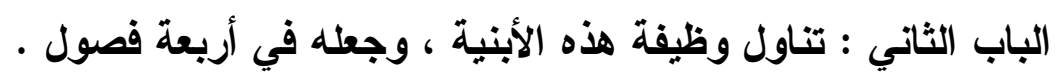

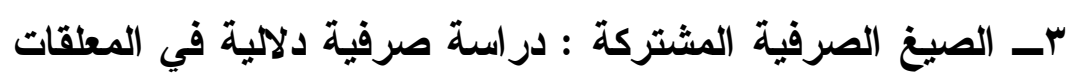

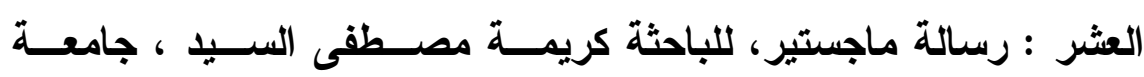

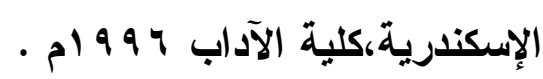

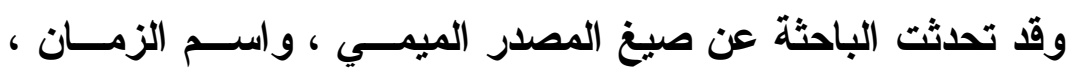

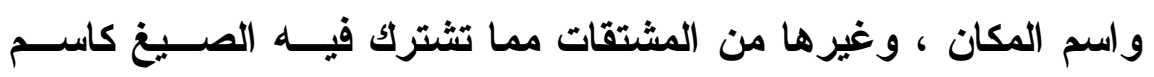

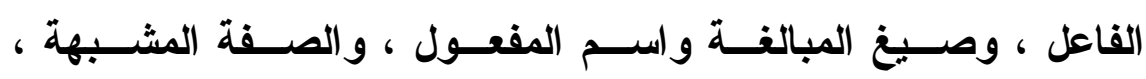

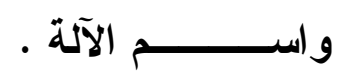

أمَّا بحثَي فقد درس صيفتين صرفيتِين هما : مَفْعل و مَفْعِل ، وكسـان مجال التطبيق في القرآن الكريم ، وقد وققت عند كلّ لفظة منها . 
ولم يكن همي الإحصاء ، بل الوقوف على تلك الدلالة ، والتــرجيح ما أمكنني ذلك . ومن هيم

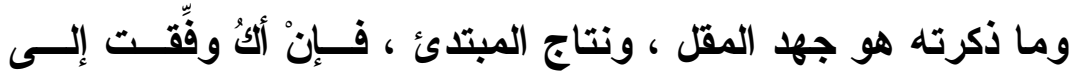

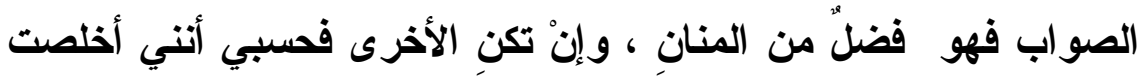

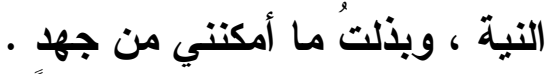

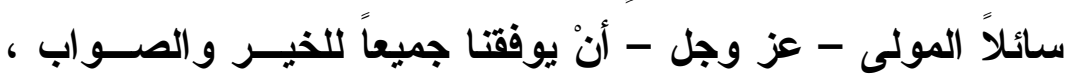
وخدمة لغة الكتاب . 


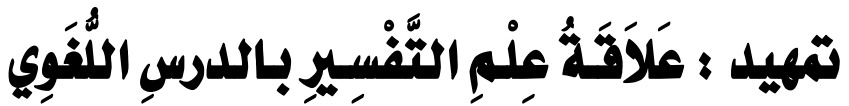

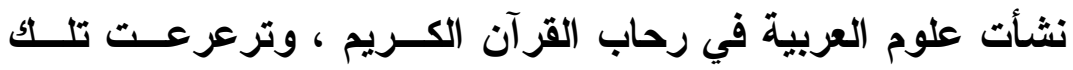

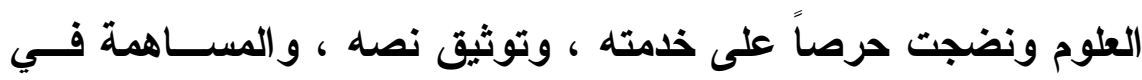

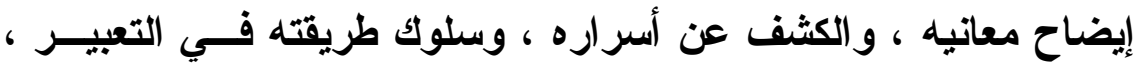
ويناء قو اعد العربية على الفصيح . فلا شكك أنَّ القرآن الكريم هو الأصــل الأول مــن أصــول النحــو

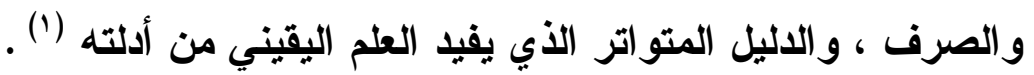

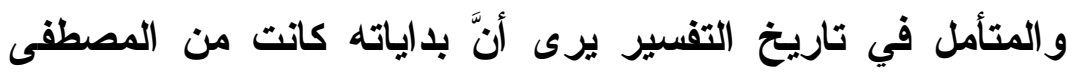

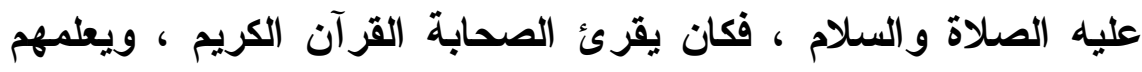

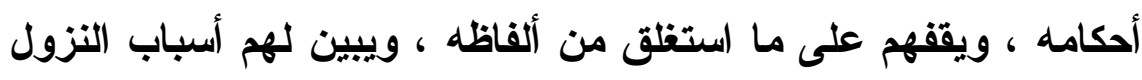

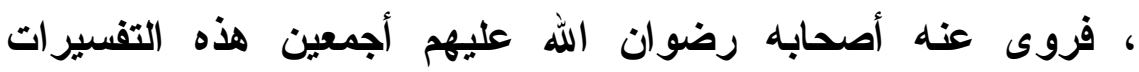

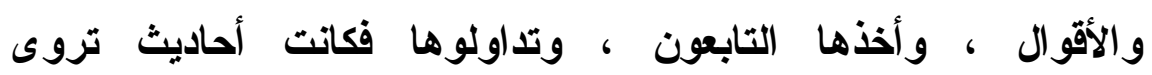
وتنقل ، وكان ما يغلب على ذلك التفسير ، الطابع اللغوي ، فقد روي أنَّ التهائ

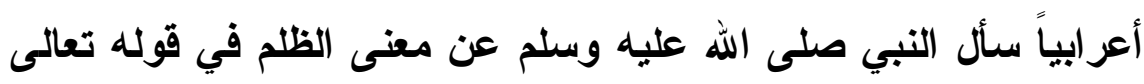

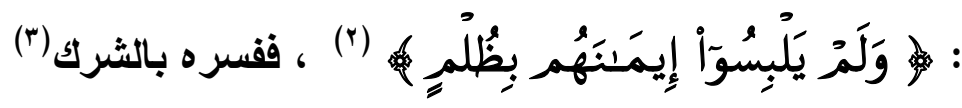

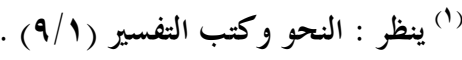

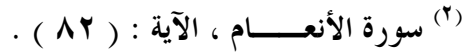

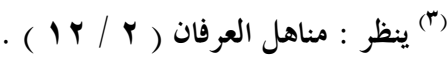


وتورع كبار الصحابة من القول في التفسير ، فهذا أبو بكر -

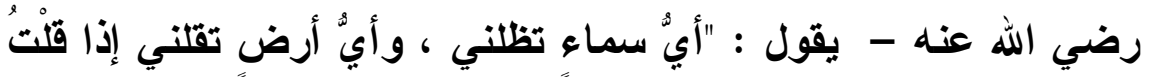

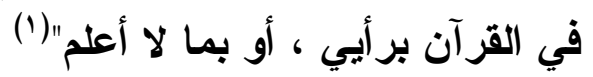
وعلى النقيض من ذلتك نجد ابن عباس - رضي الله عنه - جريئـاً

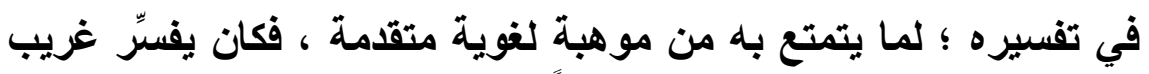
القرآن ، ويشرح معانيه ، ويقرنه بأثعار الجاهلين ، وقد قال في ذلتك :

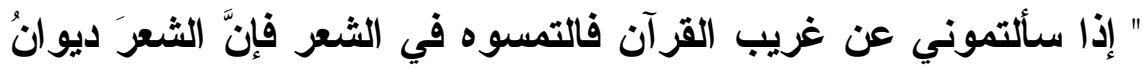

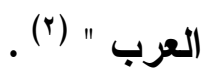
وتجدر الإثشارة إلى أنَّ تفسير الصحابة للقرآن الكـريم ، وكـــلك

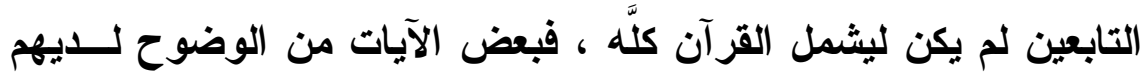

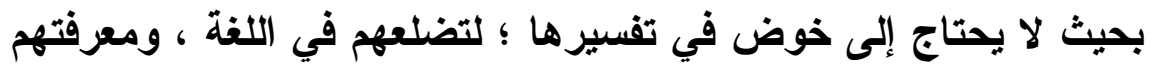

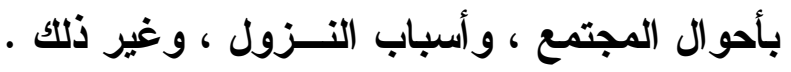

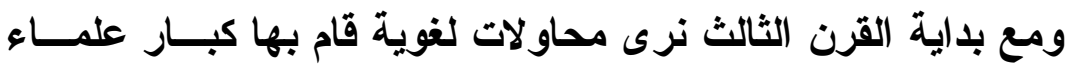

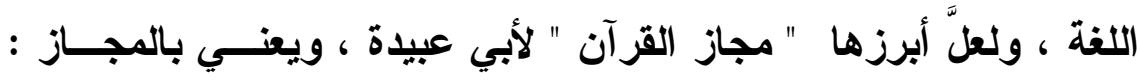

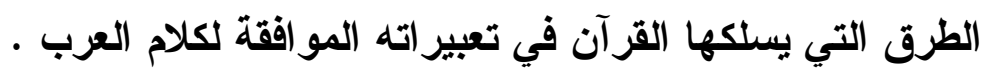
وجاء بعده الأخفش و الفراء ، و أطلقوا على كتبهم ( معاني القرآن )

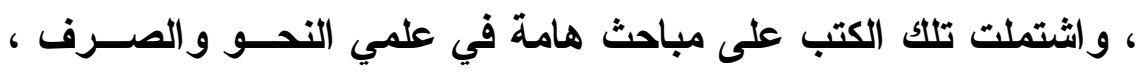
فهي مصدر هام لدارس اللغة . فغدت علوم العربية ركناً من أركان التفسير ، وأداة من أدواته .

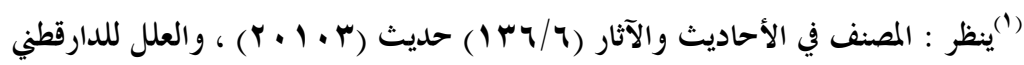

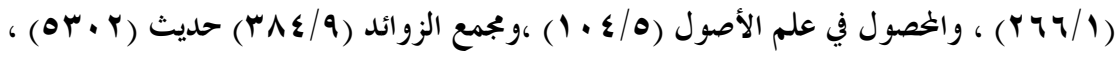

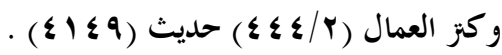

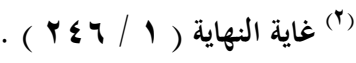


ولمَّا كان موضوع بحثي متعلقاً بكتاب الله - عز وجل - جعلت كتب

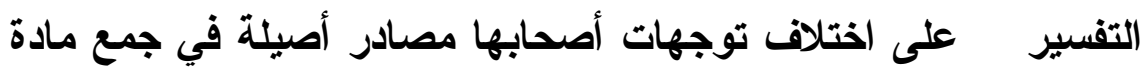

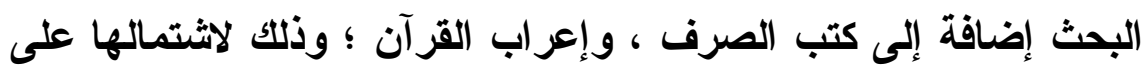

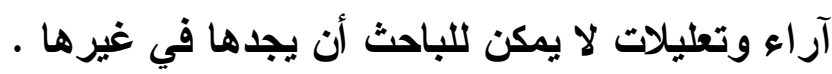




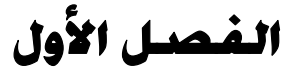

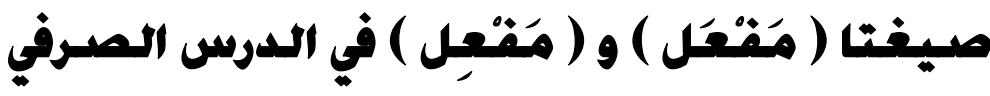 \\ المبحث الأول : المصدر الميهي}

لم يكن مصطلح المصدر الميمي معروفاً عند المتقدمين بهذه الماهي

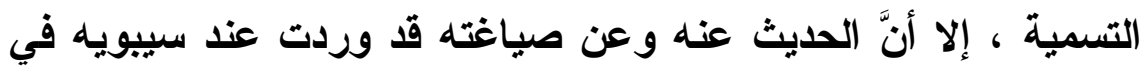

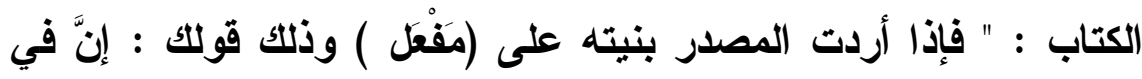

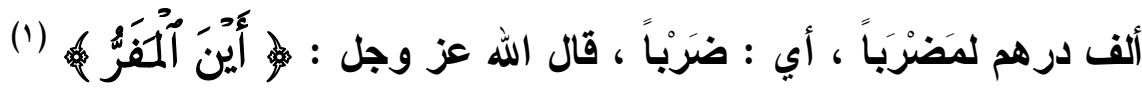
يريد : أين الفرار" (†)، وقد تتبعت هذا المصطلح منذ سييويه (") ، فلم

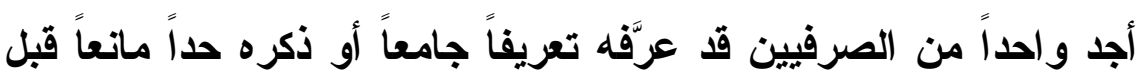

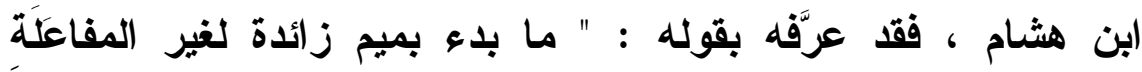

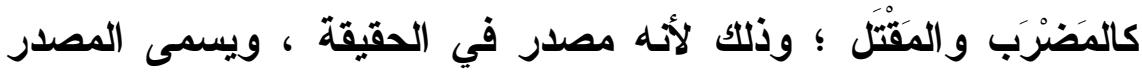

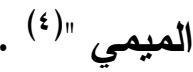
وقد جاء بعده القوشجي فعرَّفه بقوله : " وهو مشترك بين الثلاثي

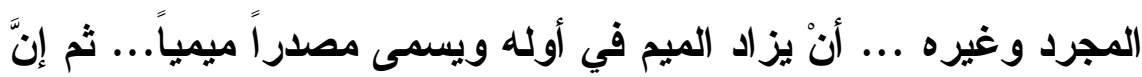

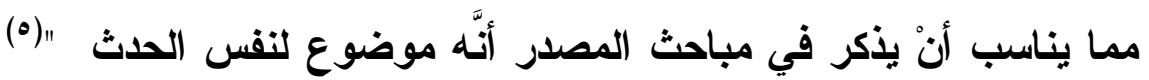

$$
\begin{aligned}
& \text { (1) سورة القيامة ، الآية : ( (1) ). }
\end{aligned}
$$

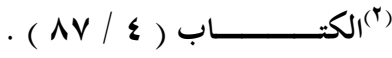

(")

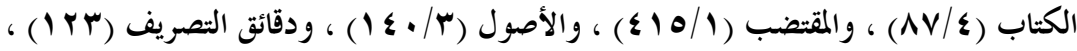

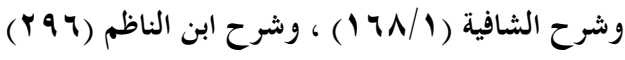

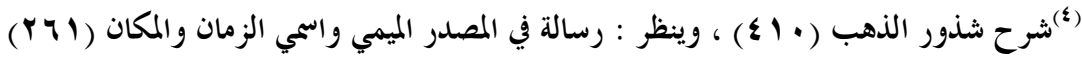

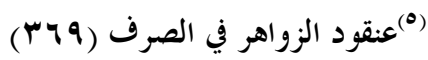


ويدل المصدر الميمي على الحدث المجرد ، ويفيد زيادة على دلالته

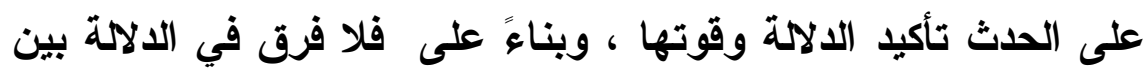

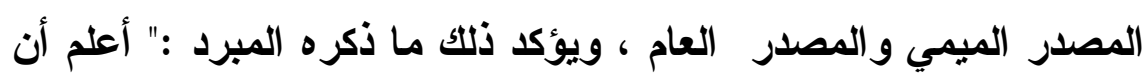

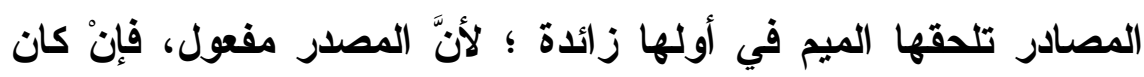

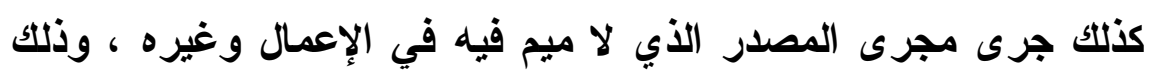

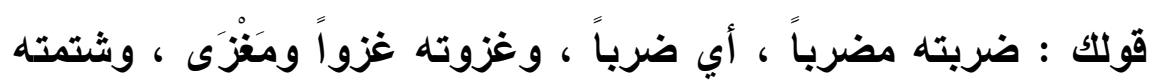

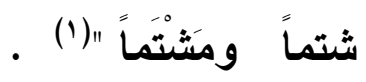
ـ صياغة المصدر الميمي : يصاغ المصدر الميمي من الفعل الثلاثي

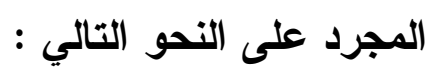
ا-ـ صوغه من الفعل الصحيح : يكون مكسور العين في المضارع أو مفتوحها أو مضمومها

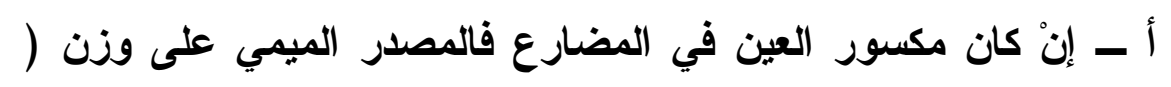

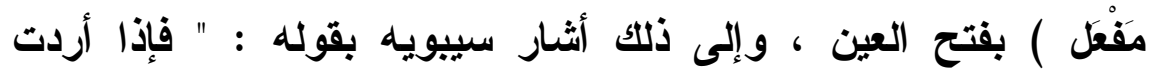

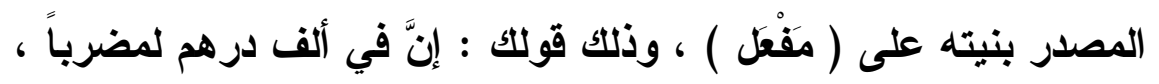

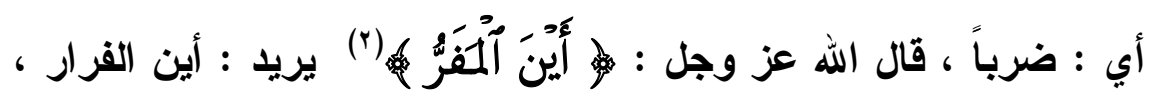

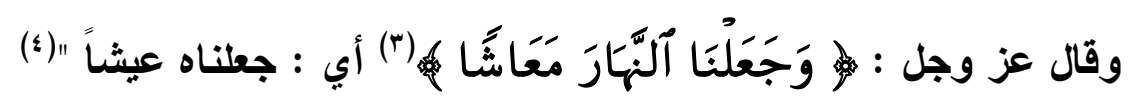

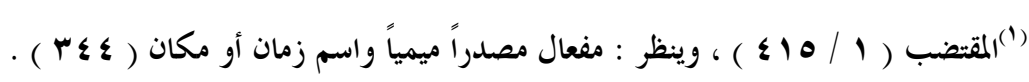
(1)

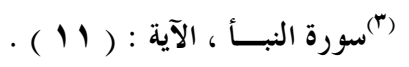
( 
وقال الفراء : " ومن أراد المصدر فتح العين ، مثل : المَضرب

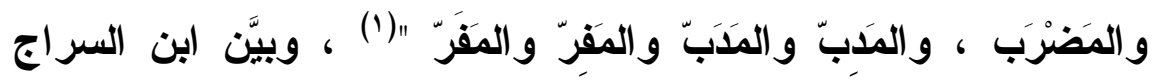

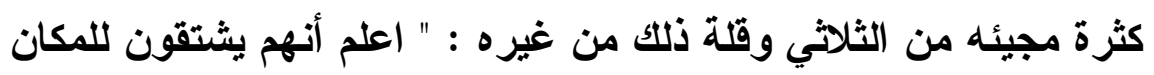
و المصدر والزمان من الثثلاثي ، ولا يكاد يكون رباعي إلا قليلاً أو قياساً ـ الأول:الثلاثي يجيء على مثال الفعل المضارع على ( يَفْعل ) و ( يَفْعَل

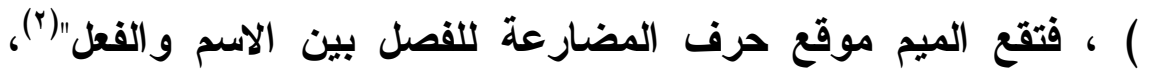

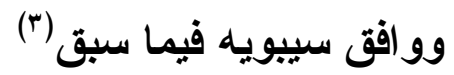

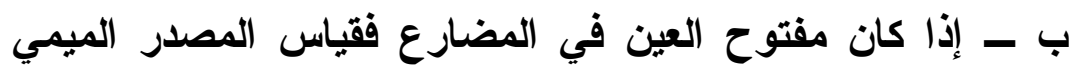

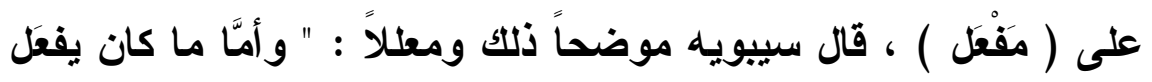

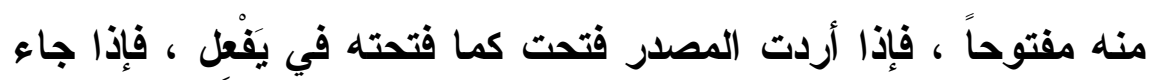

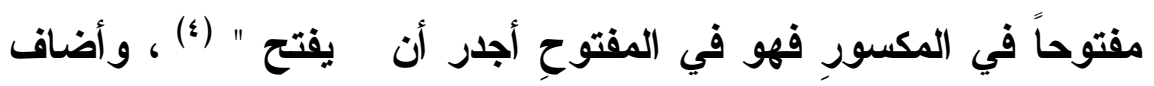

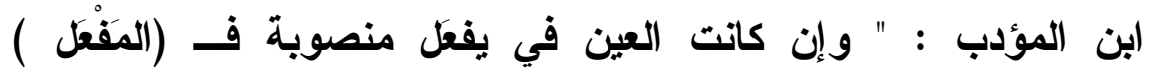

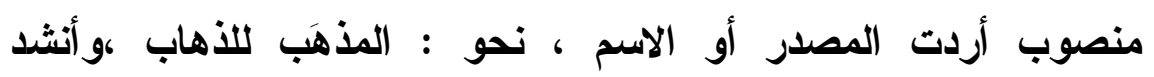

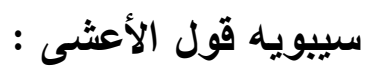

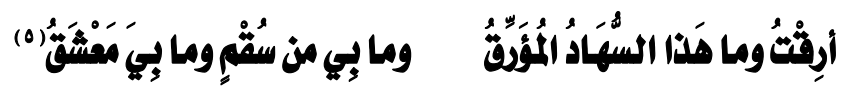

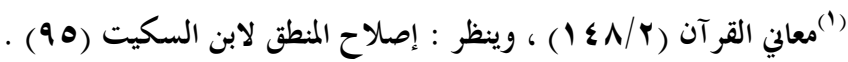

$$
\begin{aligned}
& \text { (T) }
\end{aligned}
$$

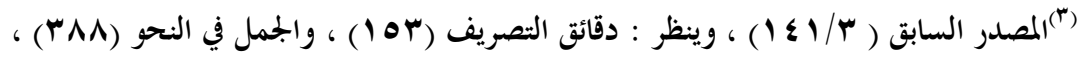

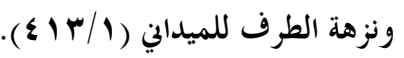

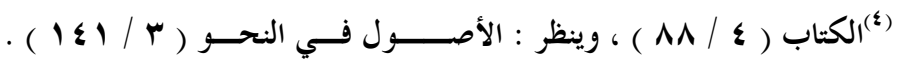

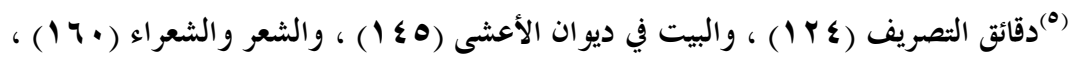

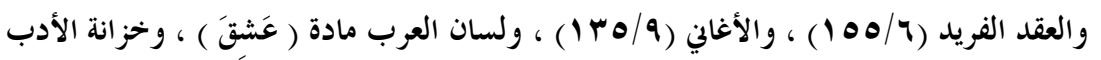

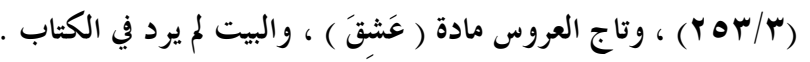


ج - إنْ كان الفعل مضموم العين في المضارع فقياس مصدره

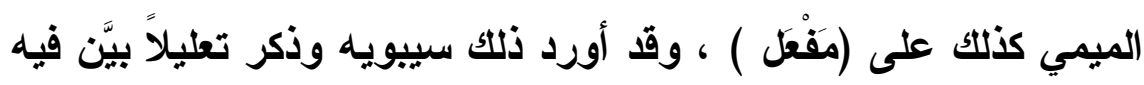

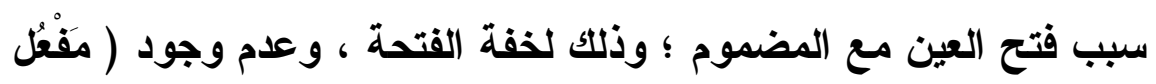

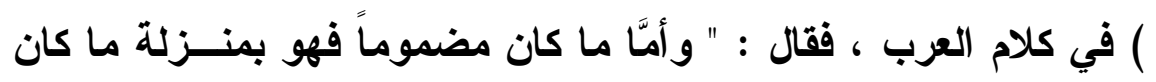

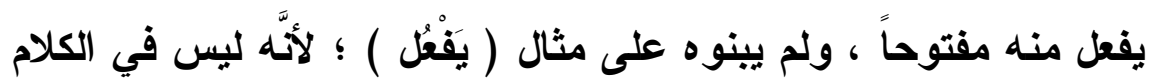

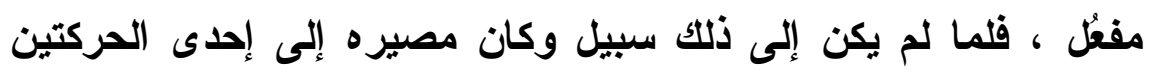

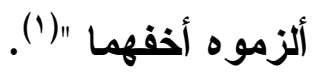

و أكد الفراء فتح العين في المضموم بقوله : " فإن كان ( يفُّل )

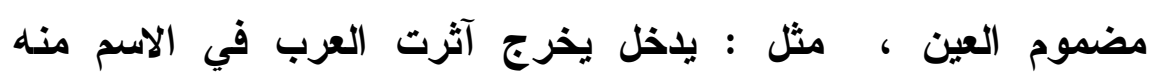

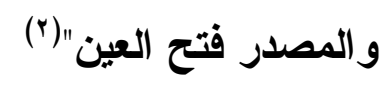

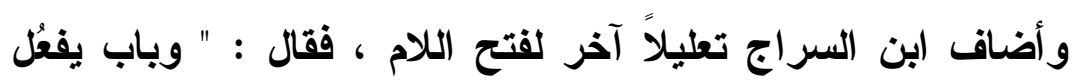

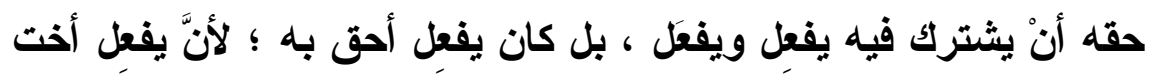

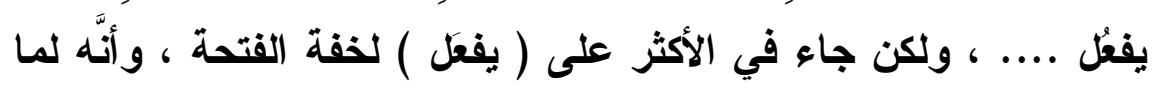

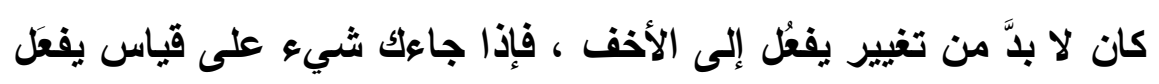

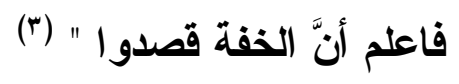
ـ صوغه من الفعل المعتل : قد يكون الفعل المعتل :

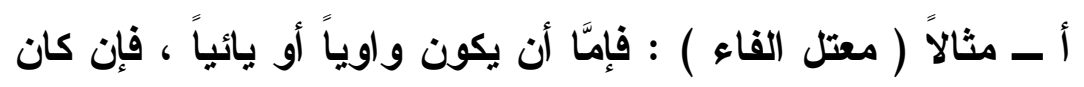
الفعل واوي الفاء و الماضي منه مفتوح العين و المضارع مكسورها (

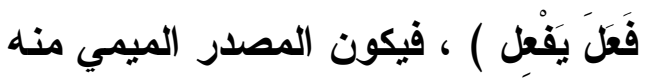

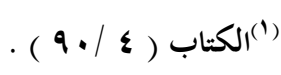

$$
\begin{aligned}
& \text { (") }
\end{aligned}
$$

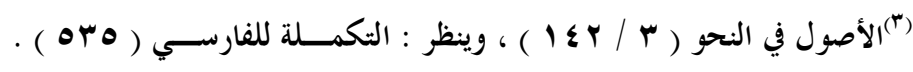

$$
\begin{aligned}
& \text { - - 1919 _ - }
\end{aligned}
$$


على ( مَفْعِل ) بكسر العين ، وإن كان ماضيه مكسور العين ومضارعه

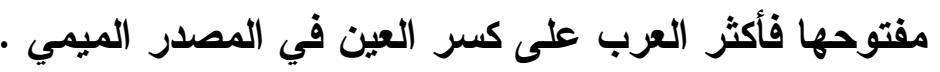

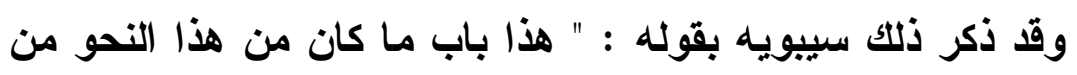

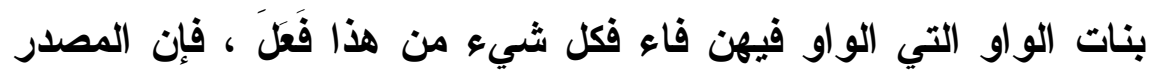

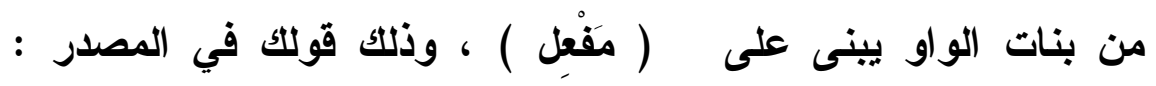

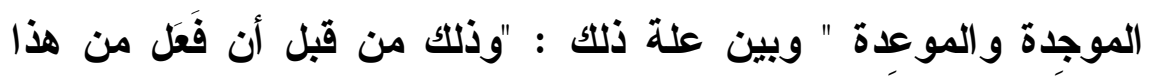

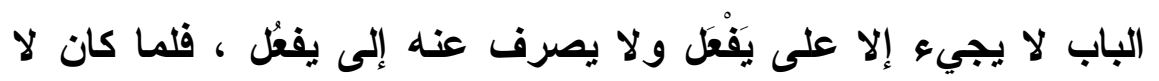

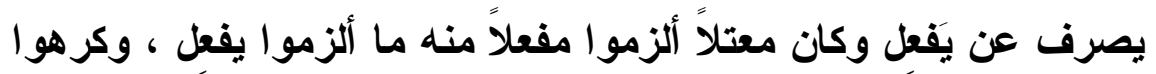

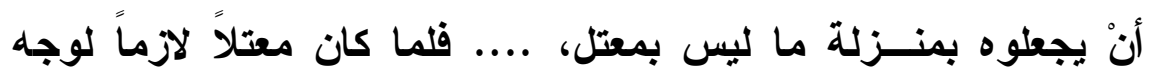

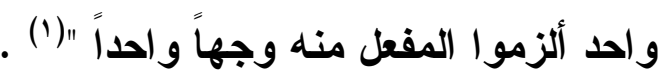

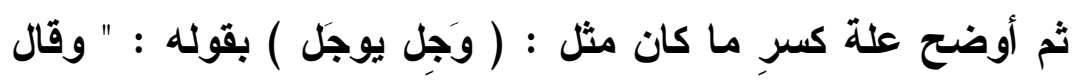

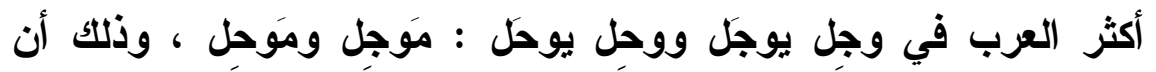

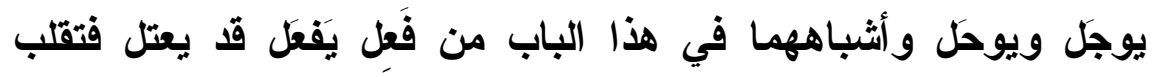

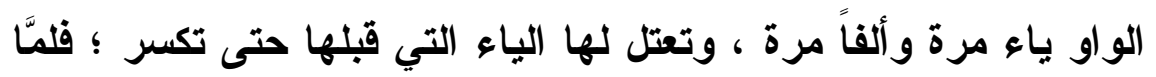

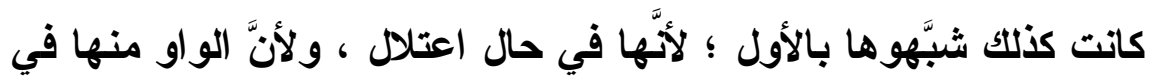

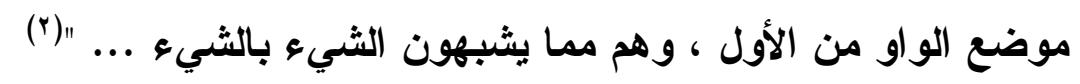

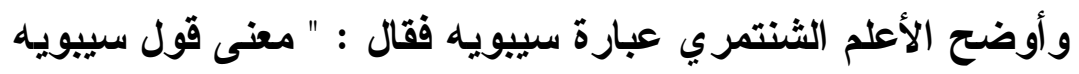

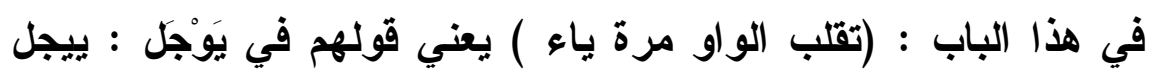

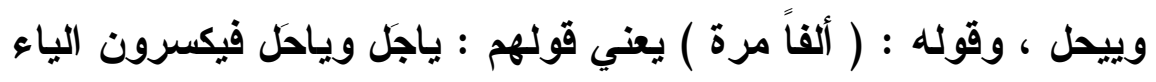

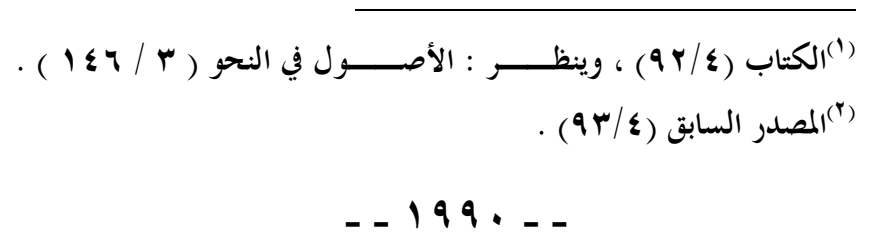


الأولى وحقها الفتح وقََّى سييويه كسرة الموجل والموحلِ ، وإن كان

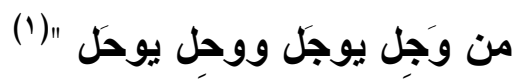

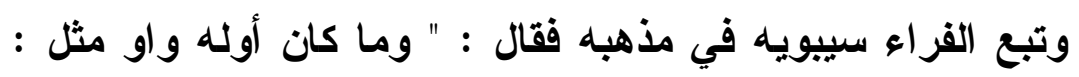

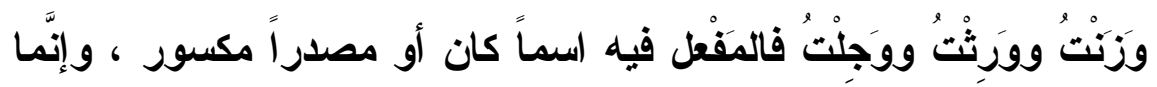

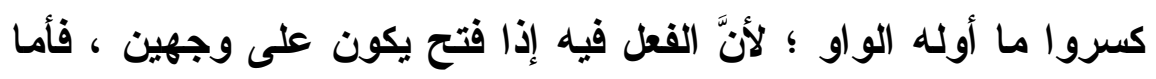

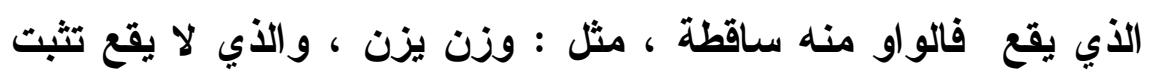

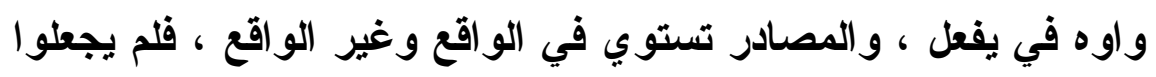

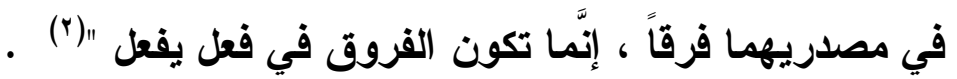

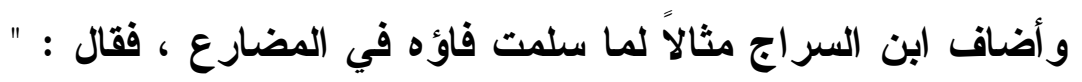

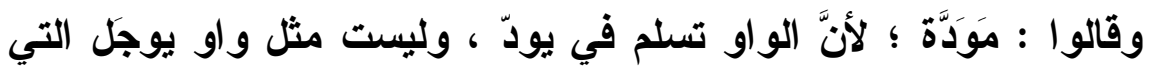

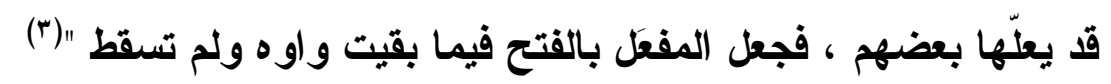

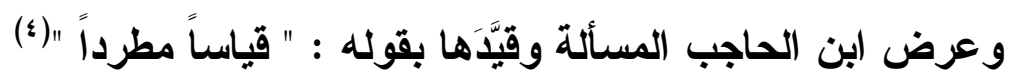

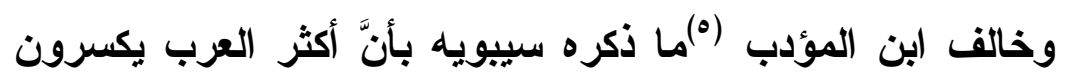
العين مثل : ( موجِل ومَوحِل ) ، فجعل المفْعَل بفتح العين فيما كان مثالاً

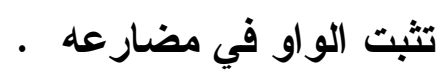

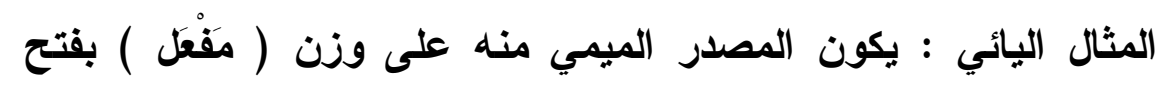

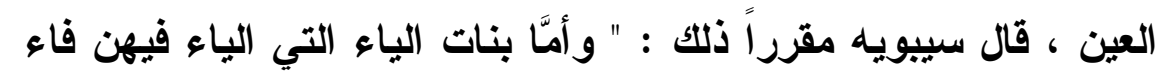

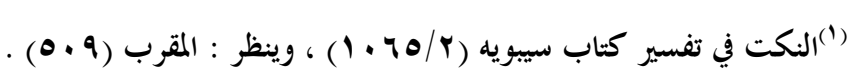

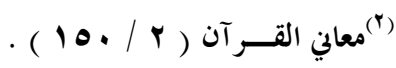

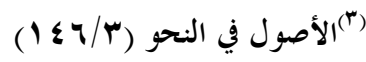

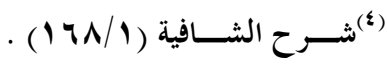

$$
\begin{aligned}
& \text { (o) } \\
& -1991=
\end{aligned}
$$


فإنها بمنـزلة غير المعتل ؛ لأنَّها تتم ولا تعتل ، وذلك أنَّ الياء مع الياء

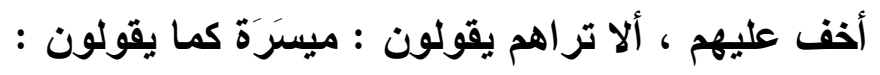

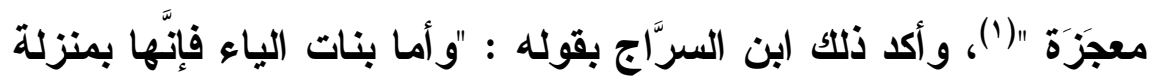

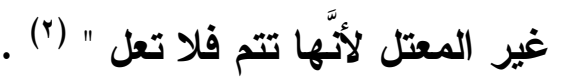

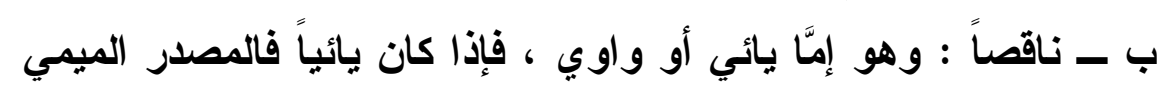

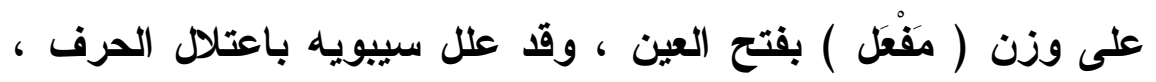

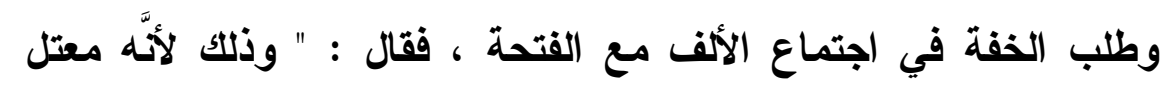

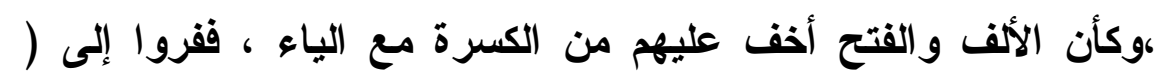

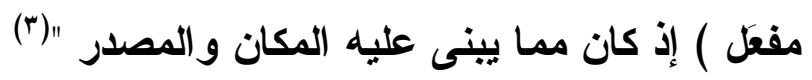

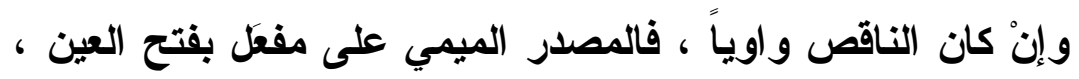

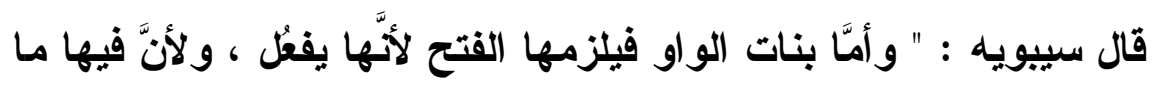

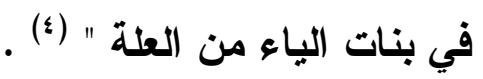

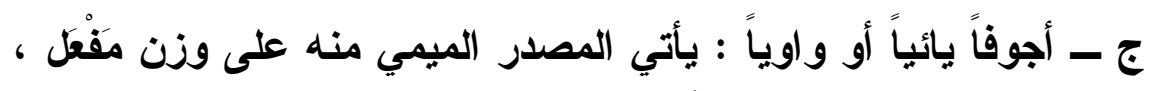
وهو ظاهر كلام سيبويه ؛ لأََّّه جعل المفعِل قليلاً ومسموعاً عندما قال :

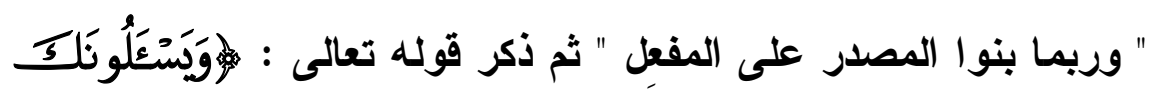

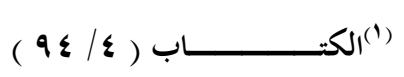

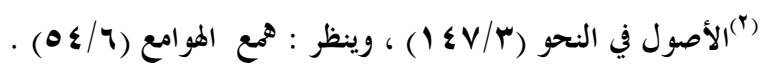

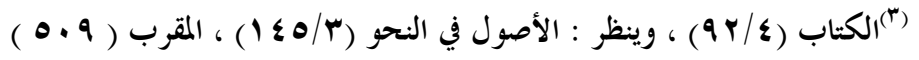

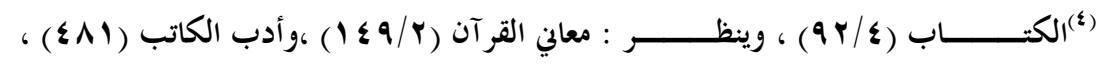

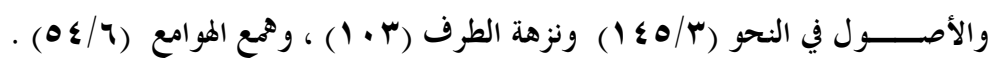

$$
\begin{aligned}
& \text { - - 199r _ - }
\end{aligned}
$$




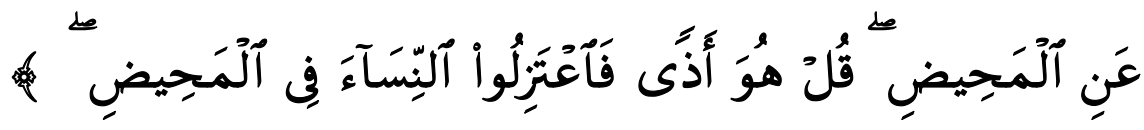

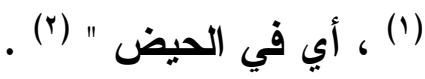
و أكد ذلك الفرَّاء بقوله " و إذا كان المفعل من كال يكيل أو شبهه من الفعل فالاسم منه مكسور ، و المصدر مفتوح من ذلك مال مميلاً وممالاً تذهب بالكسر إلى الأسماء ، وبالفتح إلى المصادر " .

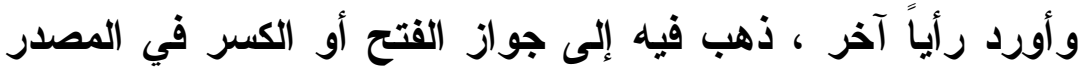

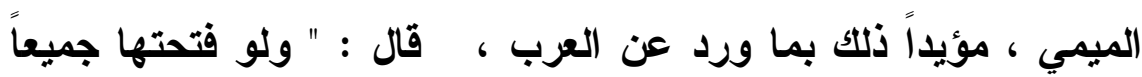
أو كسرتهما في المصدر والاسم لجاز ، تقول العرب : المعَاث ، وقد قالوا : المعيش ، وقال رؤبة بن العجاج :

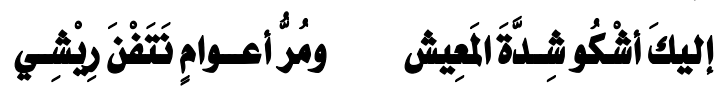

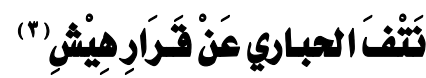

ومثله مستار ، وما كان يشبهه فهو مثله " (؟).

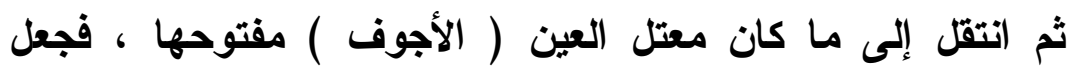

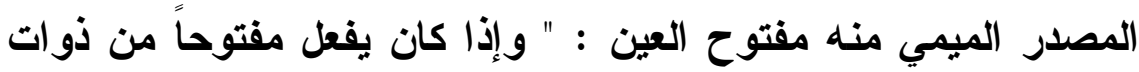
الياء و الو او مثل : يخاف ويهاب فالاسم و المصدر منه مفتوحان مثل : المخَاف و المهَّاب "، ثم ذكر ما كان من الواو مضموماً مثل يقول ويعود

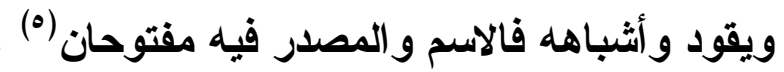

$$
\begin{aligned}
& \text { (1) سورة البقرة ، الآية : ( r r ) ). }
\end{aligned}
$$

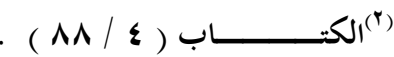

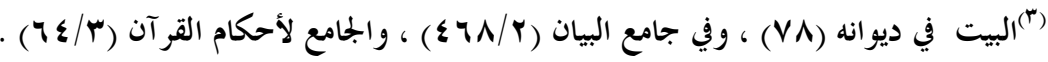

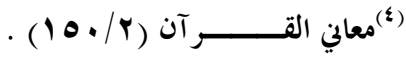

$$
\begin{aligned}
& \text { (•) المصدر السابق البق }
\end{aligned}
$$


أمَّا المبرّدّ فقد جعل الوجه في ذلك الفتح : " تقول في مفعل إذا أردت به مذهب الفعل من القول و البيع وما كان مثل واحد منهما ( مقَّال

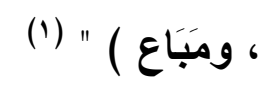

أمَّا (بن مالك فقد تحدث عن مصدر الأجوف اليائي فذكر ثلاثة آراء

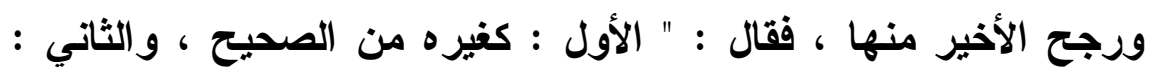

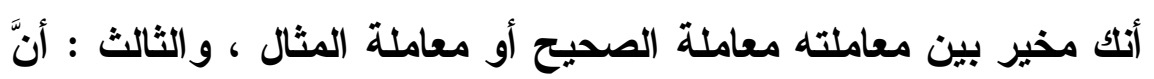

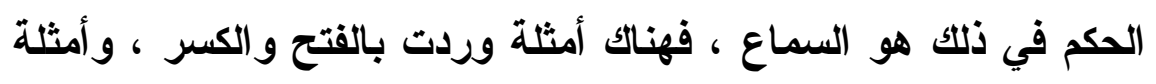

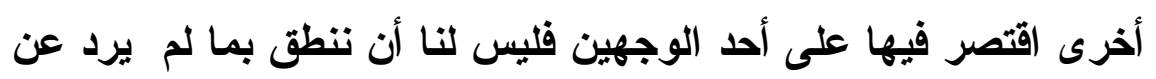

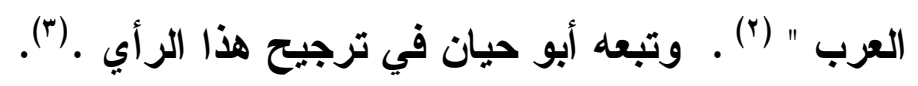

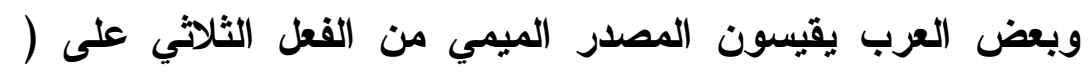

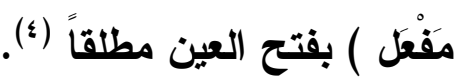

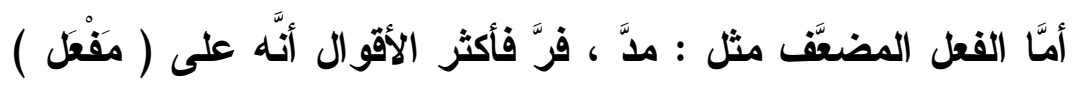

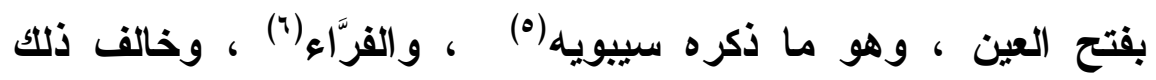

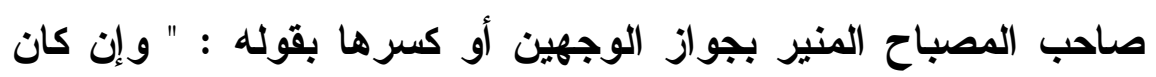
من ذوات التضعيف ، فالمصدر بالفتح والكسر معاً نحو : فرَّ مفََّّا ومفِرا (v) "

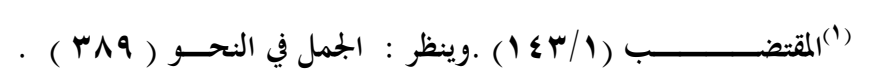

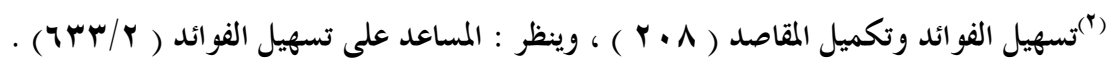

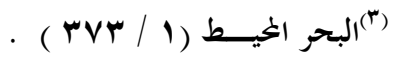

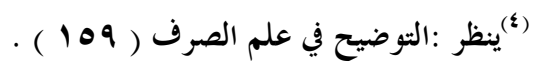

$$
\begin{aligned}
& \text { ( } \\
& \text { (؟) }
\end{aligned}
$$

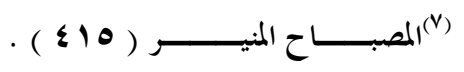




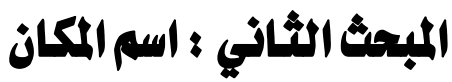

تعريفه : ذكر ابن الحاجب تعريفاً لاسم الزمان والمكان ، بقوله : " كـلـ

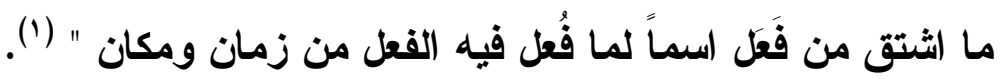

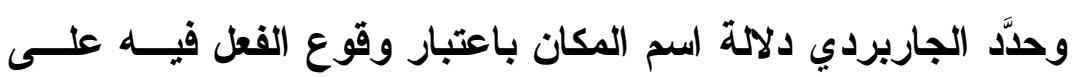

إطلاقه دون تقييد بمكان محدد فقال : " هي الأسماء الموضوعة للزمسـان لهان و المكان باعتبار وقوع الفعل مطلقاً ، أي من غير تقييد بمكان أو زمان ،

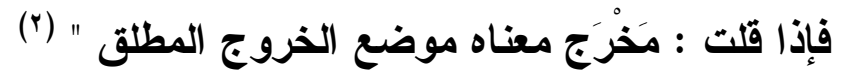

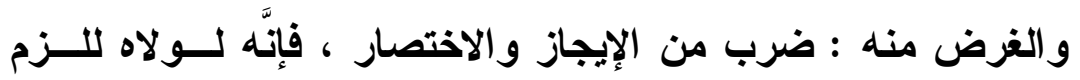
الإتيان بلفظ الفعل والمكان نحو : هذا المكان الأي قتل فيه زيد ، ققيـلـ

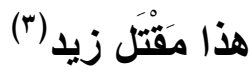
ا-_ صوغه من الفعل الصحيح : أ - إن كان مفتوح العين في المضارع :

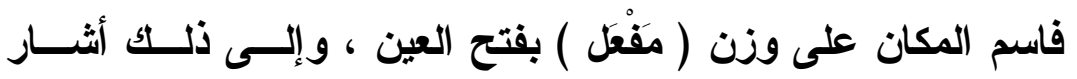

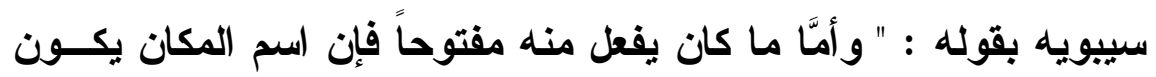

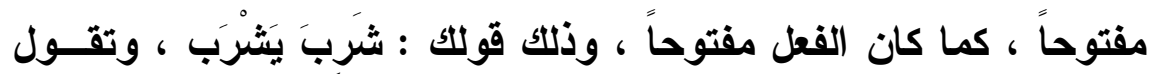

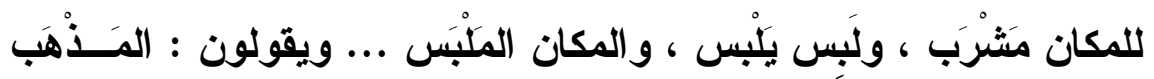

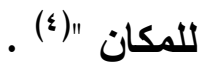

$$
\text { (1) (1) }
$$

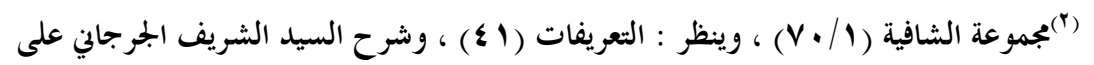

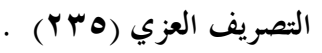

$$
\begin{aligned}
& \text { (") }
\end{aligned}
$$

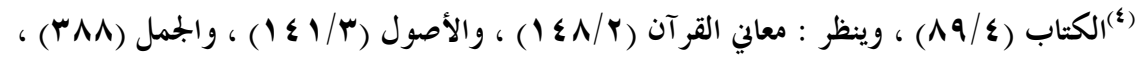

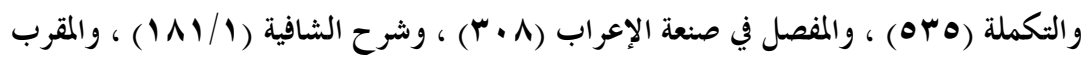


ب - إن كان الصحيح مضموم العين في المضارع :

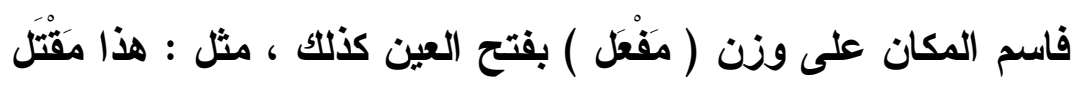

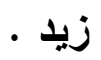

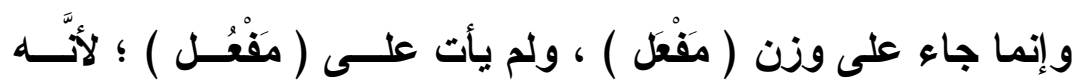

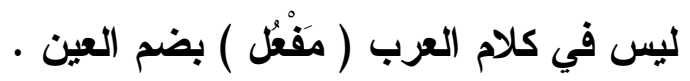

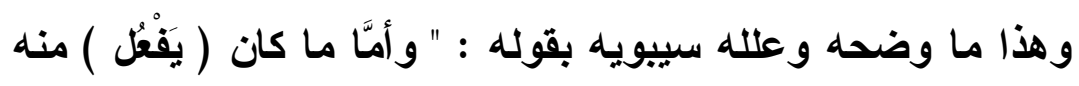

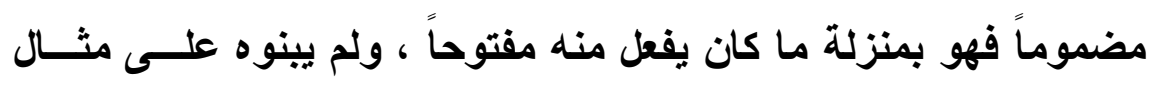

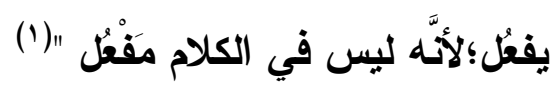

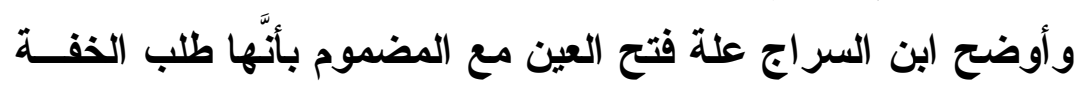

بالفتحة (ץ) وعلل الرضي الفتح في مضموم العين بنــدور ضــــم العـين فكـان

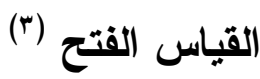
ج - إذا كان الصحيح مكسور العين في المضارع :

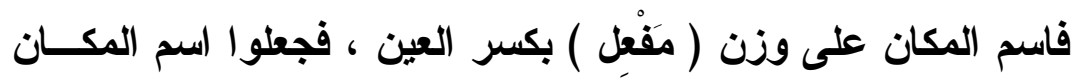
على بناء الفعل .

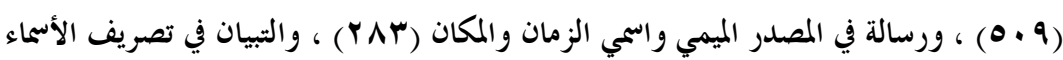
- ( $\bullet \bullet$

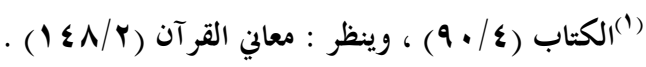

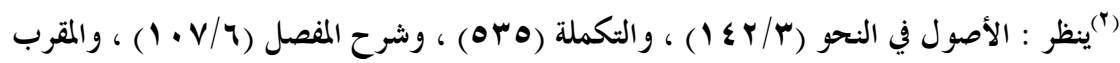

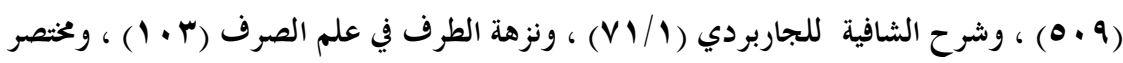

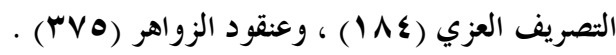

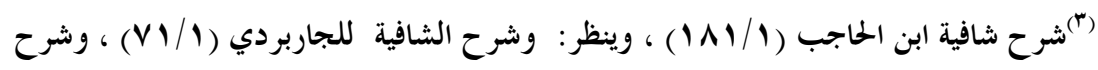
مختصر التصريف العزي (عـ1^) 


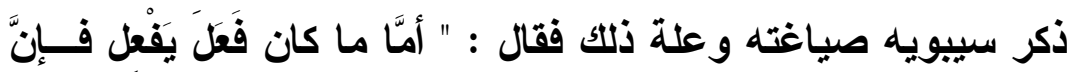

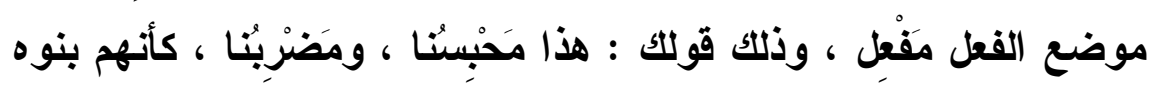

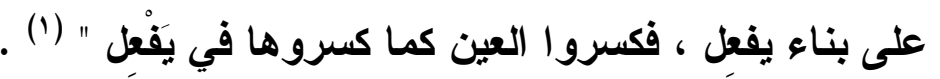

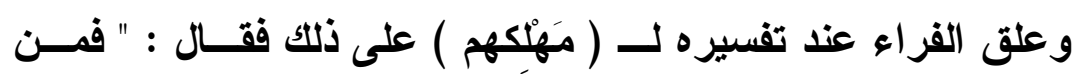

أراد الاسم مما يفعل منه مكسور العين كسر مفعلاً " (؟).

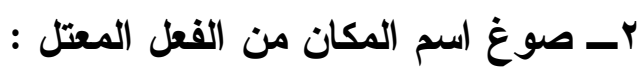

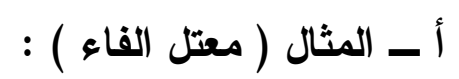

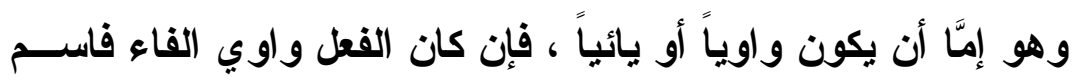

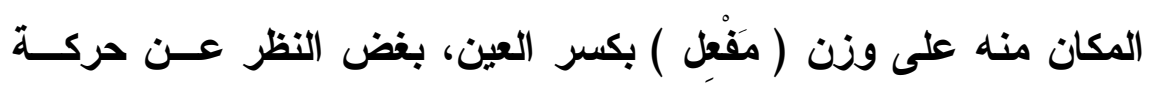

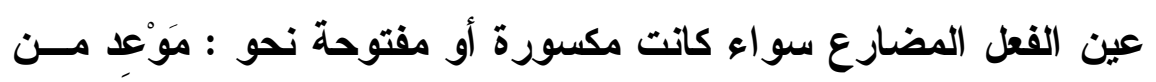
وعََ يعِد ومَوْضِعِ من وضعَ يَضَعَعُ .

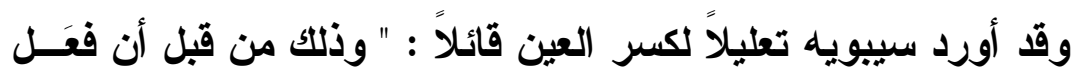

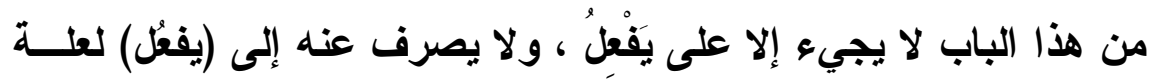

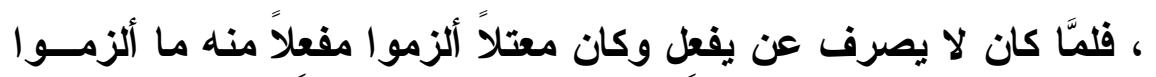
يَفْعِل ، وكر هوا أن يجعلوه بمنزلة ما ليس بمعتل " (").

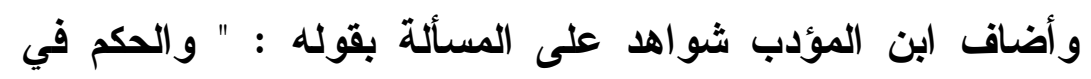

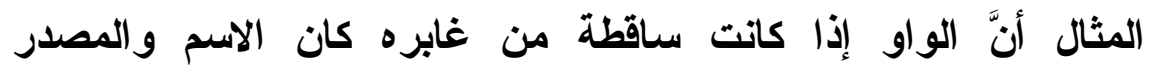

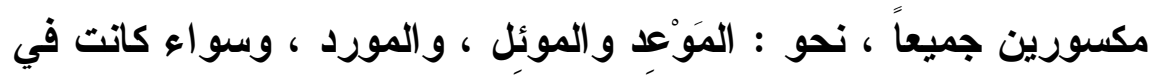

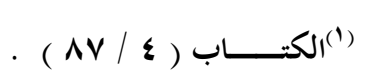

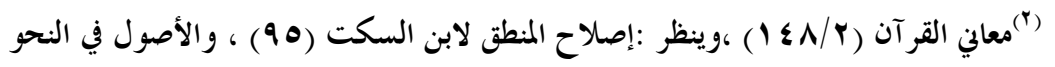

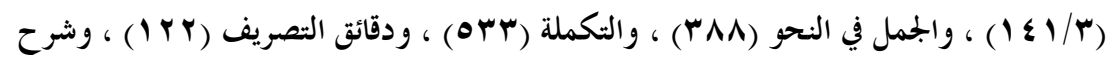
المفصل (ז/ + +1) .

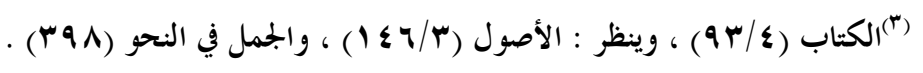


الفعل منصوبة أو مكسورة بعد أن تكون الواو منه ساقطة ، قال تعالى :

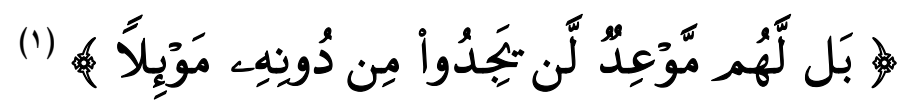

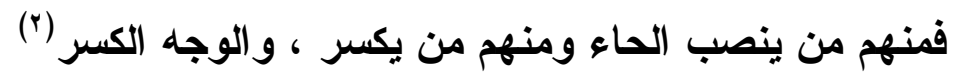

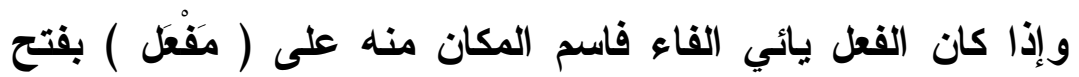

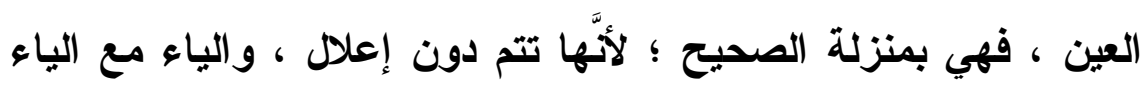
أخف في النطق ،

قال الرضي :"و المثال اليائي بمنزلة الصحيح عندهم ؛ لخفته ، تقول في يَيَفَظ مَيَفَظ في المصدر والزمان والمكان ، ومنه قوله تعالى :

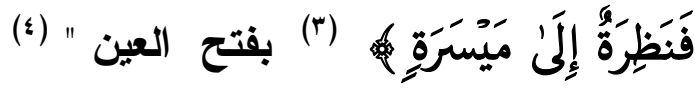

$$
\begin{aligned}
& \text { ب ـ الأجوف ( معتل العين ) : }
\end{aligned}
$$

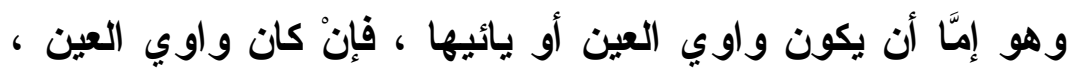

سو اء كانت العين مفتوحة أو مضمومة ، فللصرفيين في ذلتك رأيان :

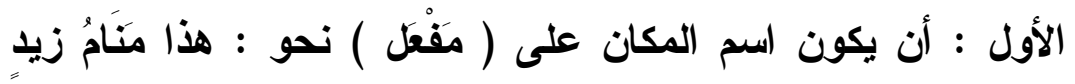

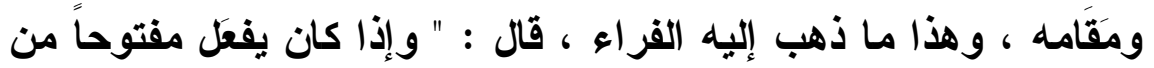

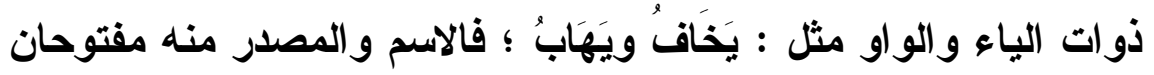
مثل : المَخَاف و المَهَاب " ثم ذكر المضموم وحكمه : " وما كان من الواو

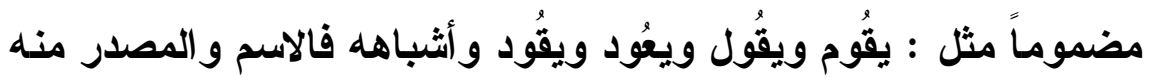

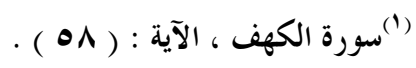

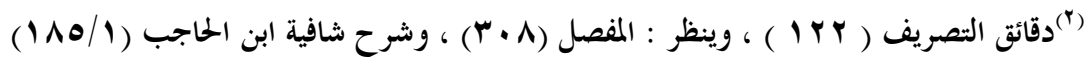

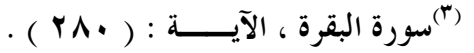

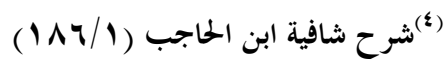




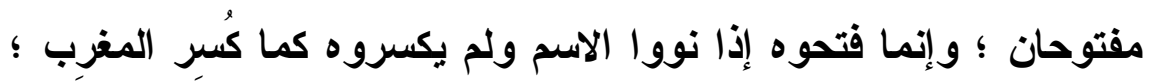

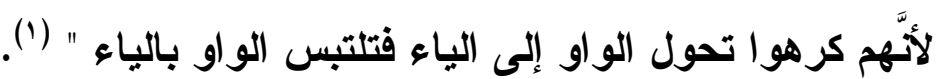

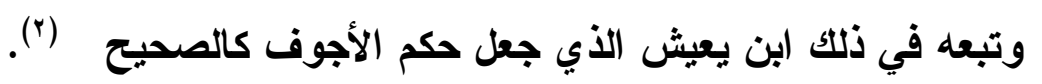

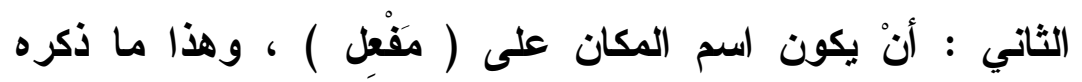

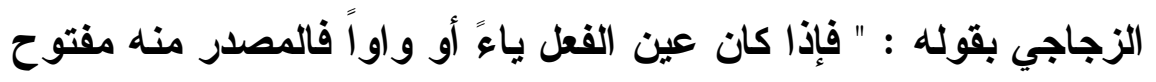

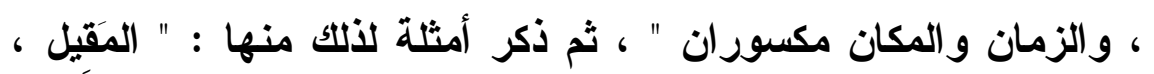

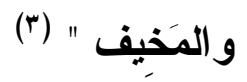

ولم أجد أحاً من الصرفيين قد ذهب إلى رأي الزجاجي .

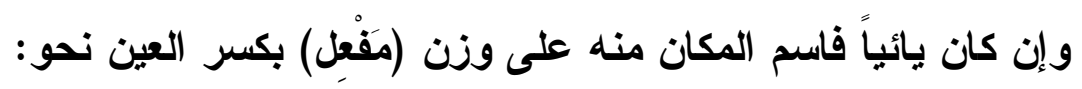

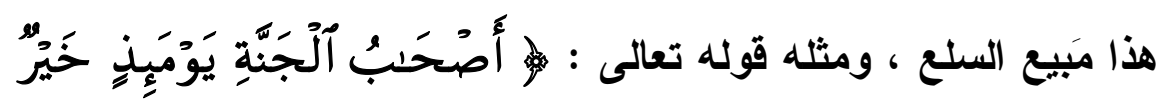

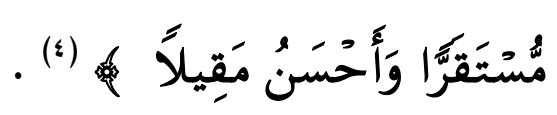

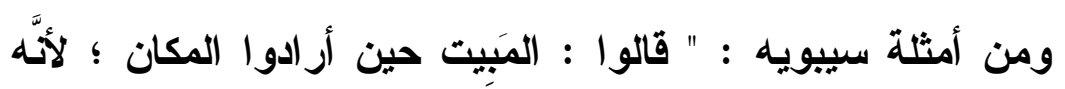

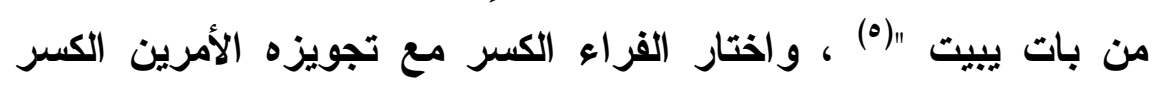

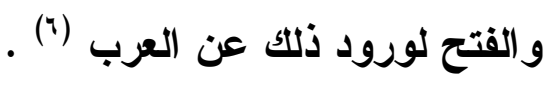

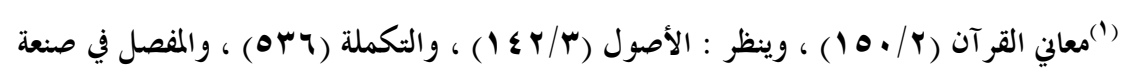

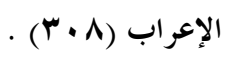

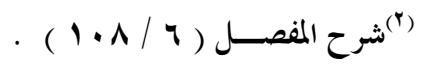

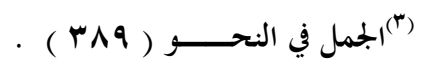

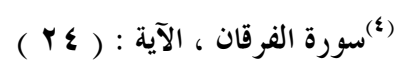

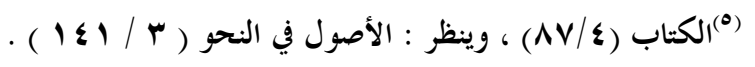

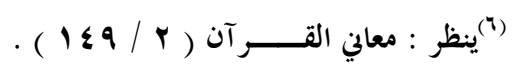

$$
\begin{aligned}
& --1999--
\end{aligned}
$$


وجعله ابن يعيش كالصحيح المكسور العين : " وما كان مكسور

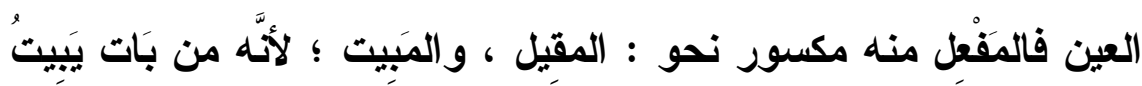

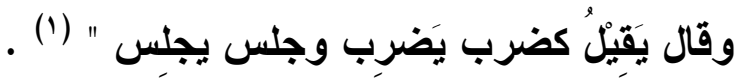

ج - الناقص ( معتل اللام ) :

يشتق اسم المكان منه على وزن ( مَفْعل ) بفتح العين ، ولا يختلف

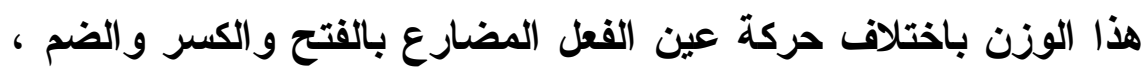

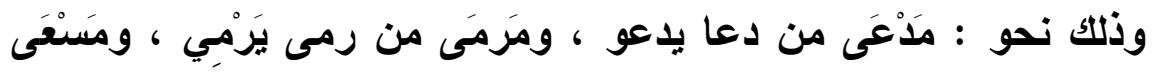
من سعى يَنْعَى ، ومن أمثلة ذلك ما ورد في كتاب الله عز وجل :

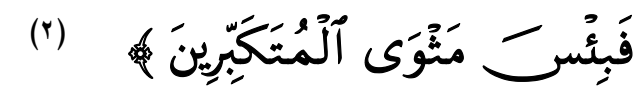
وقد بيَّن سيبويه علة فتح العين بقوله : " وذلك لأنَّه معتل ، وكأن

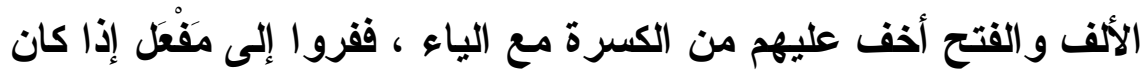
مما يبنى عليه المكان "(r) .

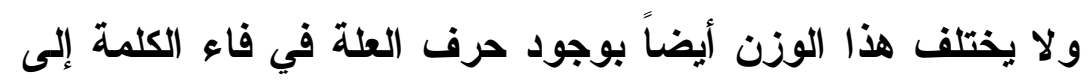

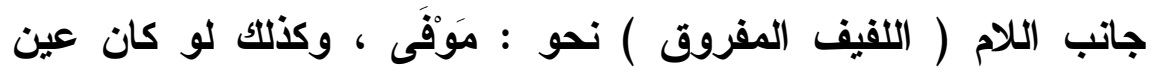

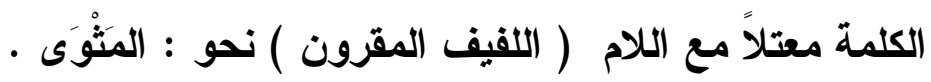

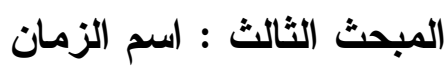

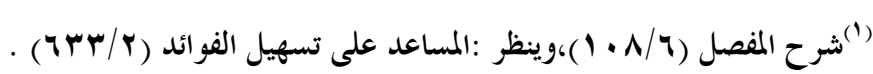

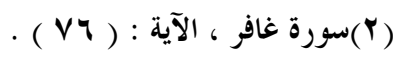

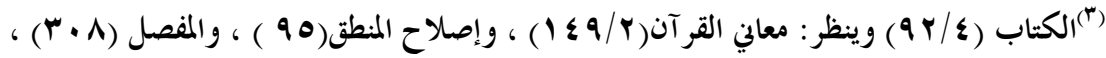

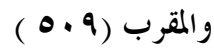


تعريف اسم الزمان : اسم الزمان مشتق مبلوء بميم زائدة ، يدل علـى

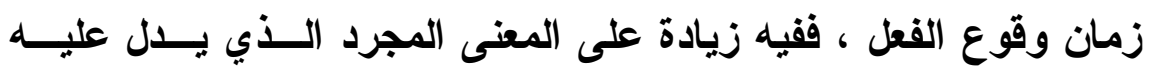

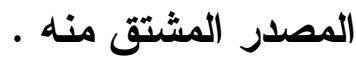

و الغرض منه : ضرب من الإيجاز و الاختصار ، فإنَّهَه لــولاه للــزم

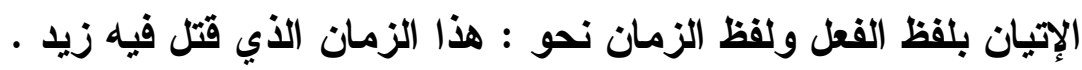
ـ صيغ اسم الزمان القياسية : يصاغ اسم الزمان كما يصاغ اسم المكان ، سواء من مصدر الثلألــي

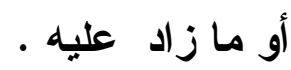
صوغه من الثثلاثي : ( ) صوغه من مصدر الفعل الصحيح :

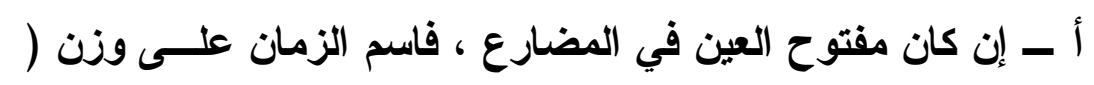

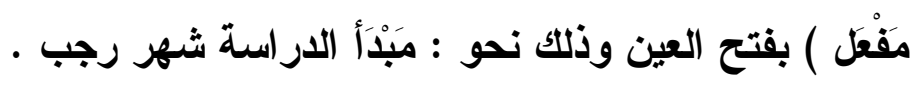

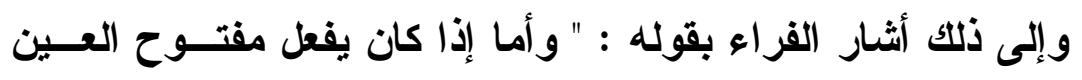

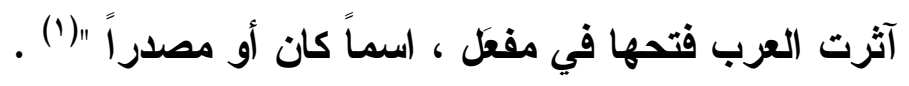

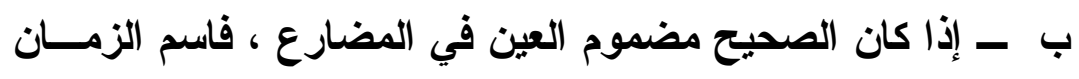

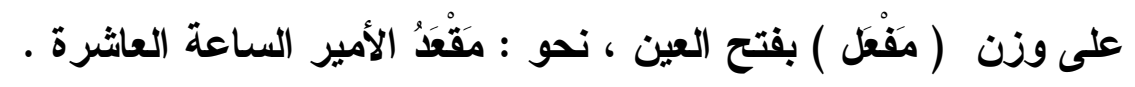

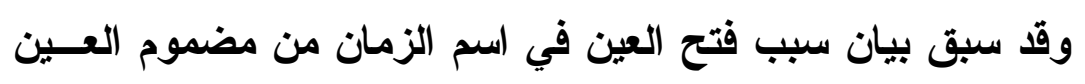

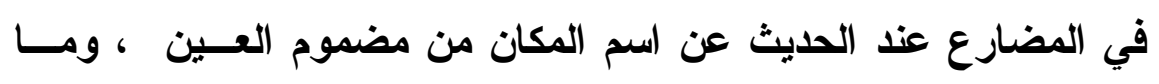
ذكره الصرفيون في ذلتك . مئل

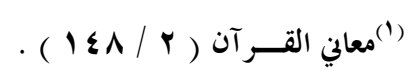


ج - إذا كان الصحيح مكسور العين في المضارع فاســم الزمـــان

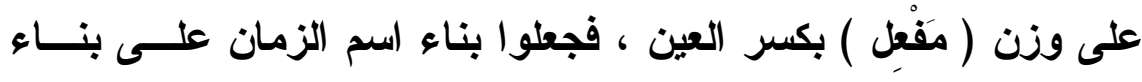
(الفعل . (اعل ونان

و إلى ذلك أثثار سيبويه بقوله : " وقث يجيء المفعل يراد به الحـين

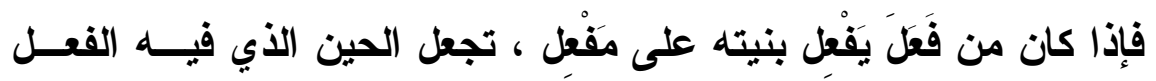

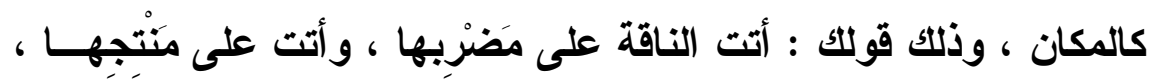

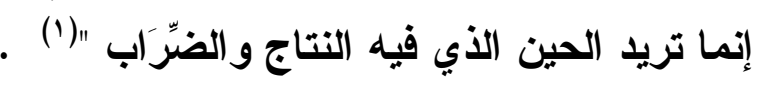

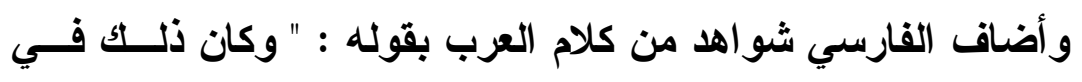

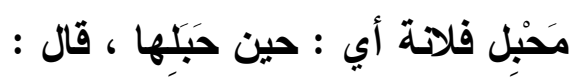

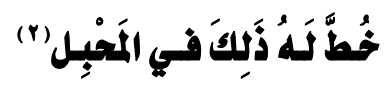

r إم صوغ اسم الزمان من مصدر الفعل المعتل :

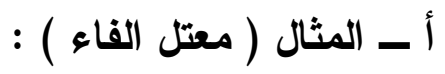

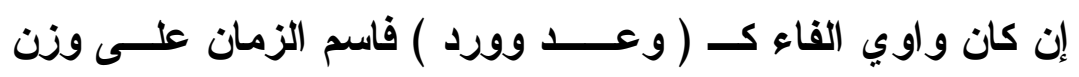

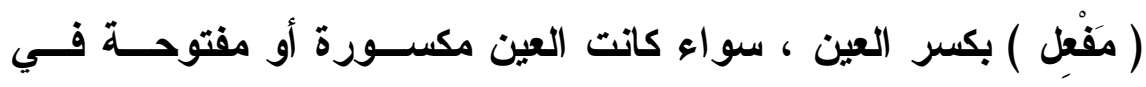

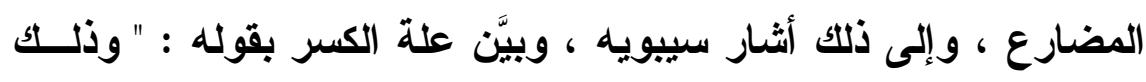

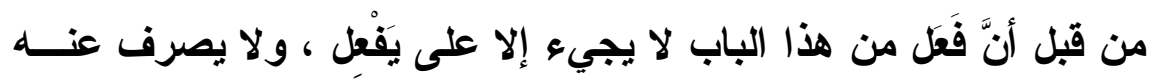

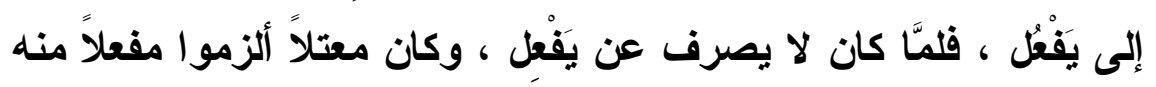

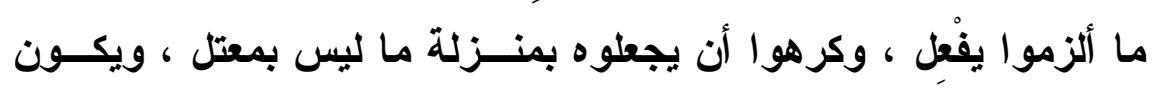

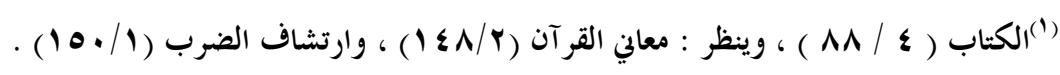

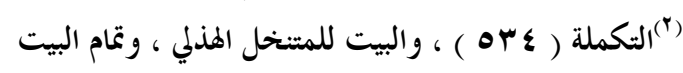

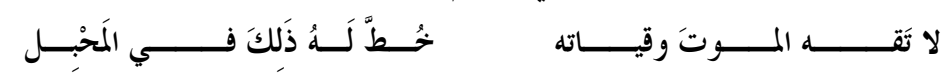
والبيت في ديوان الهذليين القسم الثاني (ع ( ) ، واللسان مادة ( هبل ) ، وتاج العروس مادة ( حبل ) 


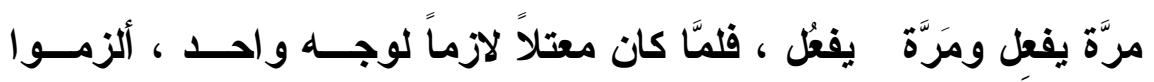

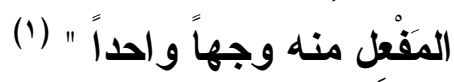

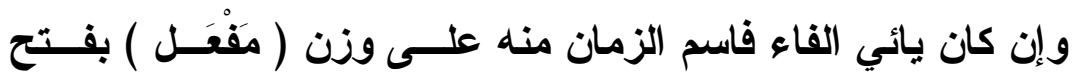

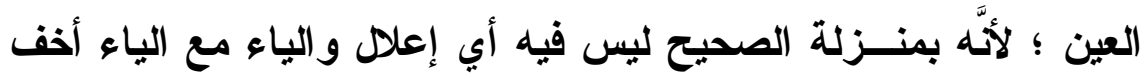

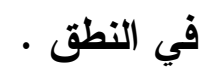

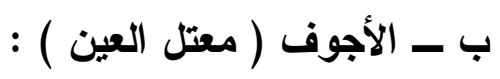

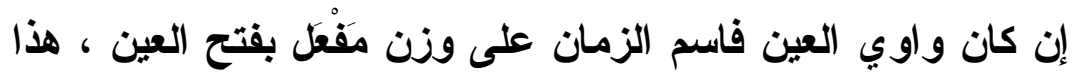

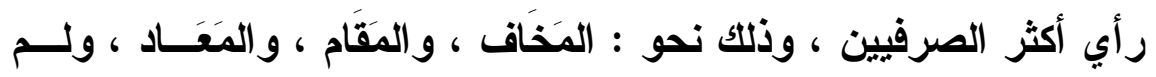

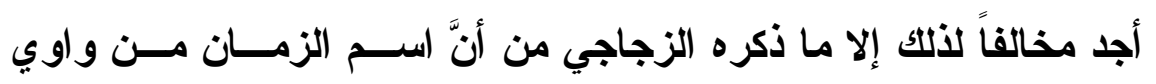

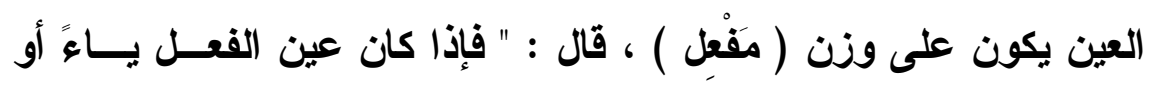

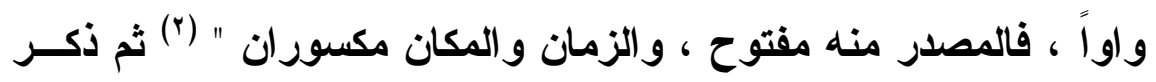

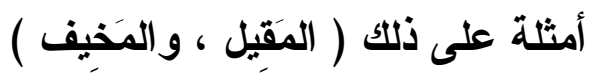

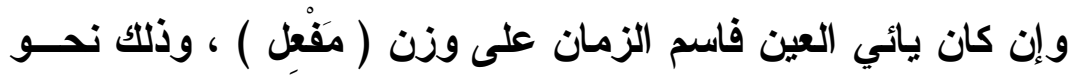

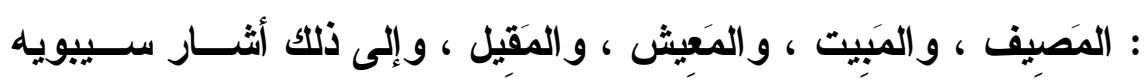

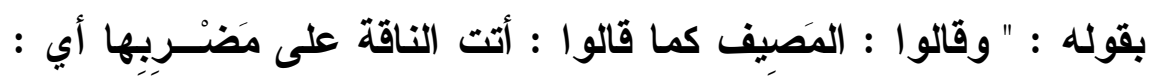
على زمان ضِرَابِها " ("). ومثل له الفراء بقوله : " إذا كان المَفْعَل من كال يكيل وشبهها مسن

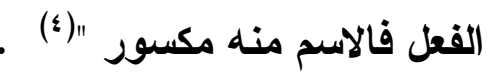

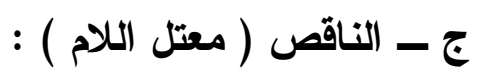

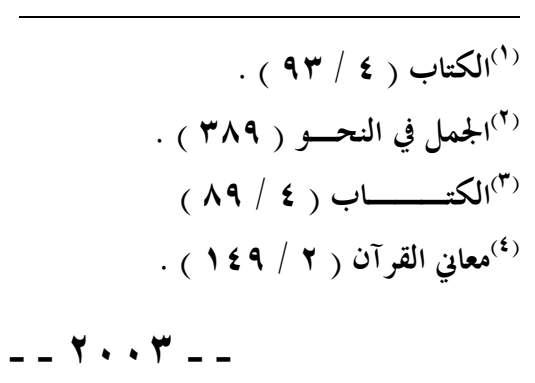


ويكون اسم الزمان منه على وزن (مَفْكل) بفتح العين ، سواءً كاتت

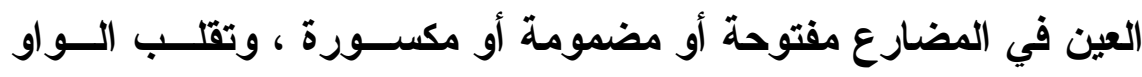

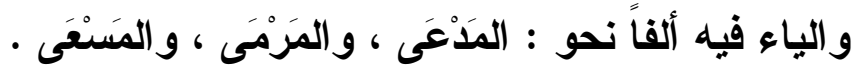

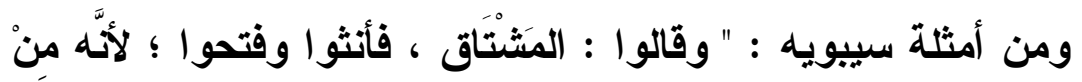

يَفْعُل " (1)

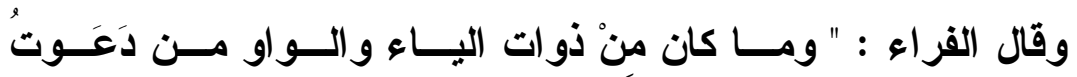

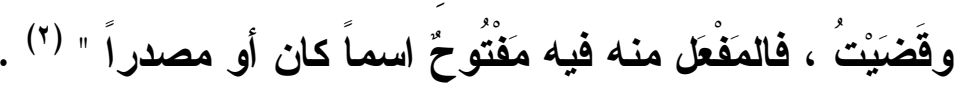




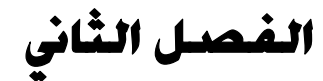

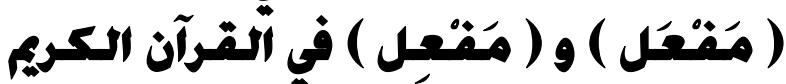

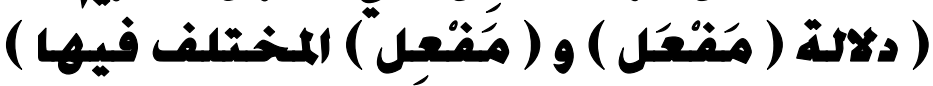

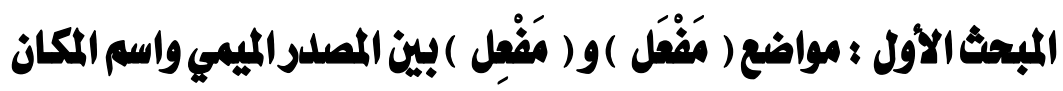

\section{مَاْهَن}

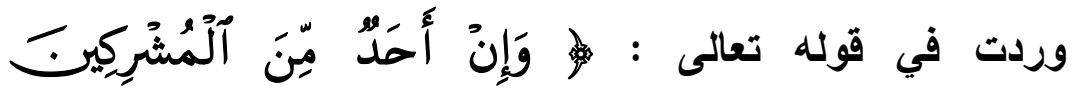

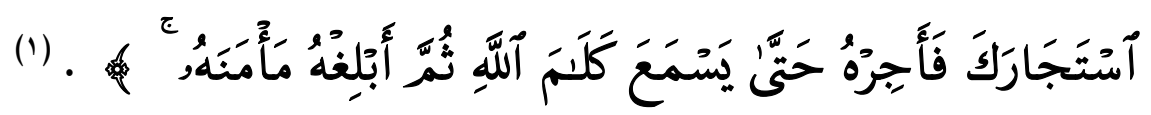
وهي من الأمن أو الأمسان ، يقال : أَمِن يَأْمَن أَمْنَاً وأمَانَاً ، وأصل

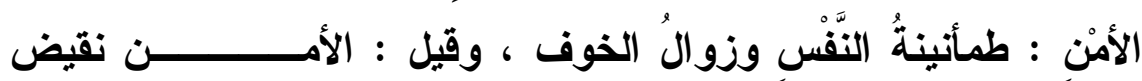

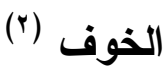

وللمفسرين في تفسير لفظة " مَأْمَن " قولان :

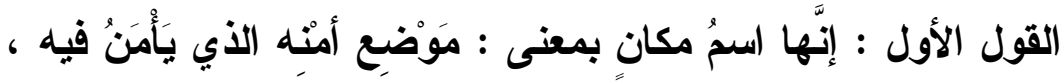

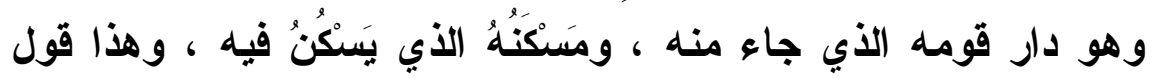
أكثر المفسرين ، و والصرفين لمدين

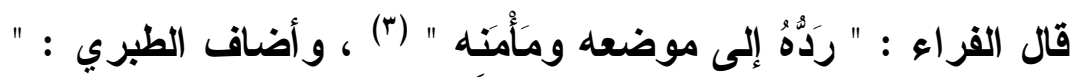
إلى حيث يأمن منك وممن في طاعتك حتى يلحق باراره وقومه من

$$
\begin{aligned}
& \text { (1) سورة التوبة ، الآية : ( } 7 \text { ( ) . }
\end{aligned}
$$

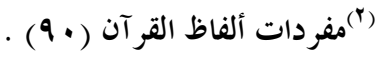

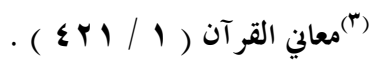




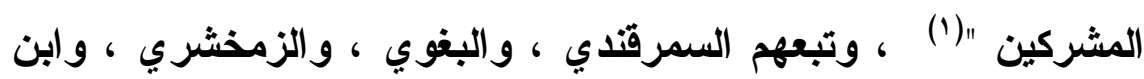

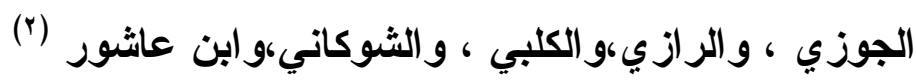

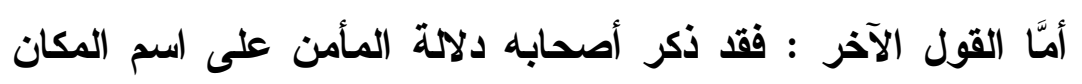

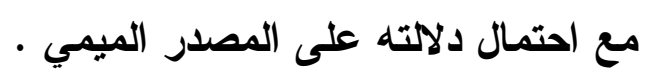

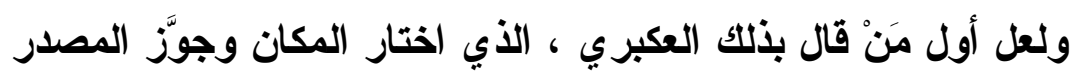

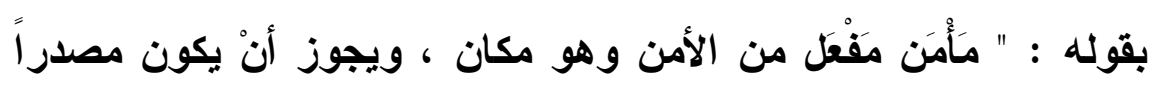

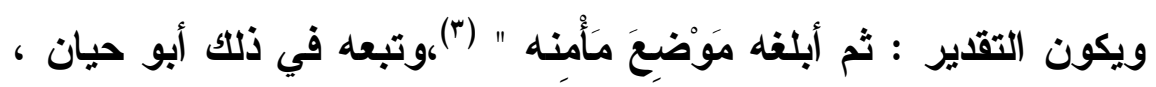

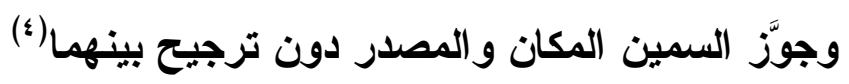
وعلق الثهاب الذفاجي على كلام البيضاوي الذي قال فيه : " "

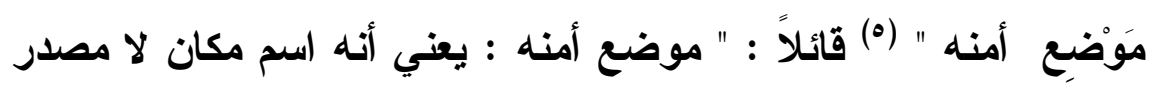

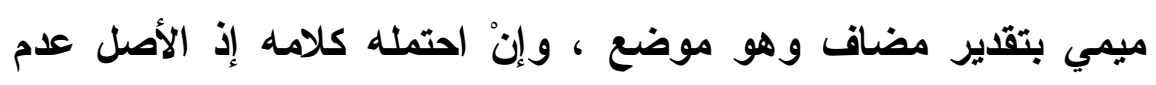
التقدير " (") ميفي ل)

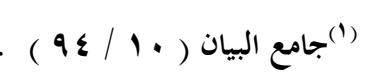

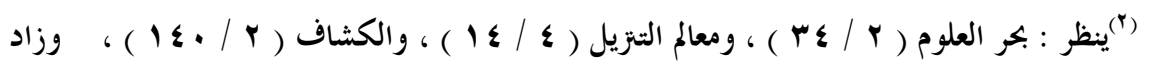

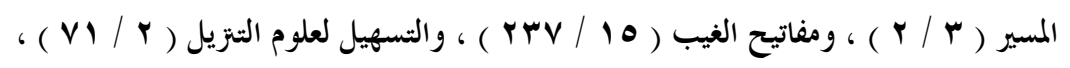

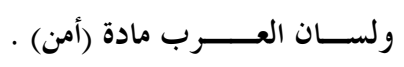

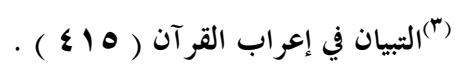

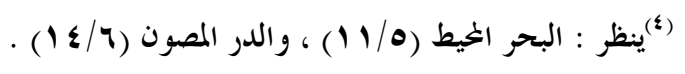
(0)

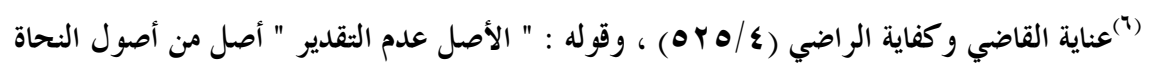

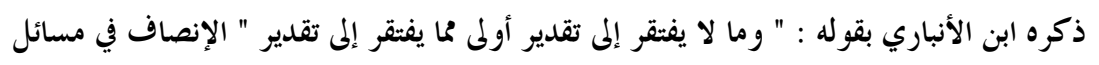

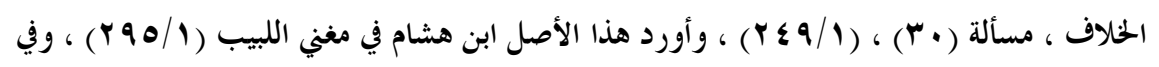

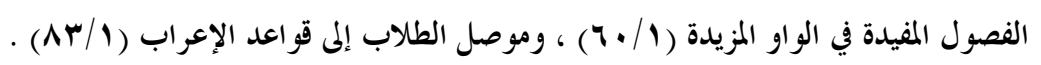


وحظي رأي الثهاب بتأييد من الألوسي ، حيث رجح اسم المكان ؛

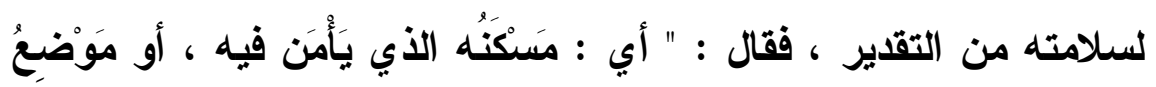

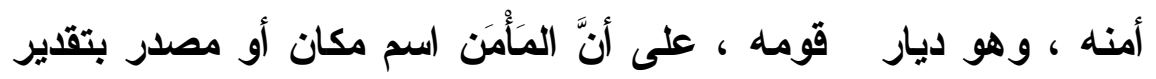

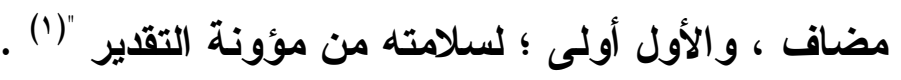
ويبدو لي بعد عرض تلك الأقو ال ترجيح اسم المكان ، وذلك :

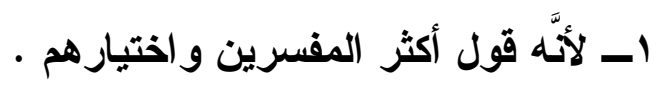

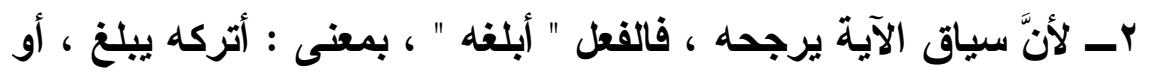

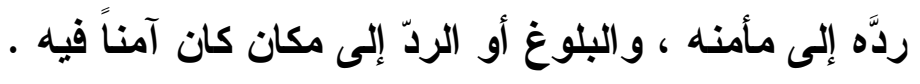

\section{مَبْلَغ}

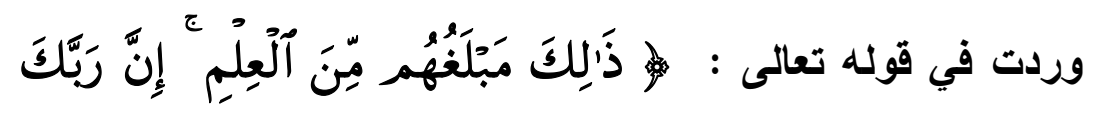

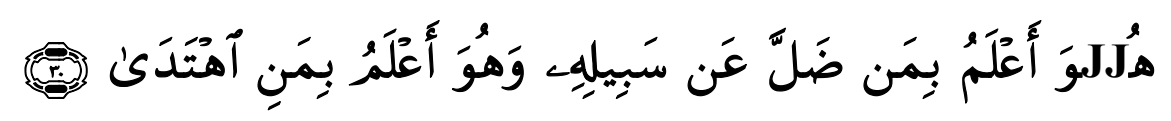
(r)

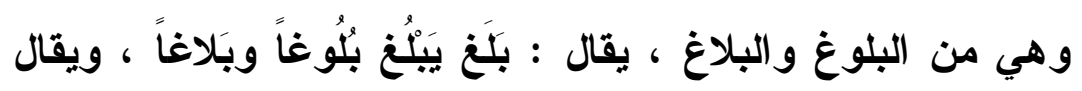

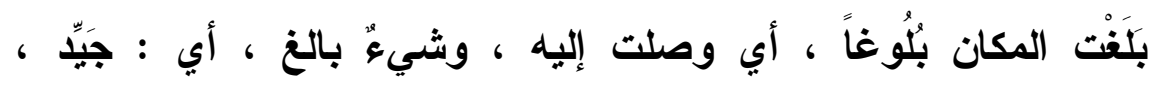

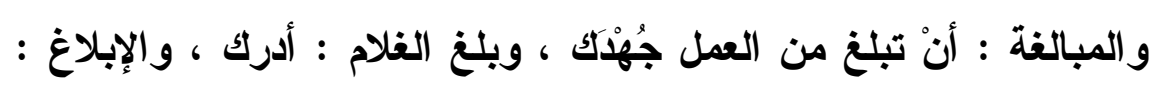

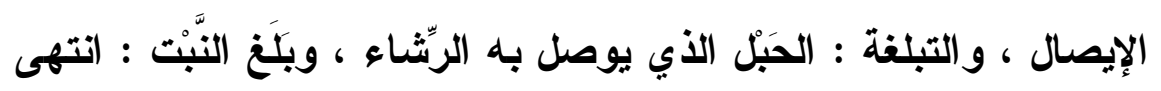

$$
\text { (1) }
$$

("بنظر : الصحاح مادة (بلغ) ، ولسان العرب مادة (بلغ) ، وتاج العروس مادة (بلغ ) . 
أورد المفسرون ثُلاثة آراء في تفسير الــ ( مَبَْغ ) في الآية :

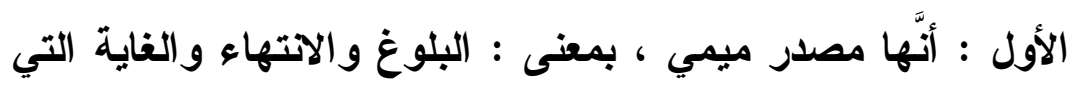

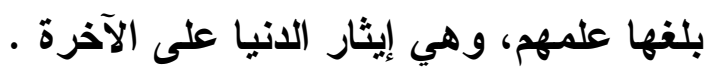

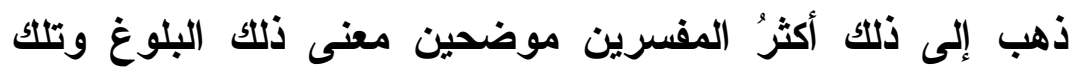
النهاية التي انتهى إليها تفكيرهم .

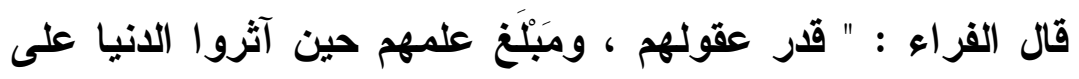
الآخرة "( المال

وزاد أبو حيان : " مبلغهم : غايتهم ومنتهاهم من العلم ، وهو ما باليا

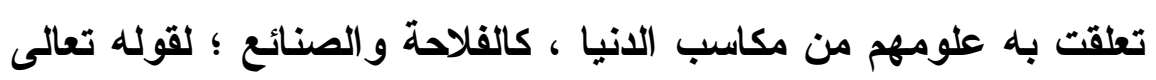

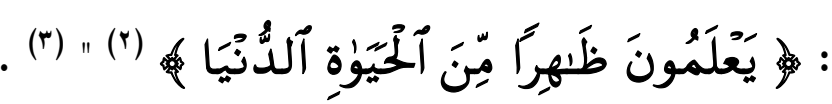

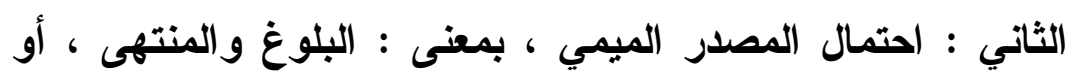

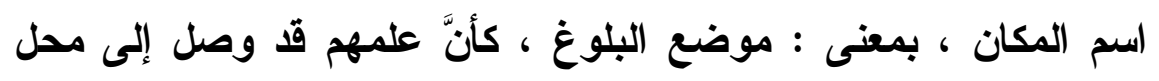

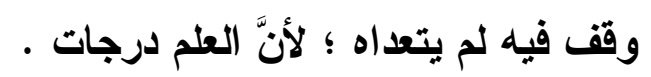
ذكر ذلك البقاعي بقوله : " أي : نهاية بلوغهم وموضع بلوغ لوغهم ،

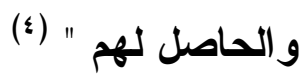

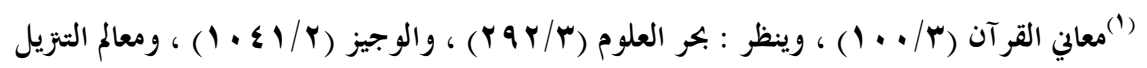

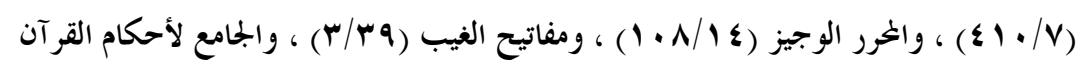

$$
\begin{aligned}
& \text {. (1.0//V) }
\end{aligned}
$$

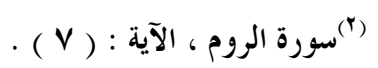

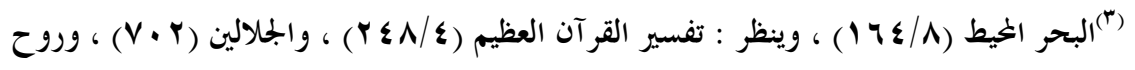

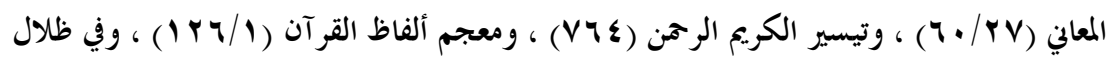

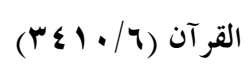

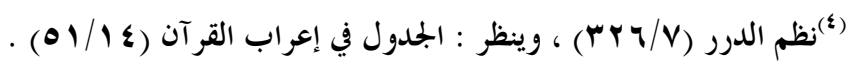




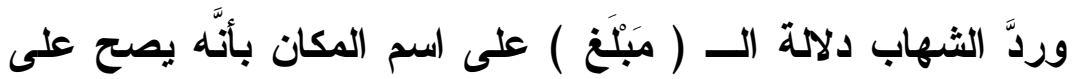

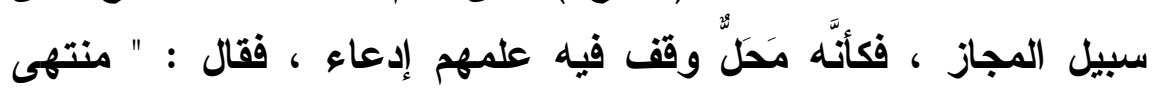
علمهم لا علم لهم فوقه ؛ لالالة البلوغ على الانتهاء ، وليس فيه فيه إثشارة

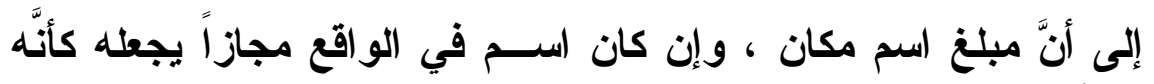

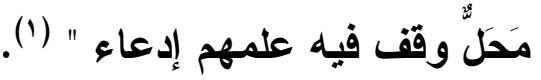

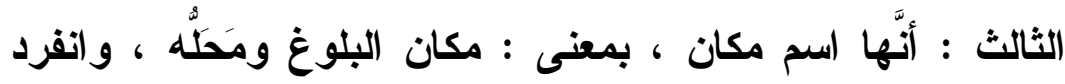

بذلك القاسمي (`).

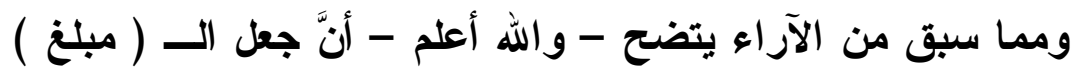

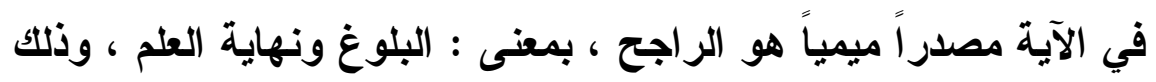

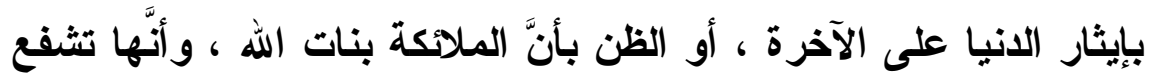
لهم ؛ وذلك : لانيار

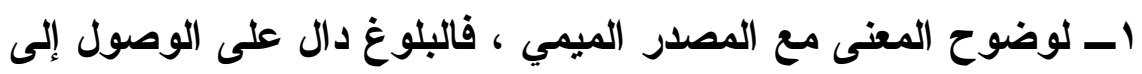

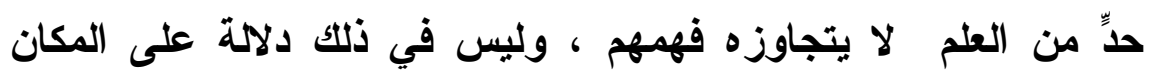
حقيقة . r- لأنَّ أكثر المفسرين قد أخذو ا به .

\section{مَطْلِع}

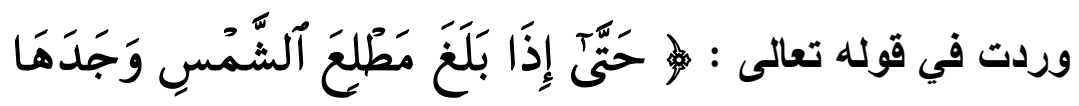

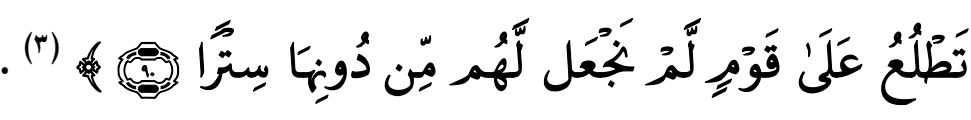

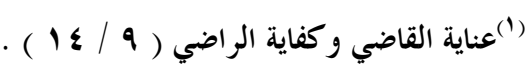

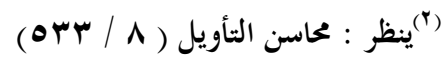

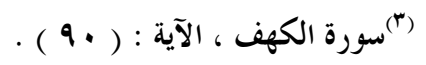


وهي على وزن ( مَفْعِل ) على قرَاءة الجمهور من الطلوع ، يقال :

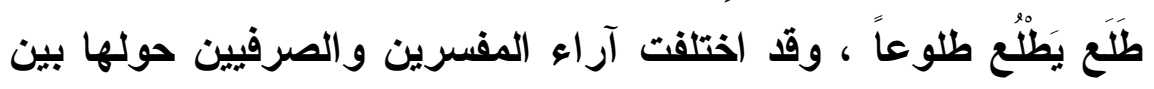

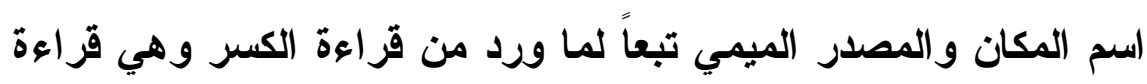

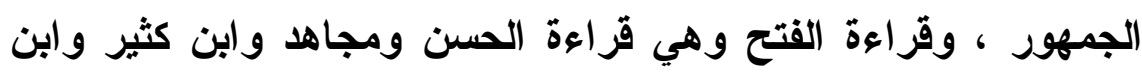

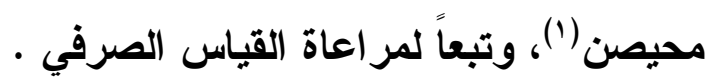

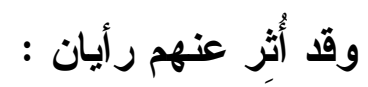

الرأي الأول : يرى أصحابه أنَّها اسم مكان بمعنى : موضع الطلوع : ألَّان

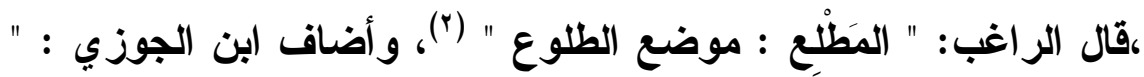

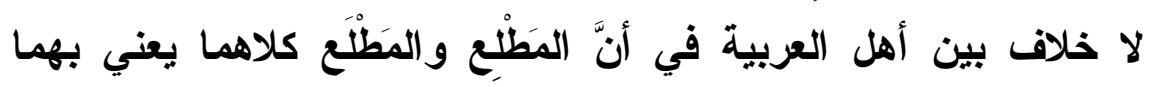

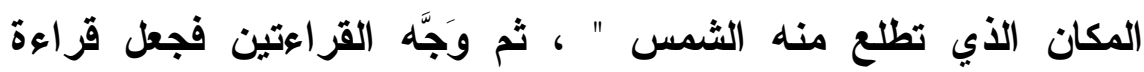

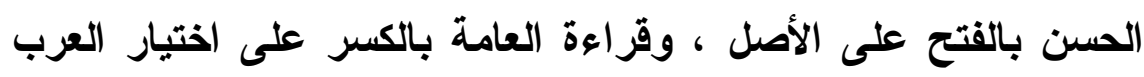

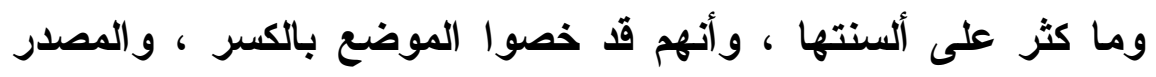
بالقتح (r)

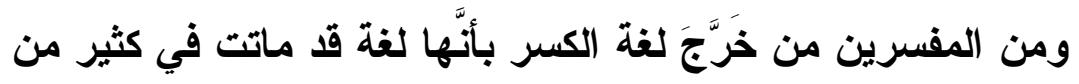

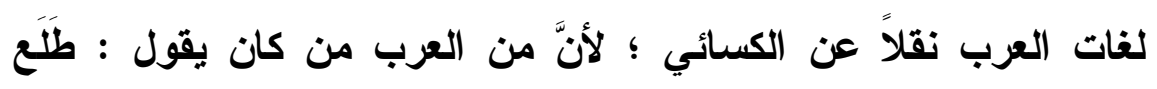

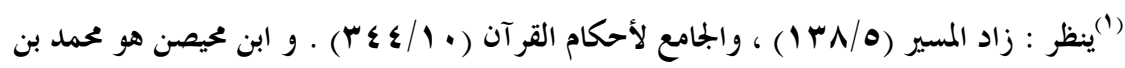

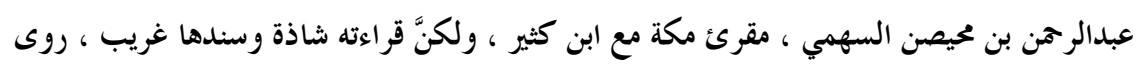

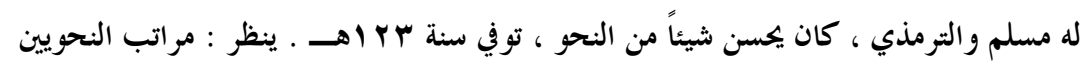

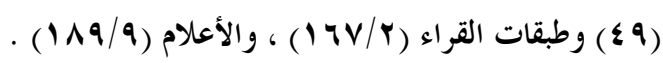

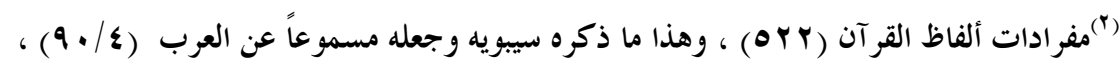

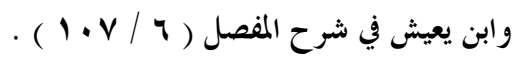

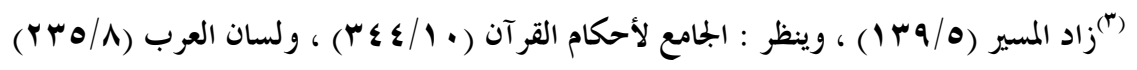


يَظْلِع بالكسر في المضارع ، ويقي مَظْلِع بكسر اللام في اسم المكان

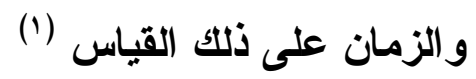

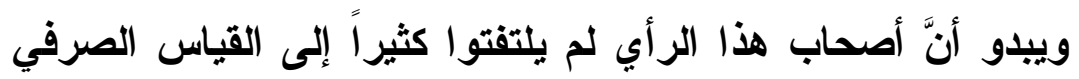

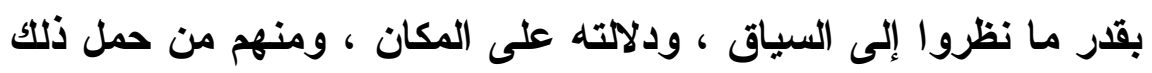

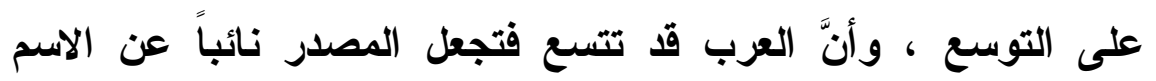

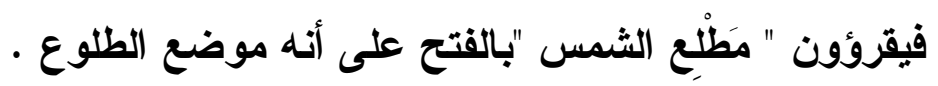

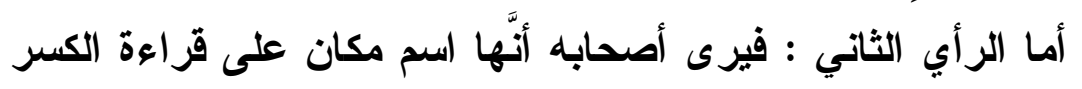
، و المعنى : موضع الطلوع ، ومصدر ميمي على قراعة الفتح ، ويكون

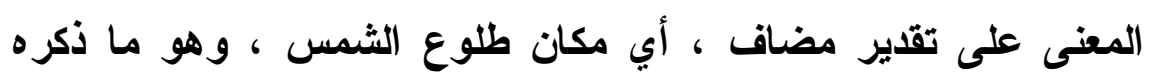

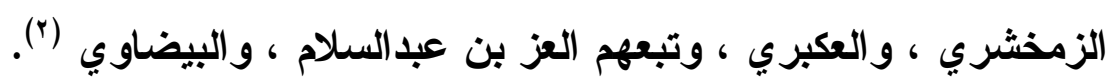
وعلق الثهاب على ما ذكره البيضاوي في قراعة الفتح ، فقال : "

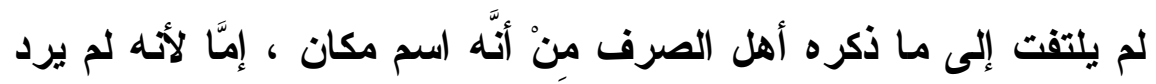

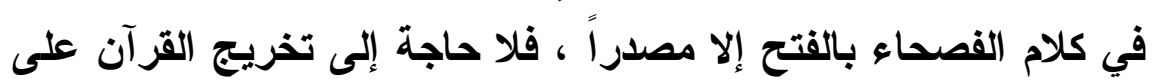

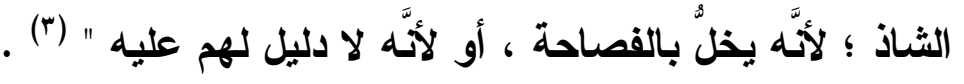

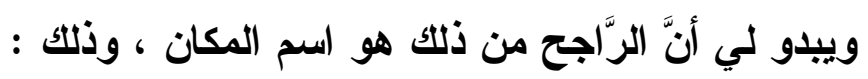

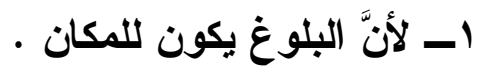

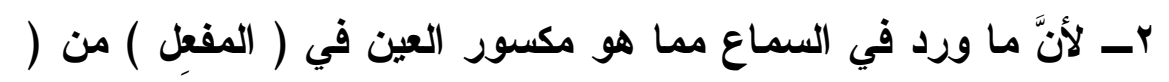

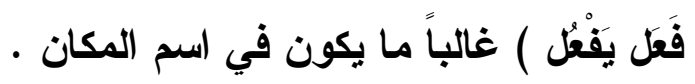

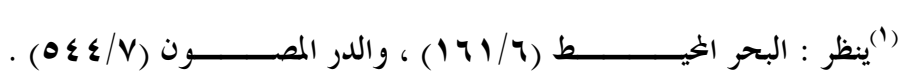

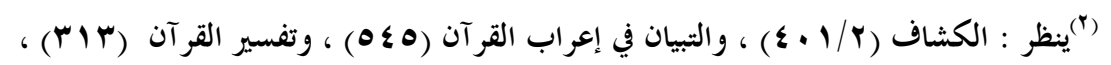

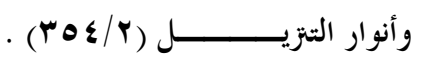

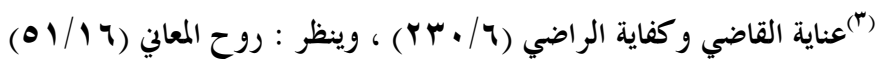


r- لأنَّ قراءة الجمهور بكسر اللام ( مَظْلع ) ، وقد اتفق المفسرون

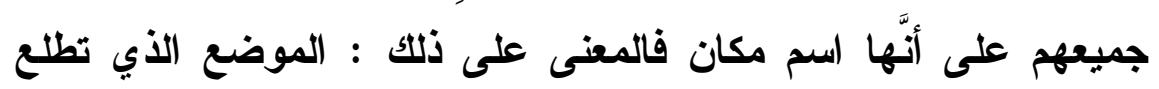

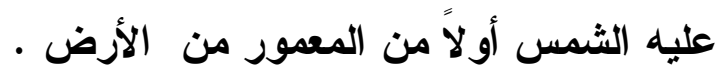

\section{مَوْعِد}

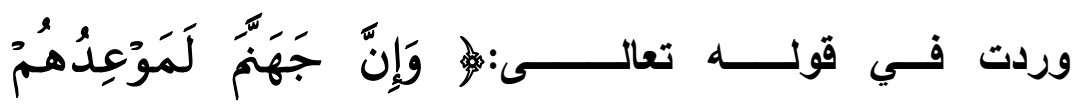

(1) أَجْمَعِينَ هُ

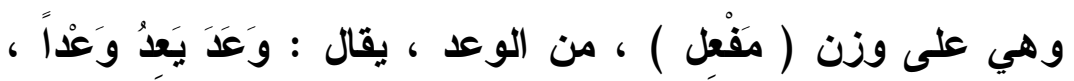

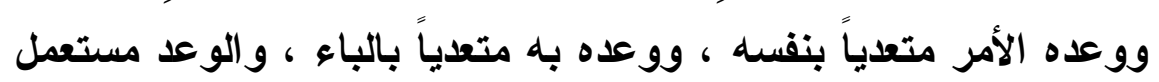

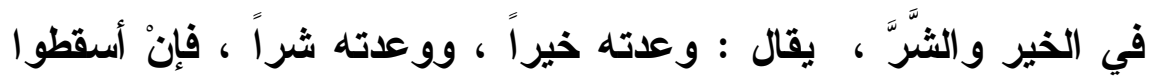

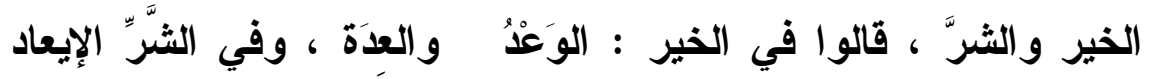

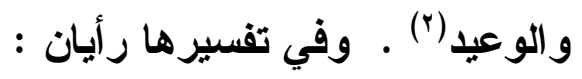

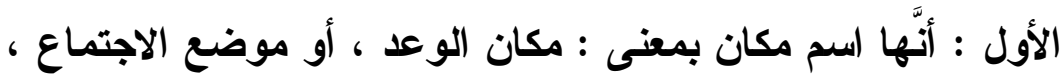

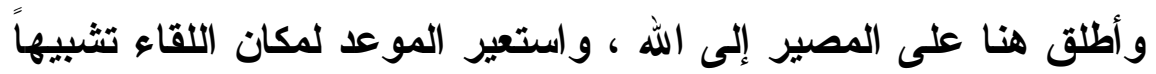

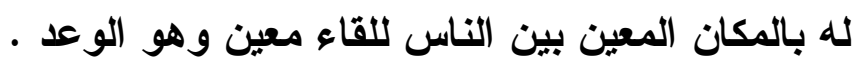

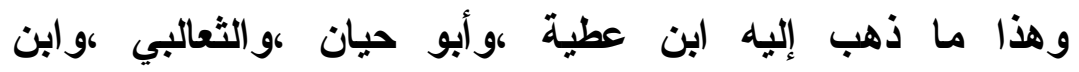

عاثشور (")

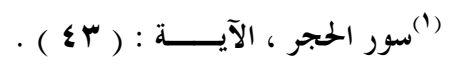

$$
\begin{aligned}
& \text { (Y)(بنظر : لسان العرب مادة (وعد)، وتاج العروس من جو اهر القاموس مادة (وعد) . }
\end{aligned}
$$

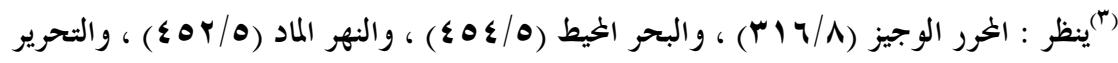

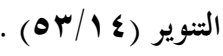


أمَّا الرأي الآخر فقد ربط أصحابه تفسير " المَوْعد " في الآية بالعمل

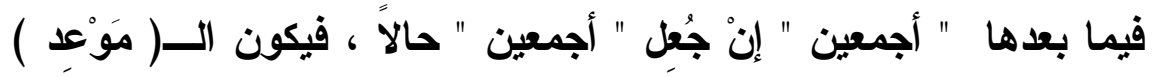

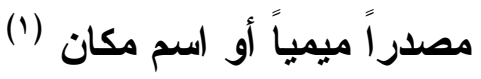
لأنَّ النحويين قد اثشترطوا في مجيء الحال من المضاف إليه كون

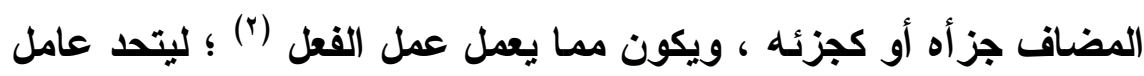
الحال وصاحبها ، وذلك متحقق في المصدر الميمي دون اسم المكان .

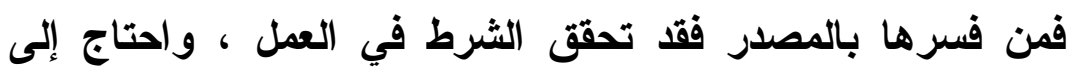

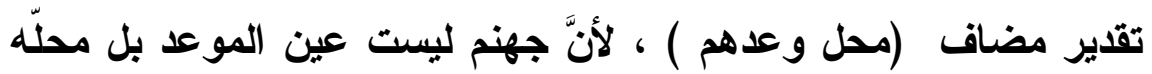

ومن فسرها باسم المكان ، جعل العامل في الحال معنى الإضافة وهذا ضعيف ؛ لأنَّ الإضافة من المعاني ، فلا تتصب الحال .

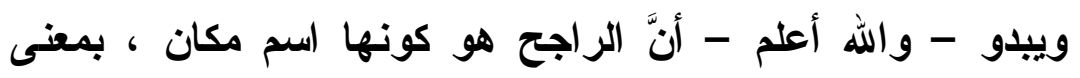
موضع اجتماعهم ، وذلك :

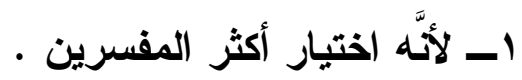

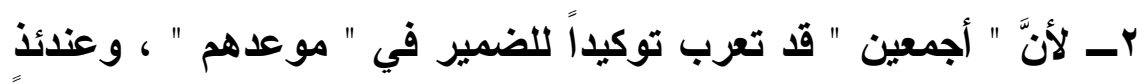

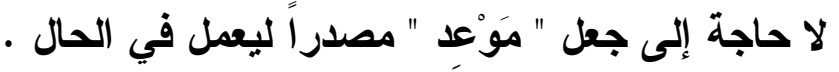

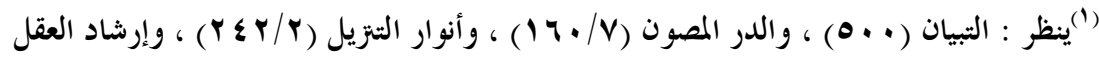

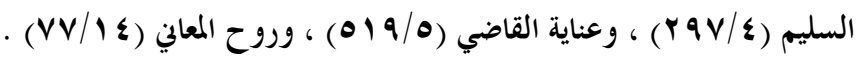

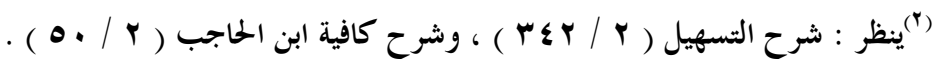




\section{المبحثَ الثاني : مواضع ( مَفْفَل ) و ( مَفْمِل ) بين المصدر الميهي واسم الزمان

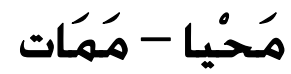

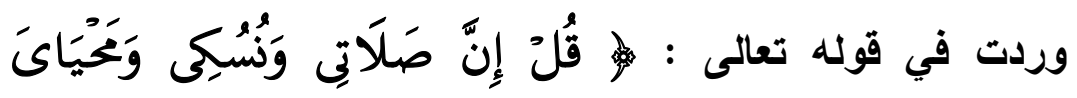

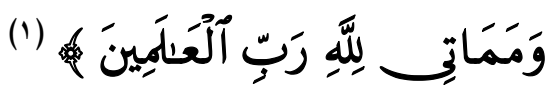

الــ ( مَحْيا ) مَفْعل من الحياة ، أصله ( مَحْيَيَّ ) ، تحركت الياء

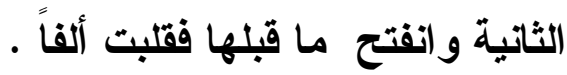

و الحياة ضد الموت ، والحيُّ ضد الميّّ ، حَيَّ يحيا ، وحَيَّ يَحْيَا

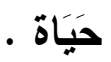

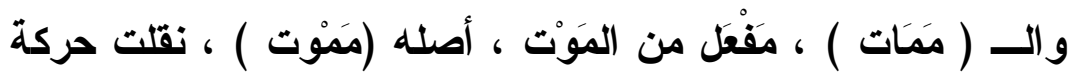

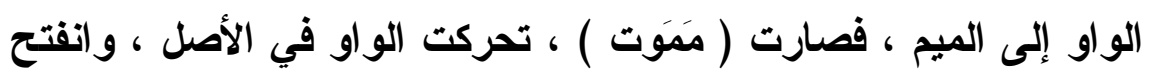

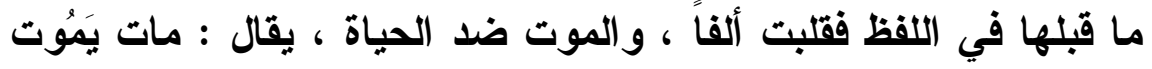

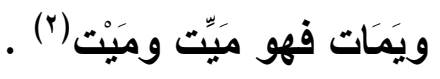

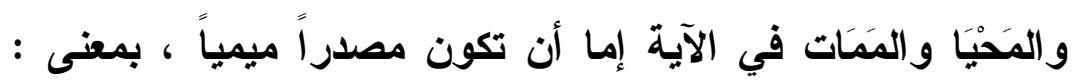

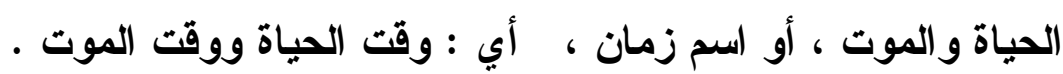

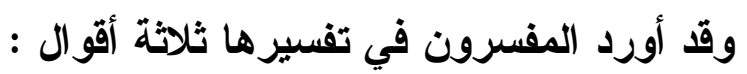

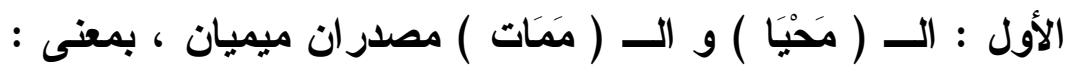

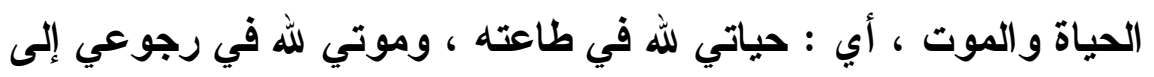

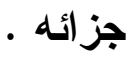

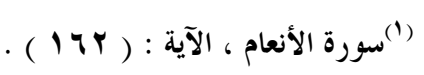

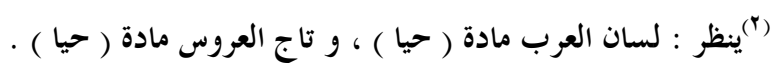


ذكر ذلك الطبري ، والبغوي ، وابن عطية ، وابن الجوزي ،

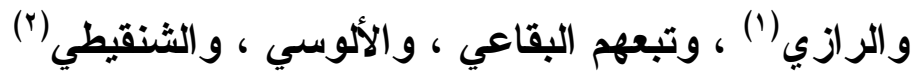

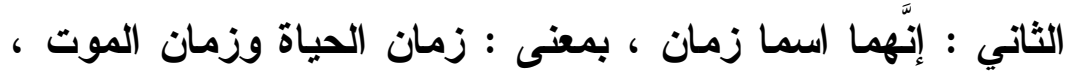

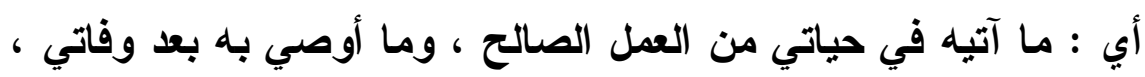

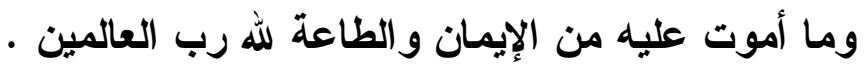

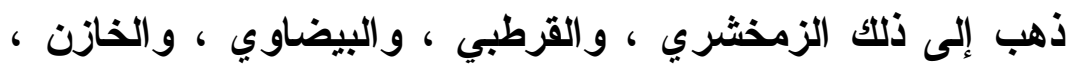

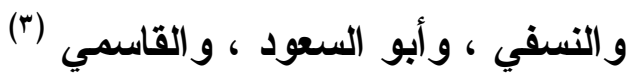

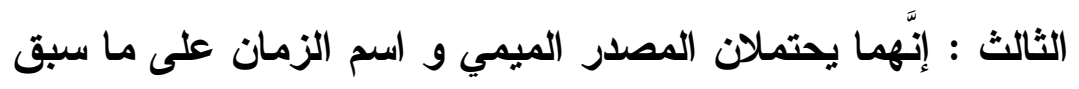

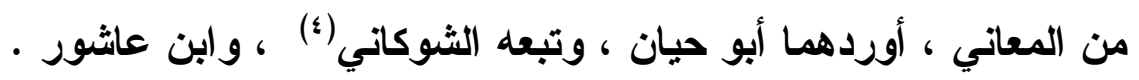

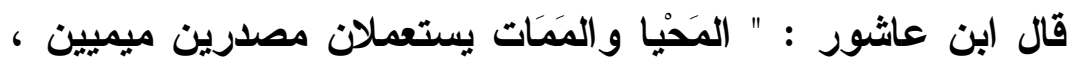

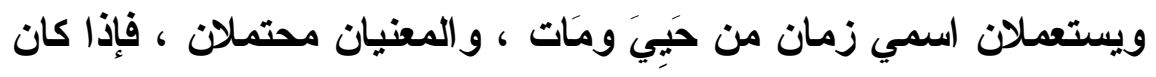
المراد من المحيا والممات المعنى المصدري كان على حذف مضاف

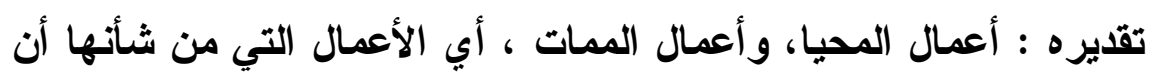

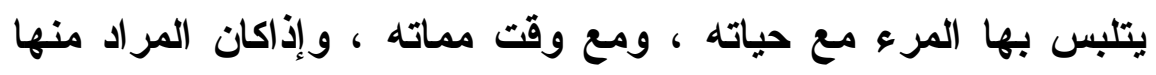

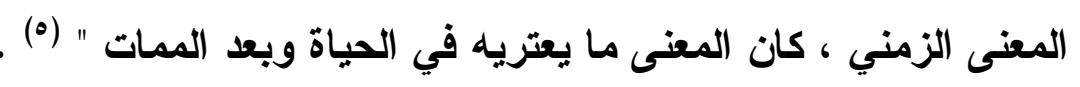

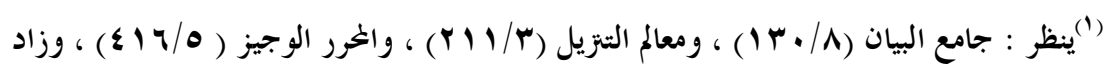

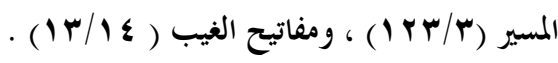

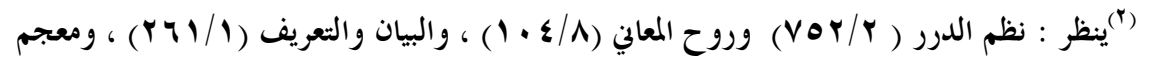

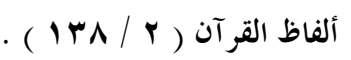

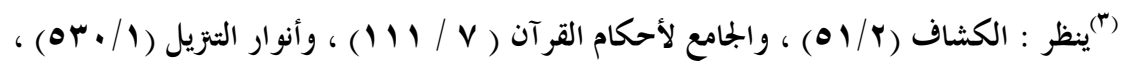

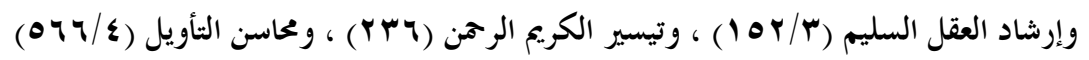

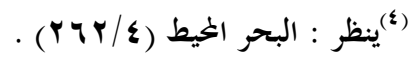

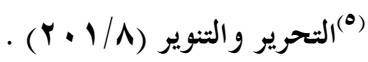


ويبدو لي مما سبق أنَّ الراجح هو المصدر الميمي ، أي : الحياة

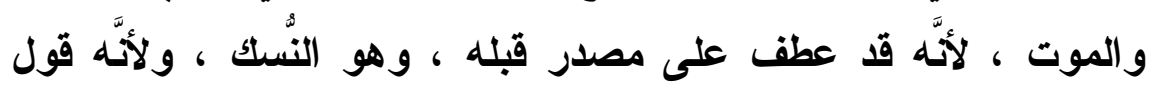

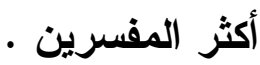

\section{مَعَاش}

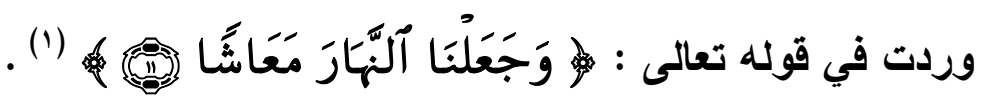

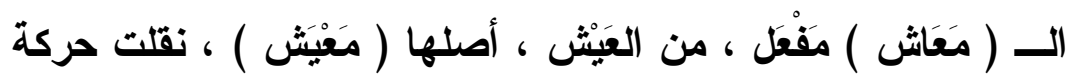

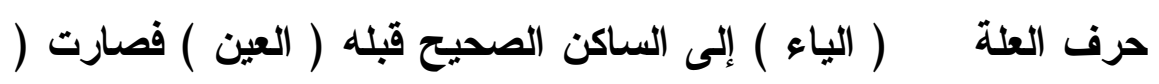

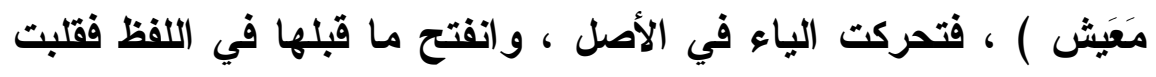

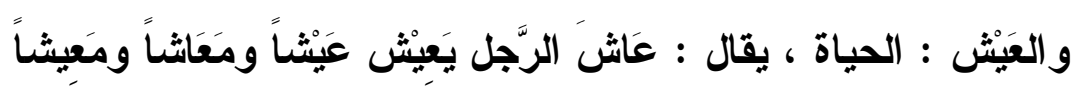

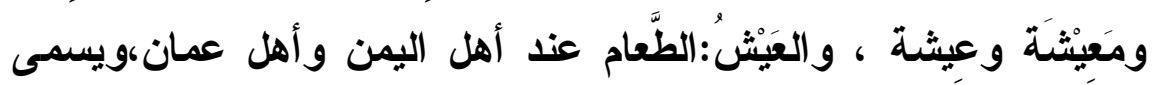

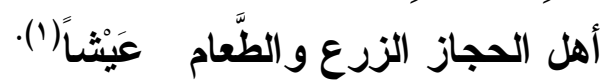

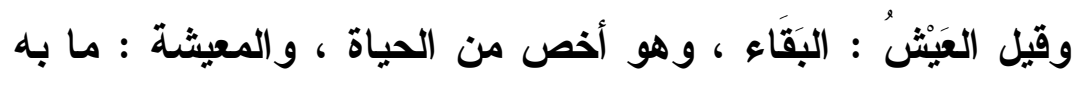

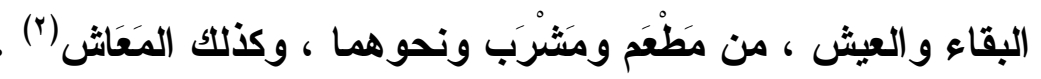

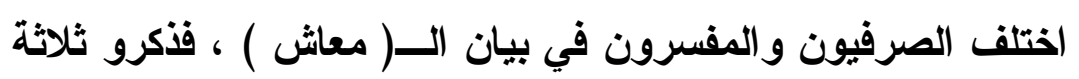
آراء في معناها :

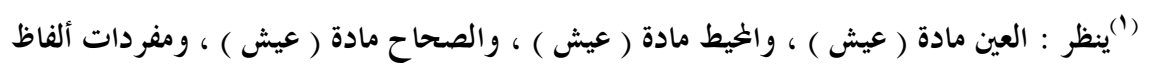

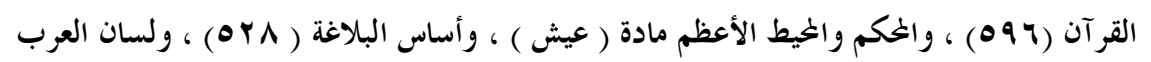

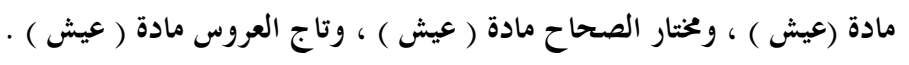

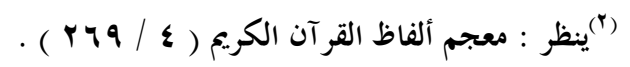


الأول : أنَّ المَعَسـاش مصدر ميمي ، بمعنى : العيش ، عند الصرفيين ويعض المفسرين .

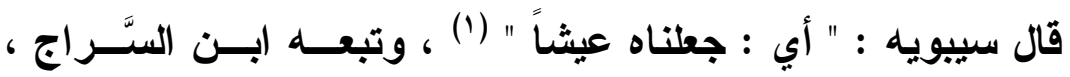

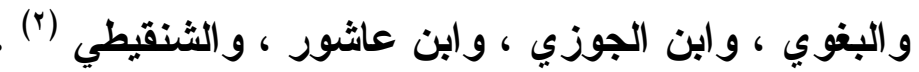

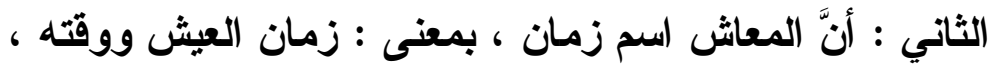
تستيقظون فيه ، وتنقلبون في حوائجكم ومكاسبكم وهذا ما ذهب إليه الزمخثري ، و النســفي ، وأبـو حيــان ، قــال الزمخشري : " أي : وقت معاش تستيقظون فيه وتنقلبون في حسو أئجكم

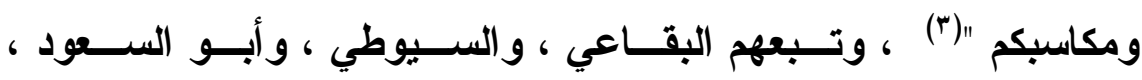
و الثوكاني (؛).

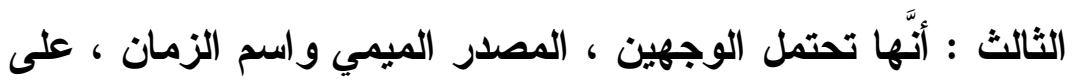

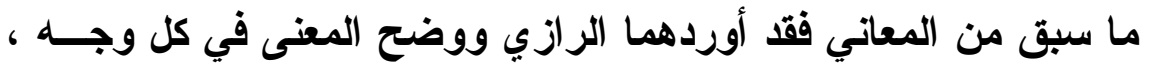

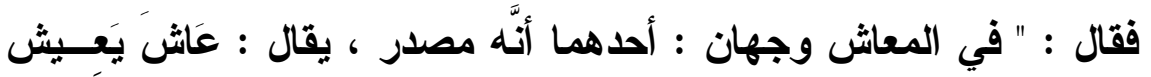

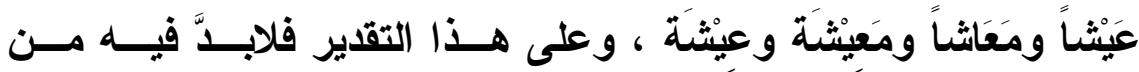

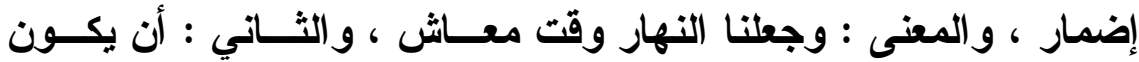

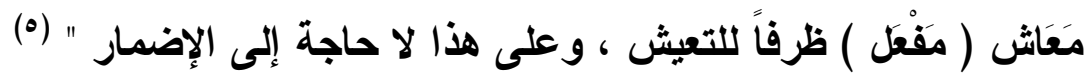

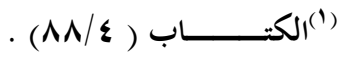

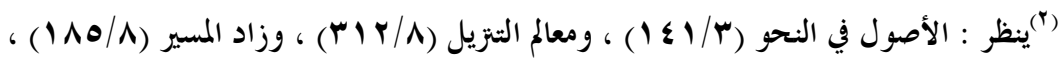

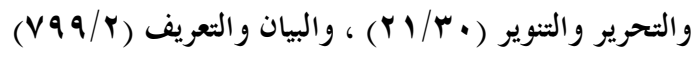

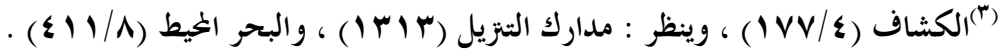

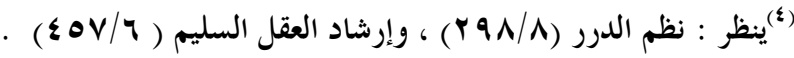

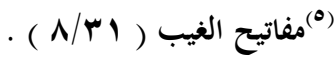




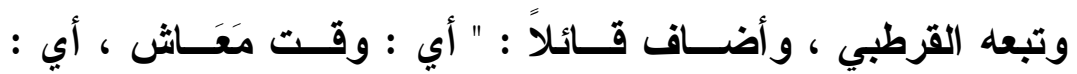

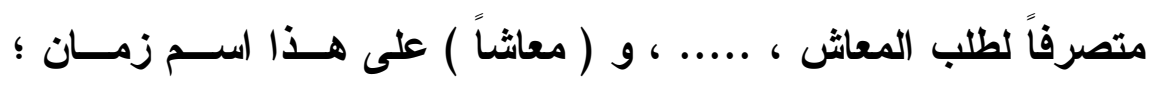

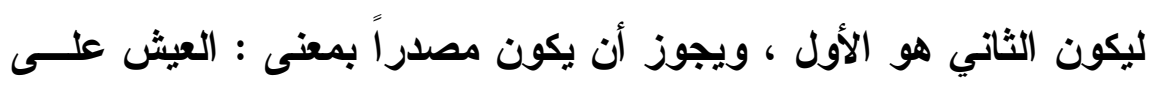

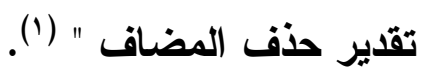

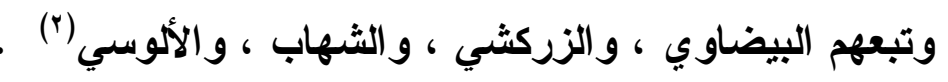

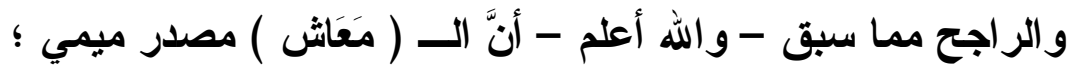
لأنَّهَ

1ـ أكثر المفسرين عليه ، وهو رأي الصرفيين أيضاً .

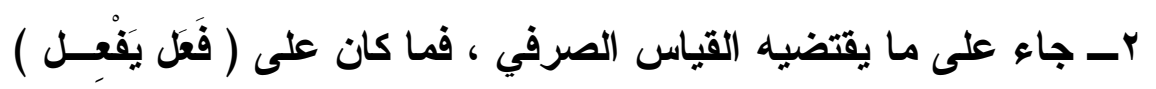

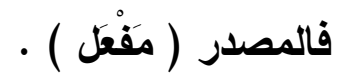

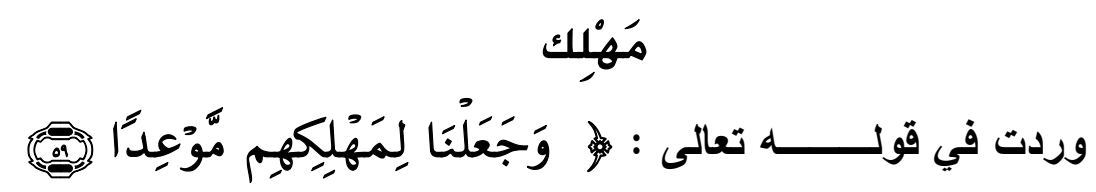
(r)

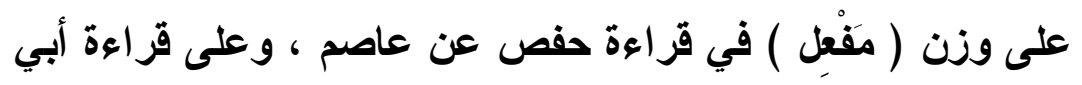

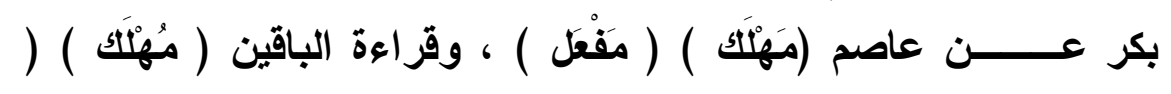
مُفْكَ () م

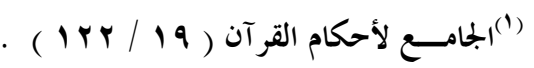

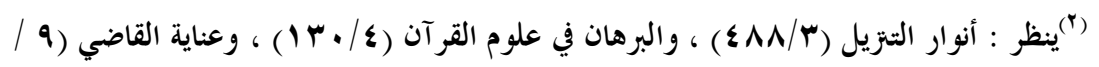

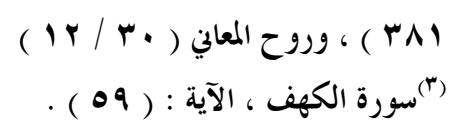


قال ابن مجاهد : " قرأ عاصم وحده في رواية أبي بكر ( لمَهْكَكهم )

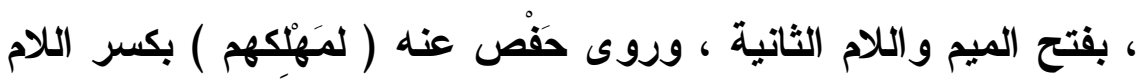

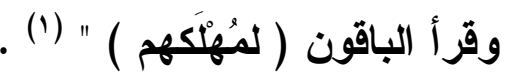

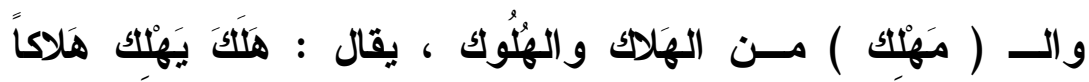

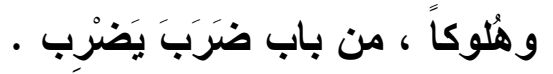

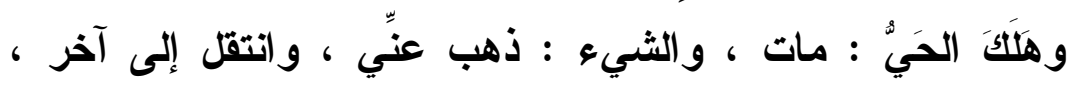

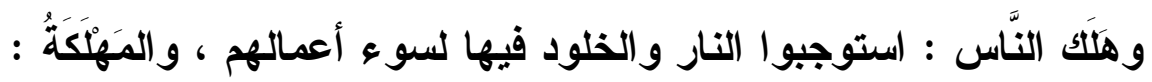

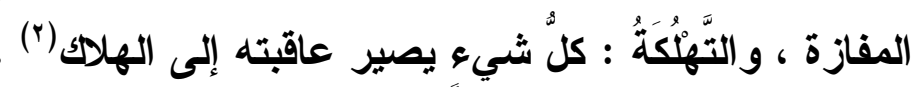

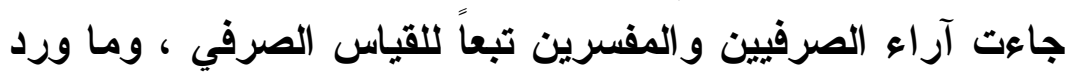

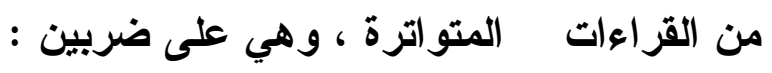

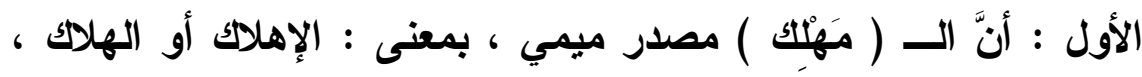

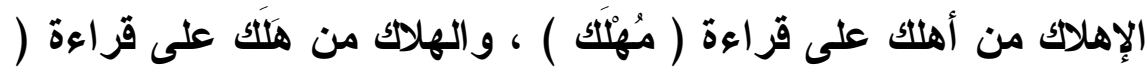

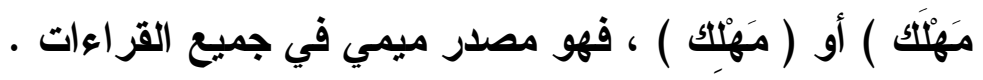
ذهب إلى ذلك الطبري بقوله : " قرَ أ عامة قُرَّاء الحجاز

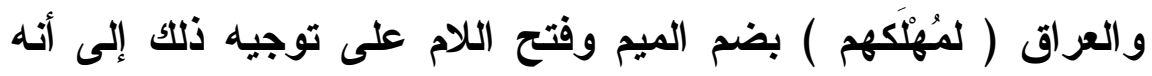

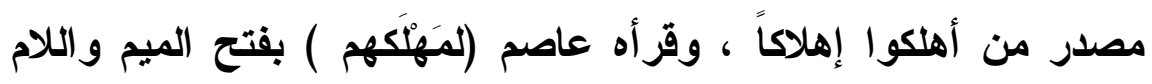

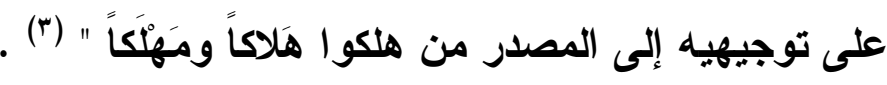

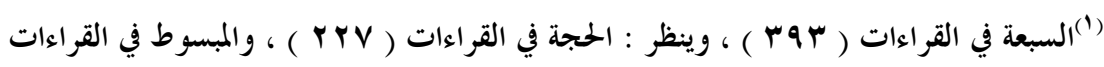

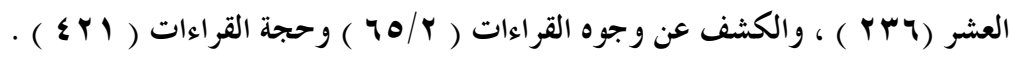

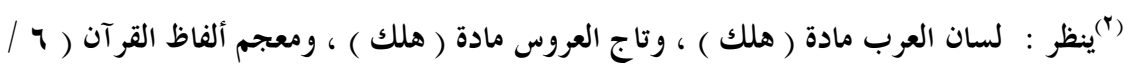

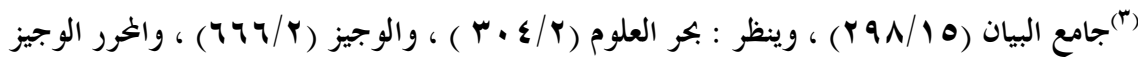

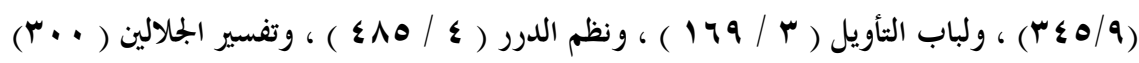

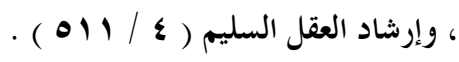


وحمل البيضاوي قراعة ( مَهْتلك ) على الثَاذ من مصادر ( يَفْعِ ) ،

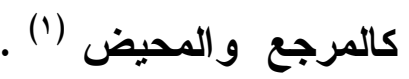

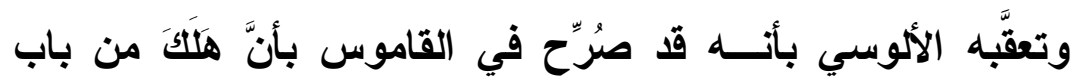

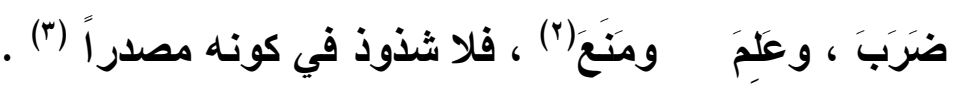

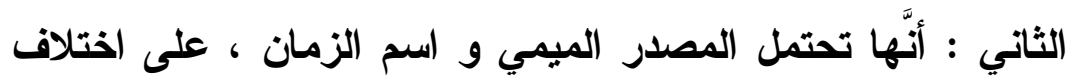

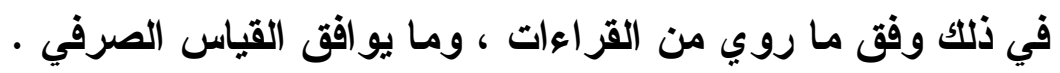

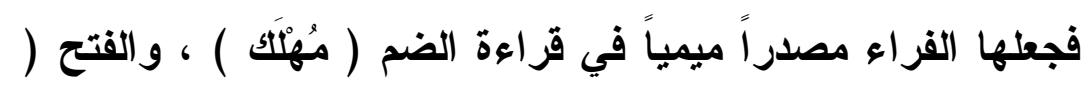

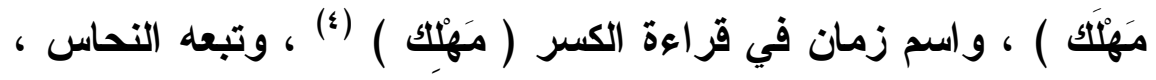

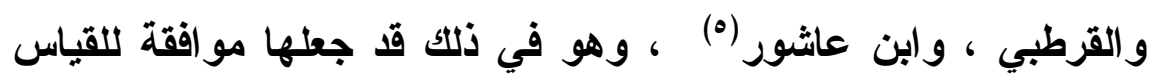

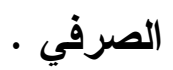

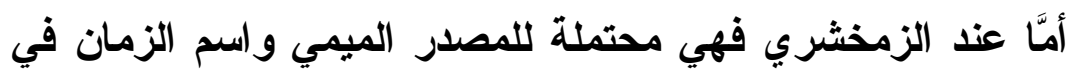

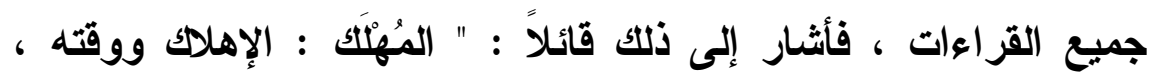

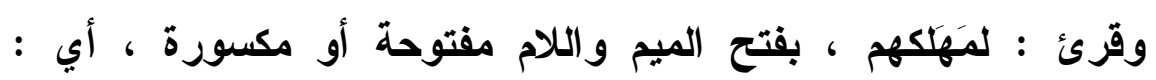

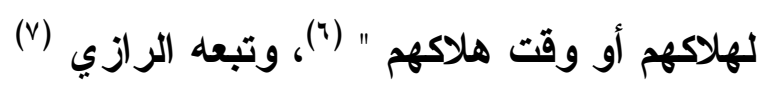

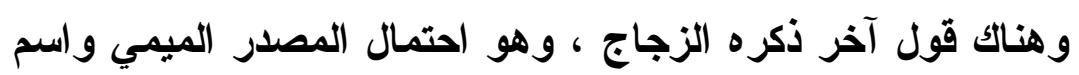

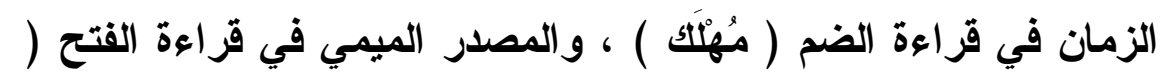

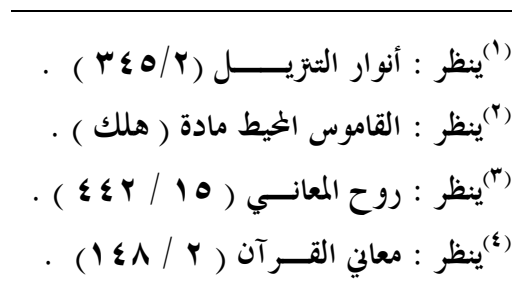

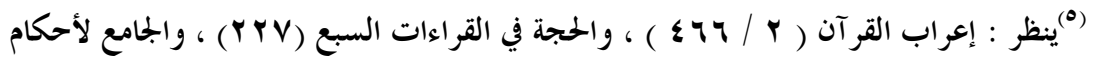

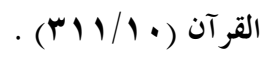

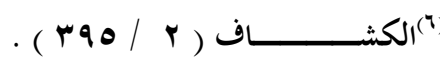

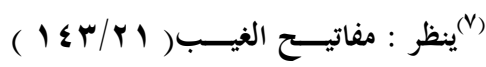

$$
\begin{aligned}
& \text { - } r \cdot r \cdot-\text { - }
\end{aligned}
$$




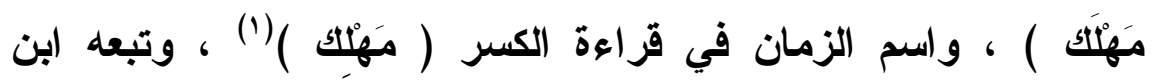

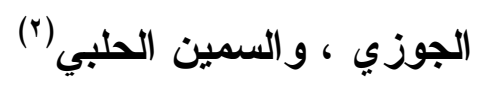

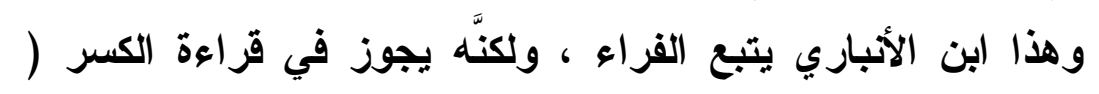

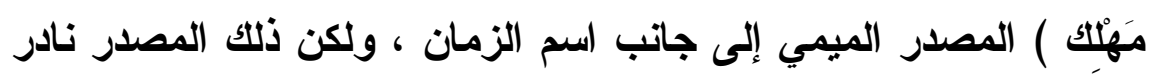

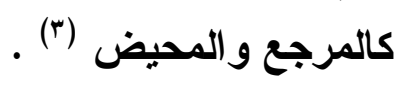
أمَّا البغوي و النسفي وأبو حيان فقد انفرد كلّ منهم بقول لم يذكره

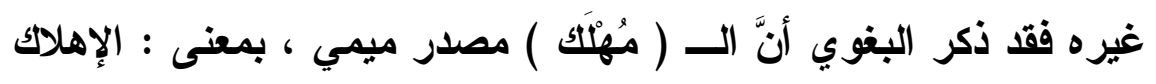

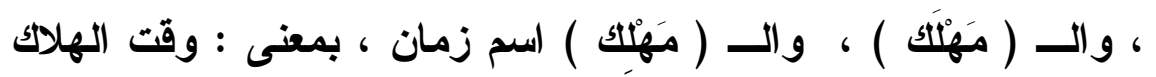

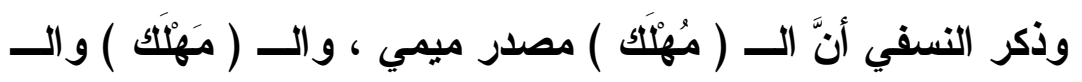

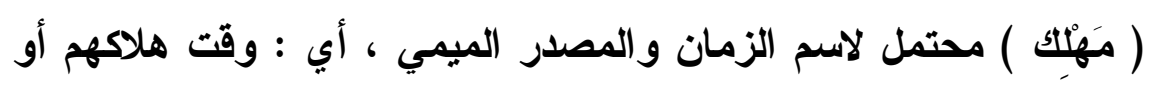

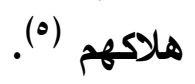

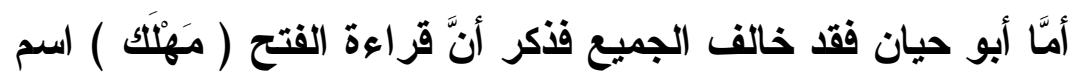

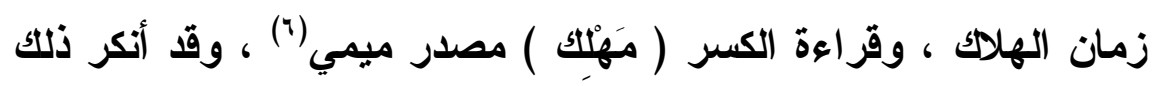

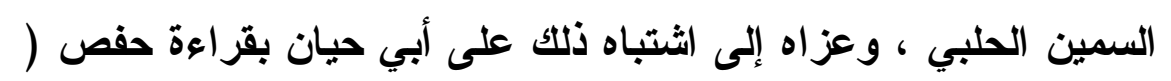

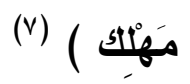

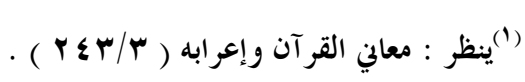

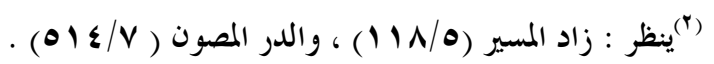

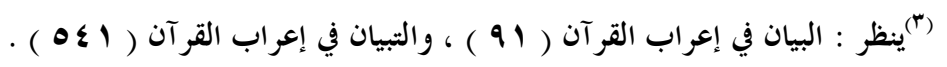

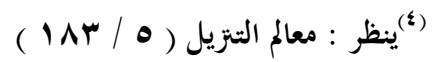

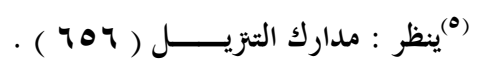

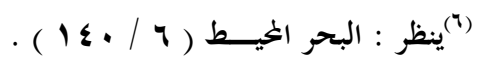

$$
\begin{aligned}
& \text { (v) } \\
& -Y^{-} \cdot Y_{1}-
\end{aligned}
$$


ويبدو أنَّ الراجح مما سبق هو المصدر الميمي ، بمعنى : الإهلاك

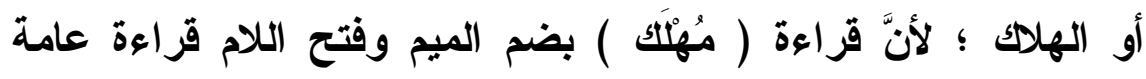

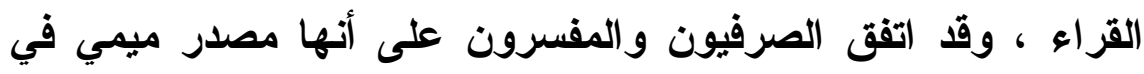

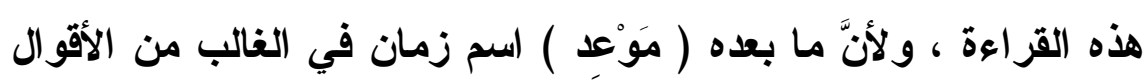

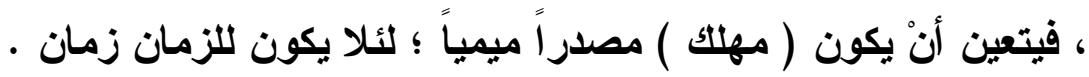

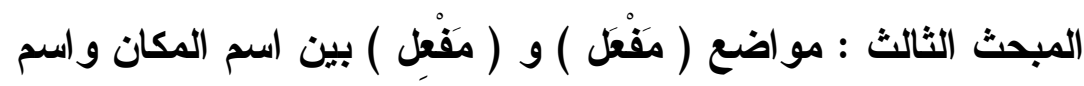
الزمان

\section{مَحِلِّ}

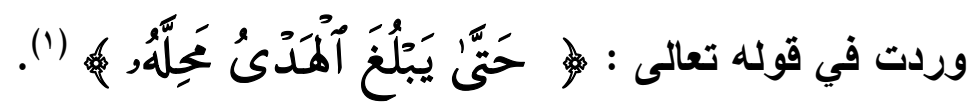

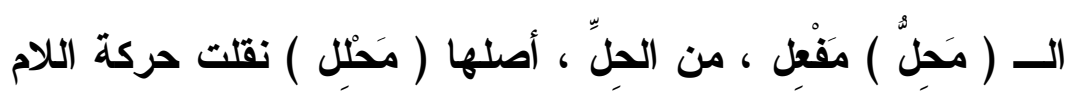

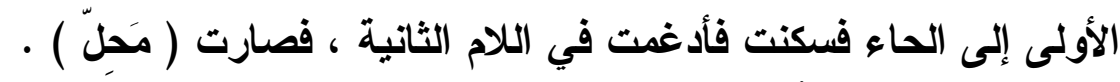

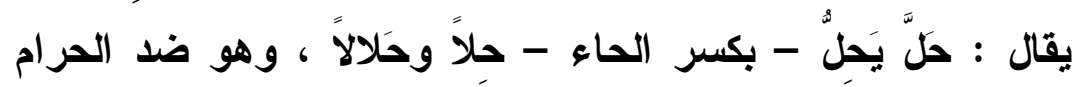

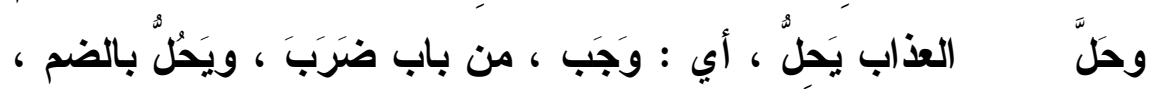

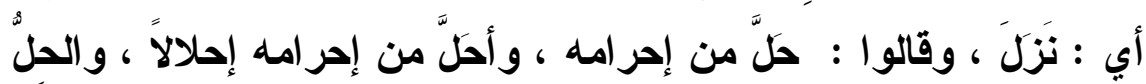

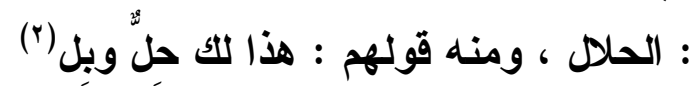

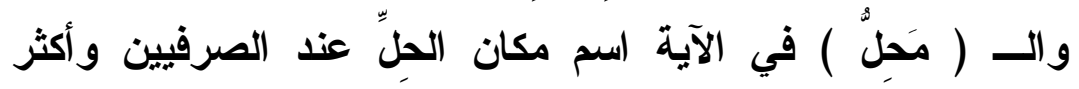

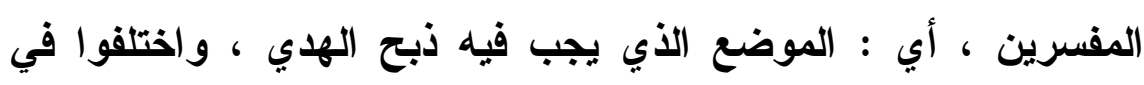
تعيينه ، فقال مالك و الثافعي وأحمد : الموضع الذي أحصر به به ؛ إقتاءًا

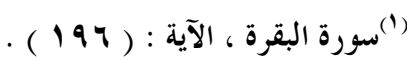

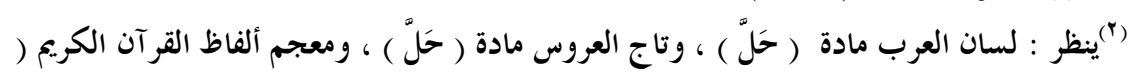
( IIN/T 
برسول الله صلى الله عليه وسلم حيث أحصر في الحديبية ، وقال أبو حنيفة : الحرم .

ذهب إلى ذلك الطبري ، و الجصاص ، و الواحدي ، والبغوي ،

و الزمخشري ، و ابن عطية ، وابن الجوزي ، وتبعهم أكثر المفسرين .

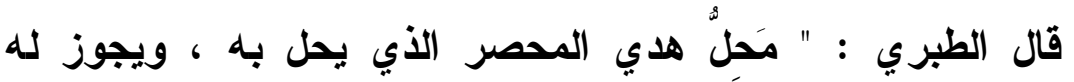

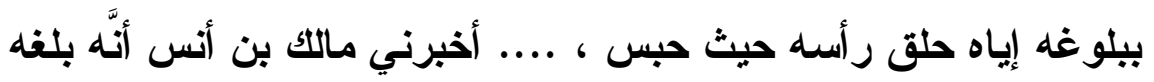

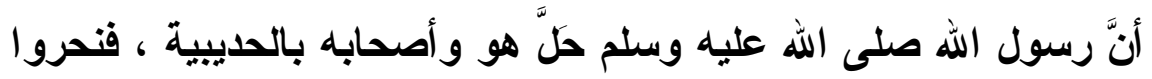

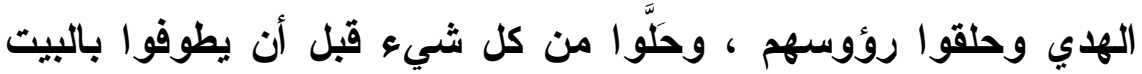

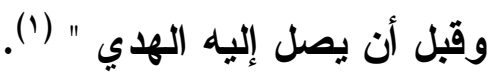

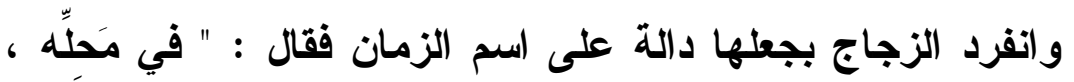

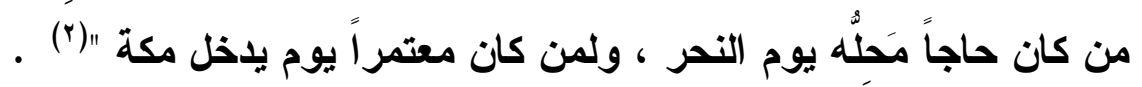
وقد أورد العكبري احتمال اسم المكان واسم الزمان ؛ لأنَّ القياس

الصرفي يجيز ذللك ، مع ترجيحه لاسم المكان .

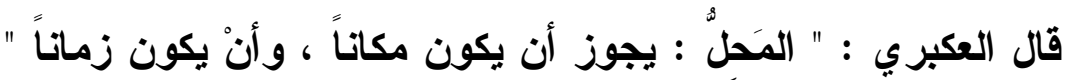

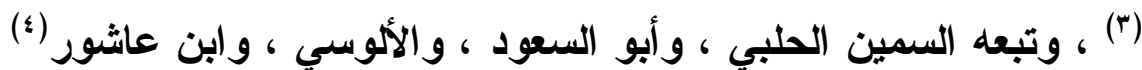

(1)

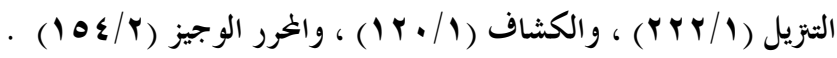
(T) (")

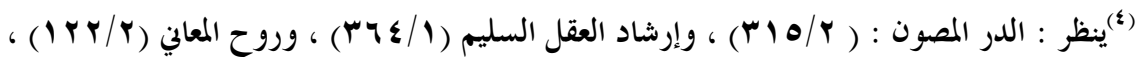

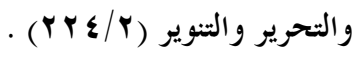


ويبدو لي أنَّ الــ ( محَلَّ ) في هذه الآية اسم مكان الحٍِّ ، وهو

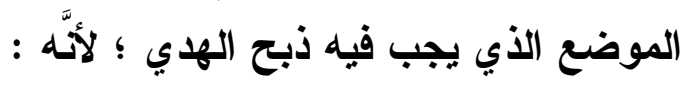
اـ قول أكثر المفسرين والصرفيين واختيارهم .

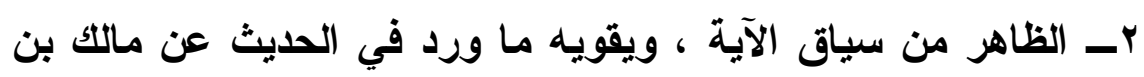

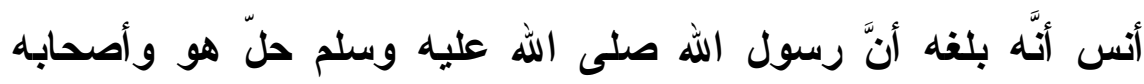

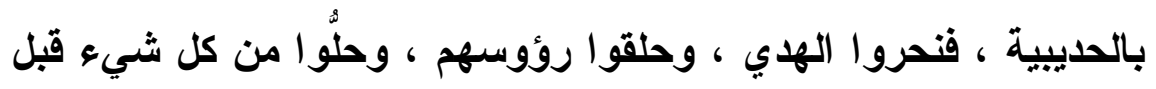

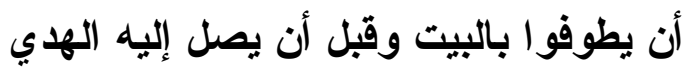

\section{مَعْزْل}

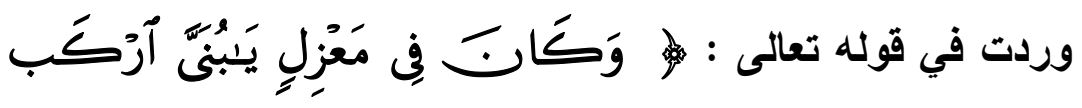

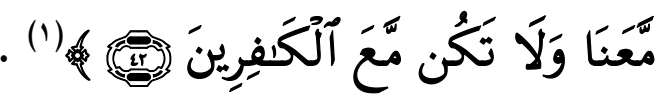

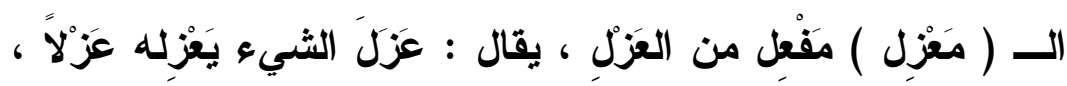

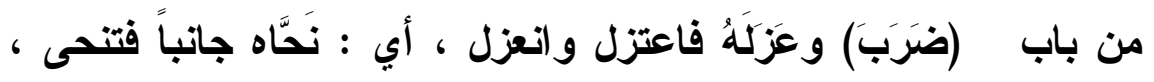

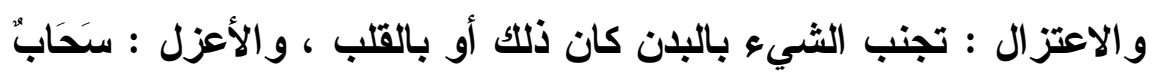

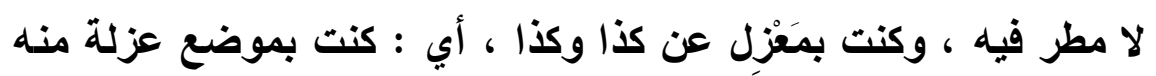

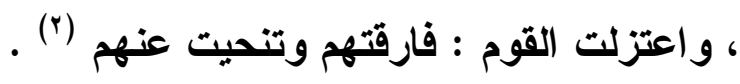

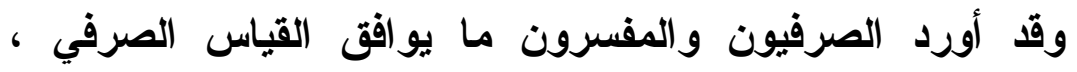

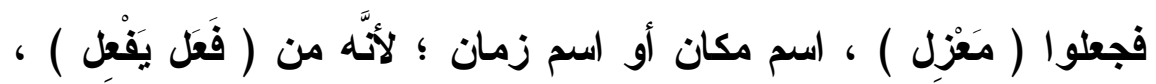

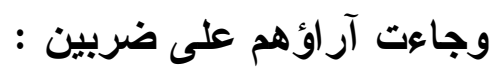

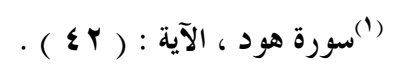

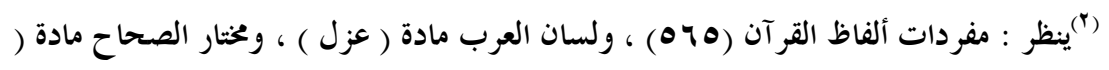

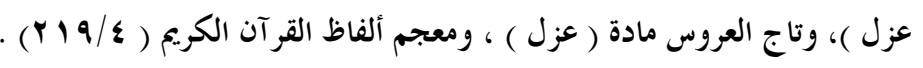


الأول : أنَّ الـــ ( مَعْزِل ) اسم مكان العُزْْلة و الانفراد إمَّا حقيقة أو

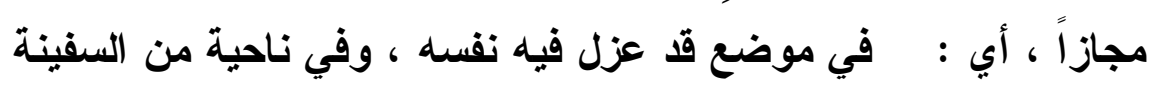

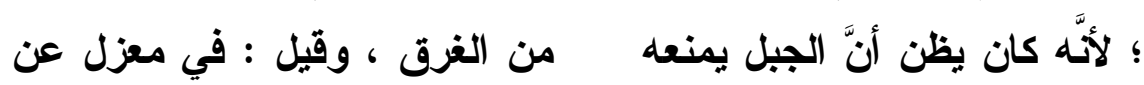

دين أبيه .

ذهب إلى ذلك الصرفيون وأكثر المفسرين .

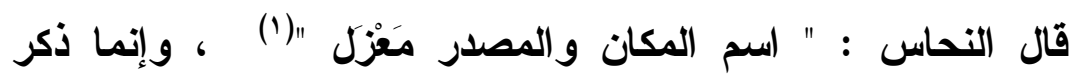

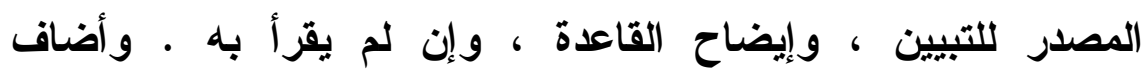

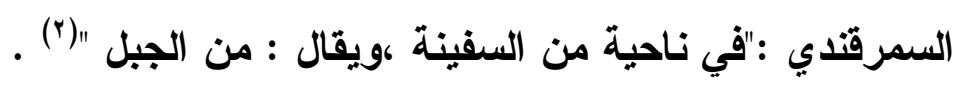

وأورد مكي ما يوهم قراءة الفتح ، فقال :"منْ كسر الزاي جعله

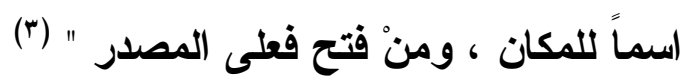

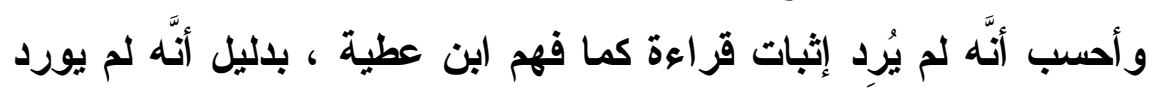

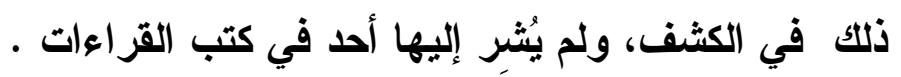

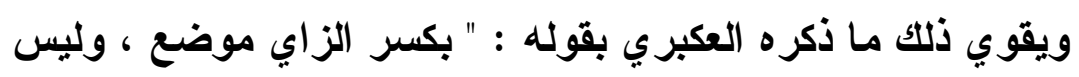

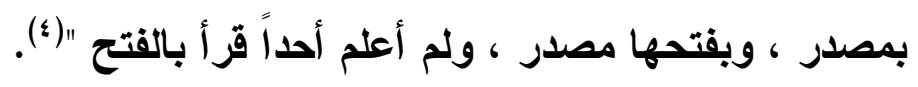

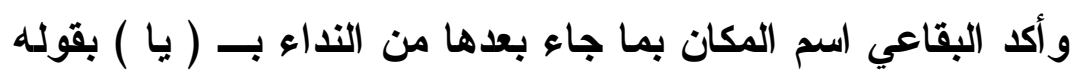

تعالى " يا بني اركب " فقيه بعض البعد البعد في المكان(ه) . (1)

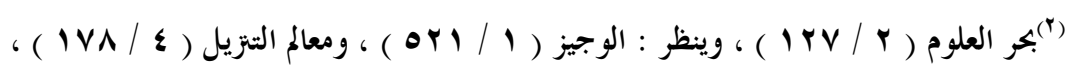

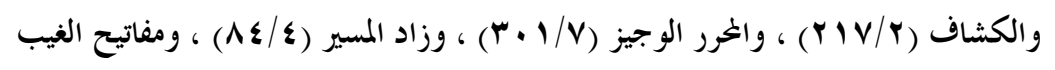

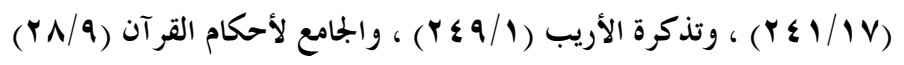

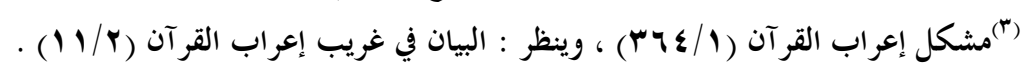

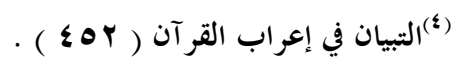

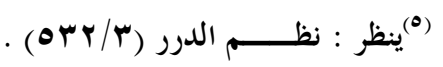


الثاني : أنَّ الـــ ( مَغْزِل ) اسم مكان العزلة مع تجويز اسم الزمان

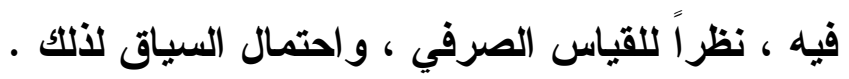

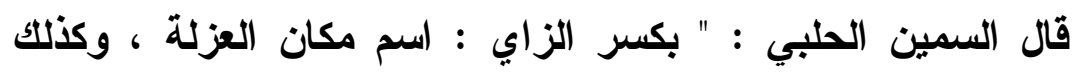

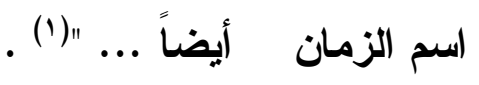
وقتَّل الثهاب الزمان أشمال اسم الزمان فقال : " المَزْزل بالكسر اسم مكان

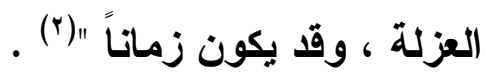

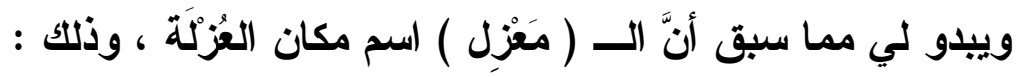

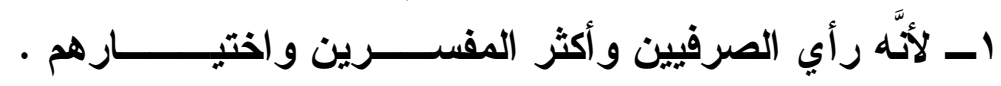

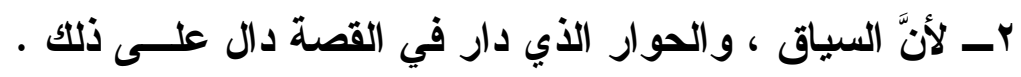

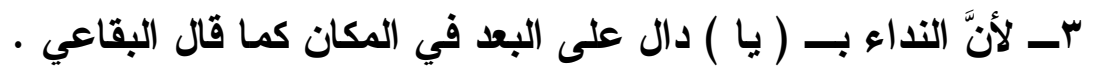

\section{مَعَماد}

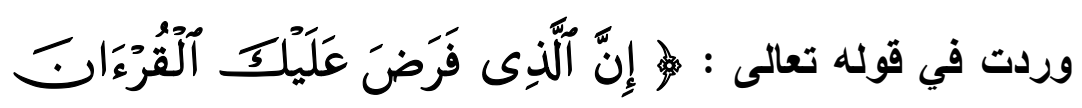

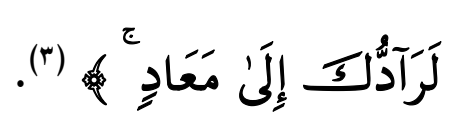

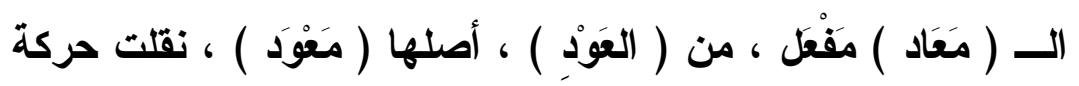

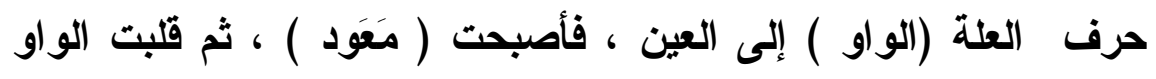

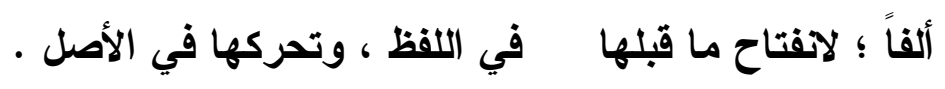

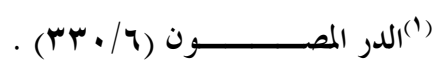

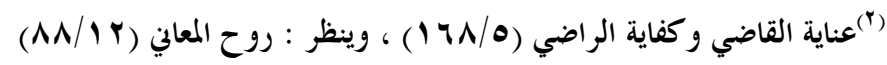

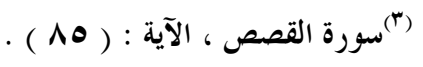




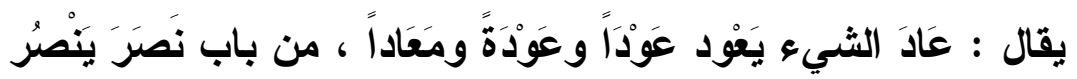

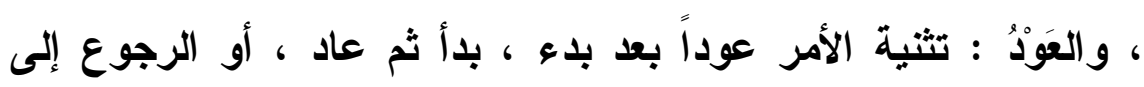

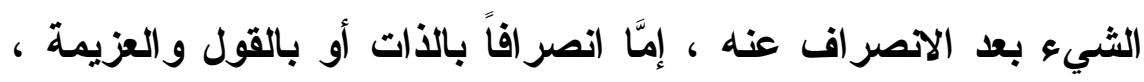

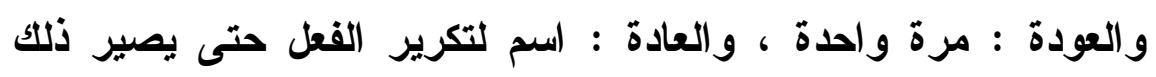

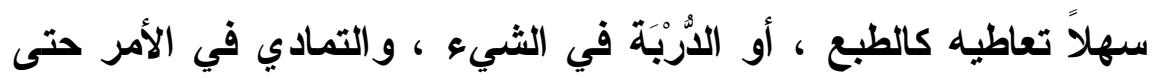

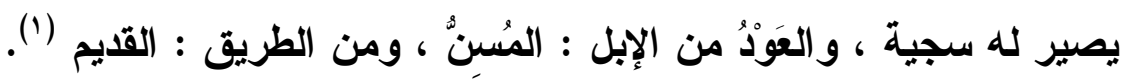

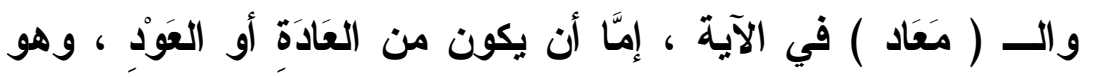

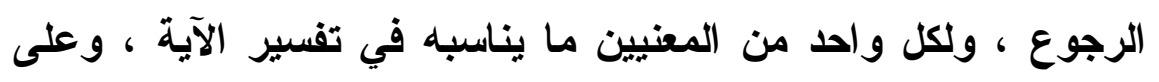

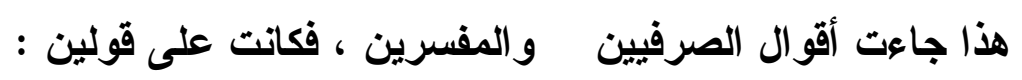

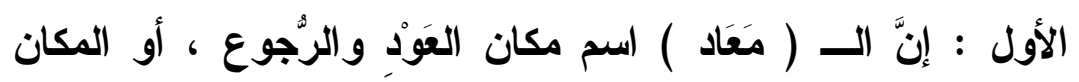

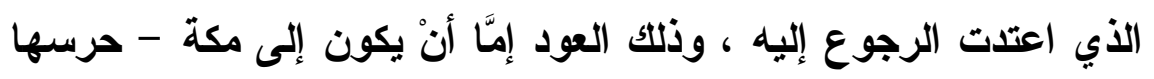

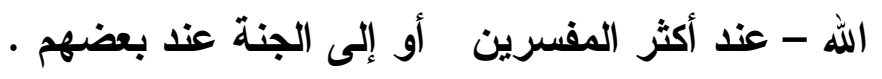
وإن كان المعنى العود إلى الجنة فتوجيهه أنَّ النبي صلى الله على عليه وسلم كان في ظهر آدم عليه السلام إذ كان فيها ، وهناك توجيه آخر ، وهو أنَّه صلى الله

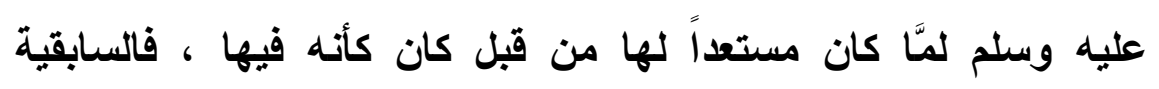

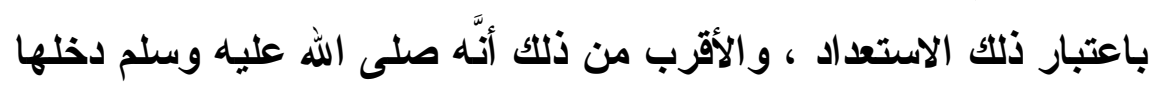

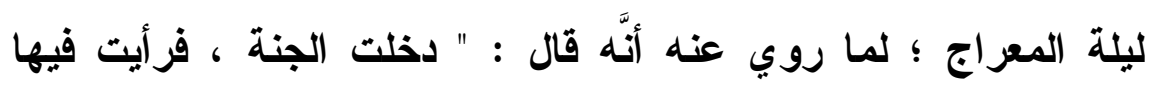

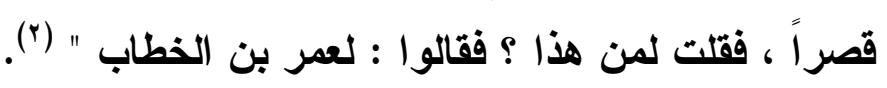

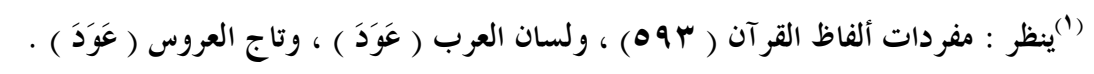

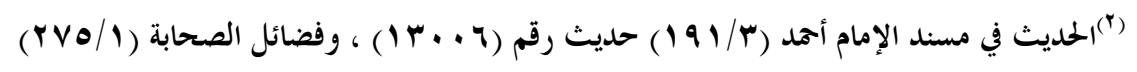

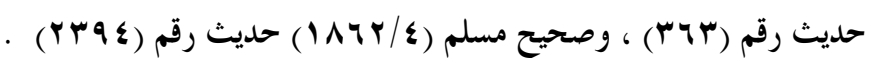


ذهب إلى ذلك الفراء ،و السجستاني ،و الزجاج و السمرقندي ،وتبعهم

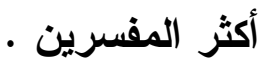

قال الفراء : " يعني إلى مكة ، والمعاد ههنا إنما أراد به حيث

ولدت " (1)

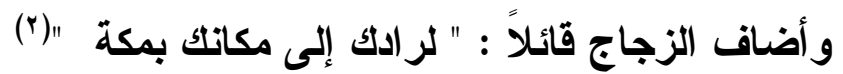

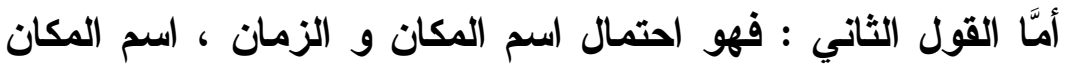

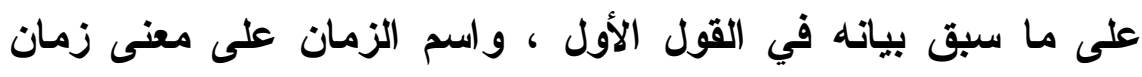

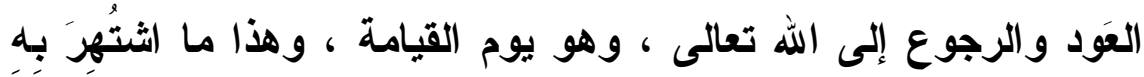

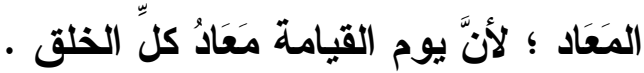

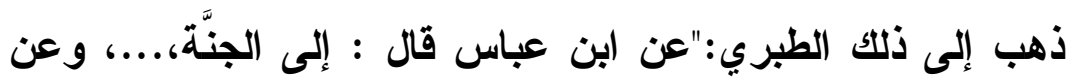
عكرمة والحسن ، قال : يوم القيامة ، وقال آخرون : لرادك إلى إلى الجين

الموضع الذي خرجت منه ، وهو مكة "(") . وذكر هذه الأقو ال النحاس ،و السمعاني ،والكرماني ،و البغوي ،و ابن ولن

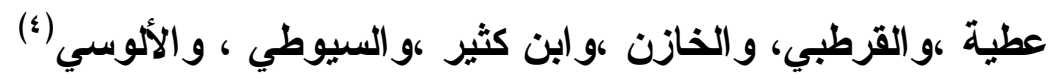

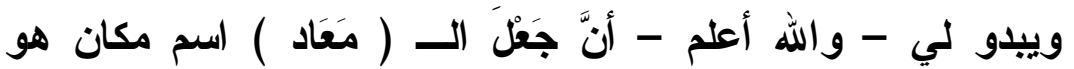

الأولى ، ويراد به مكة المكرمة ، ويقوي ذلك :

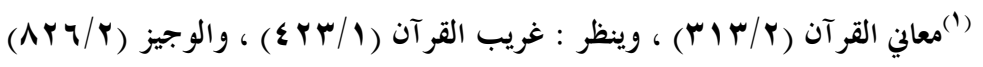

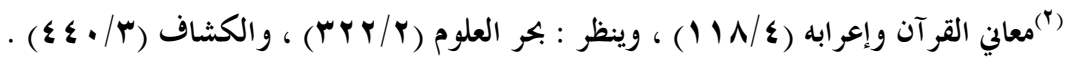

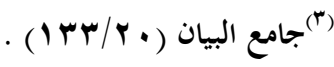

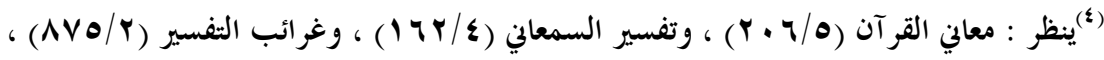

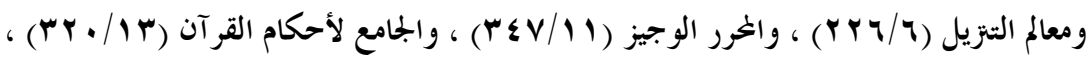

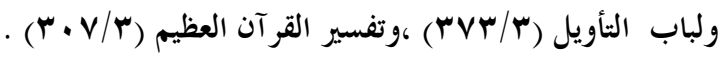


ا- ما ورد في سبب نزول الآية ، أخرج ابن أبي حاتم عن الضحاك قال

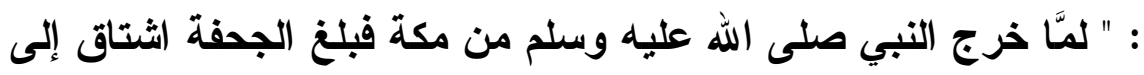

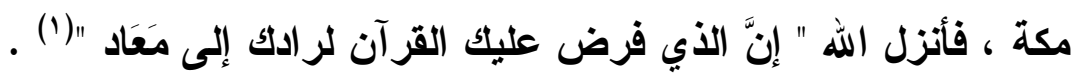

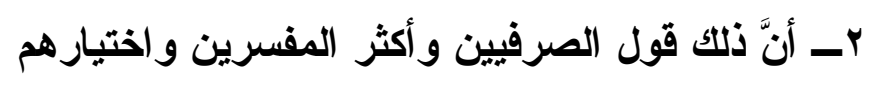

\begin{abstract}
مَوْعد

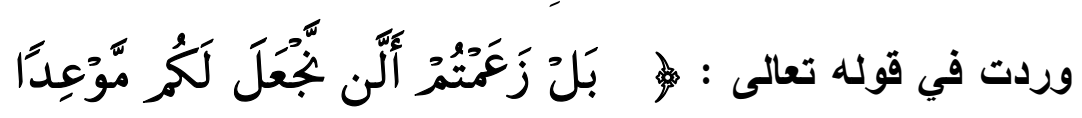

()

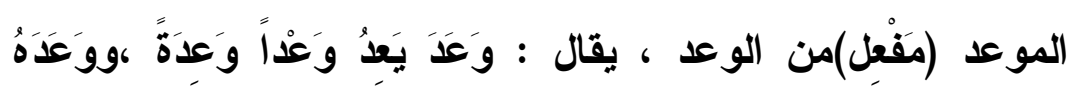

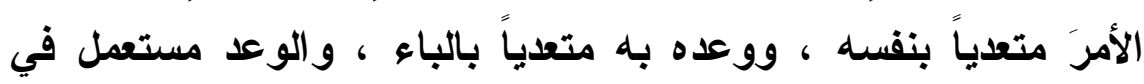

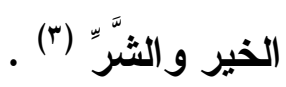

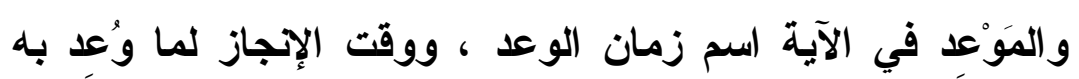

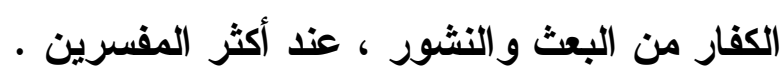

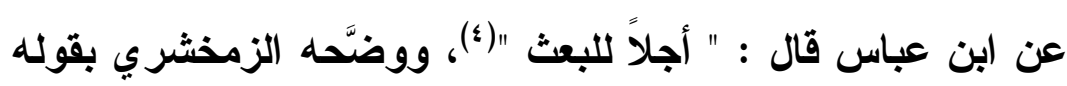

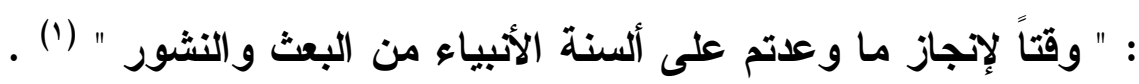

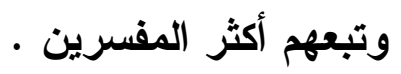

(1)

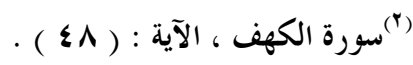

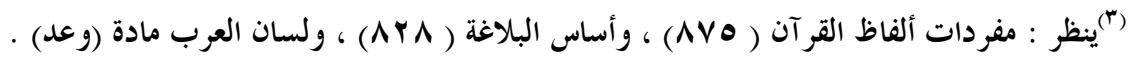

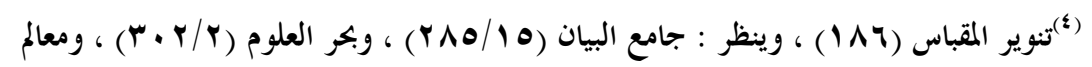

التزيل (1) 
وجوزّ بعض المفسرين احتمال اسم المكان واسم الزمان ، ويكون المعنى : مكان وعد للمحاسبة ، أو زمان وعد لإنجاز ما وعدتم من

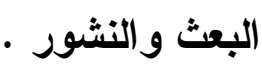

قال النسفي : " وقتاً لإنجاز ما وعدتم على ألسنة الأنبياء من البعث والنشور أو مكان وعد للمحاسبة "( (ז). ويبدو لي مما سبق - والله أعلم - أنَّ الـــ ( مَوْعِد ) في الآيـة اسم زمان الوعد ؛ ا - لأنَّ الخطاب لمنكري البعث والقيامة ، فهو تقرير لما أنكروه في

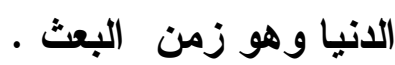
r - لأكَّه قول أكثر زمن المفسرين و اختيارهم

المبحث الرابع : مواضع ( مَفْعَل ) و ( مَفْعِل ) المشتركة بين المصدر الميمي واسم المكان واسم الزمان

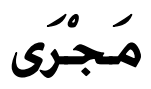

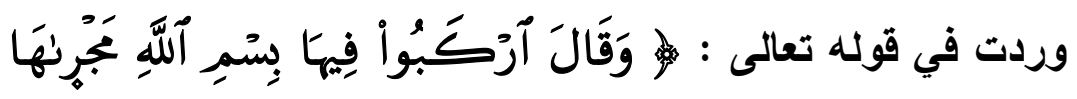

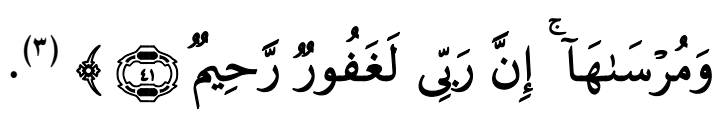

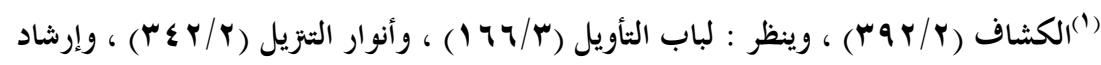

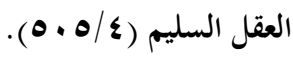

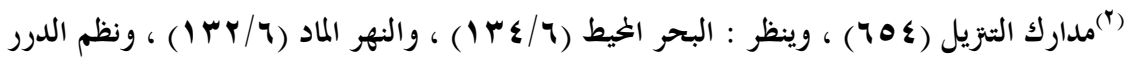
$(\varepsilon \vee \varepsilon / \varepsilon)$

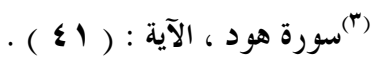


الــ (مَجْرَى) مَفْعَ ، أصلها ( مَجْرَي ) ،تحركت الياء و انفتح ما

$$
\text { قبلها فقلبت ألفاً . }
$$

وهي من الجَرْي أو الجَرَيَان ، وهو : المَرُ السريع ، يقال : جرى

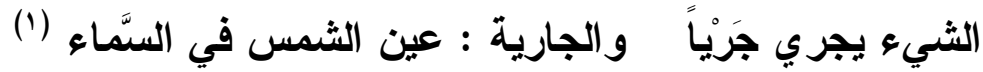
واختلف القراء في قراعتها ، فقرأها ابن كثير ونافع و أبو عمرو و وابن عامر وعاصم في رواية أبي بكر بضم الميم ( مُجْرَاها ) ، وقرأ حمزة و الكسائي وحفص عن عاصم بفتح الميم وكسر الراء ( مَجْرِاها )

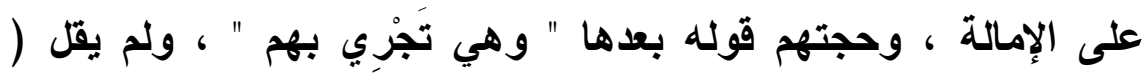

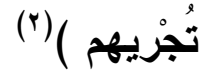
وبناء على ما ثبت من القراءات السبعية بضم الميم وفتحها ، جاءت آراء الصرفيين والمفسرين على النحو الآتي :

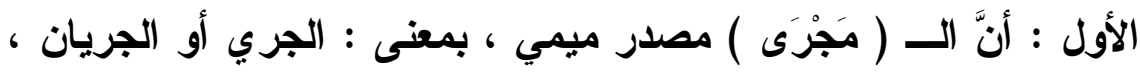

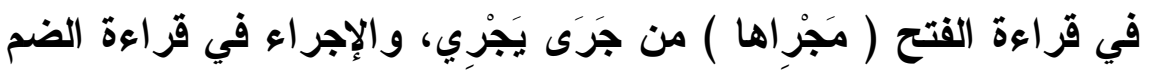

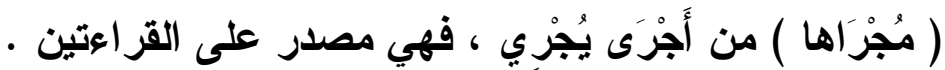
ذهب إلى هذا الرأي البغوي ، والرازي ، والعز ، والخازن ، وابن

كثير ، والثعالبي ، و الجلالان (־).

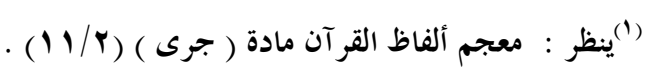

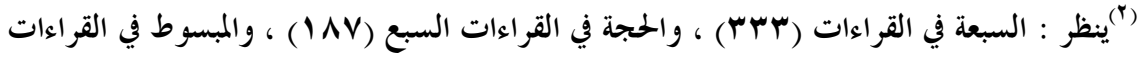

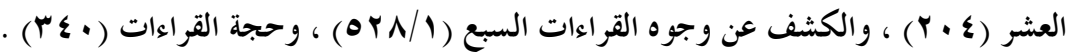

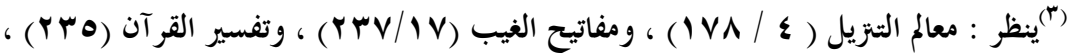

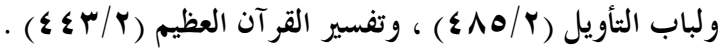




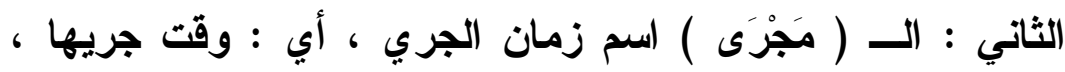

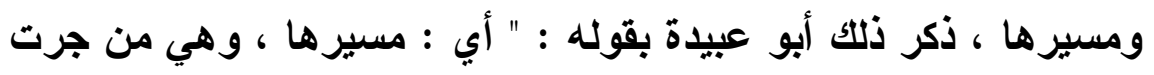

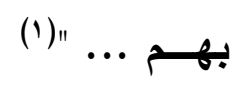

وتبعه الكرماني ، وأضــاف : " ظرف زمان ، أي : وقت جريها "(؟)

الثالث : أنَّها تحتمل المصدر الميمي واسم الزمان ، أي : جريها ، جريها

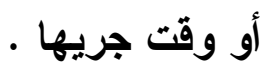

أورد هذين الاحتمالين الفراء ، والزجاج ، وابن الأباري ، وابن

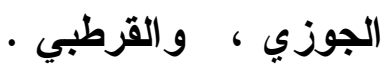

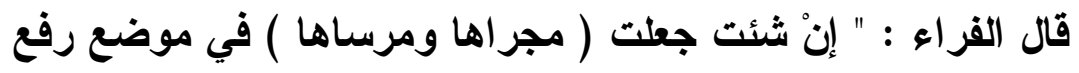

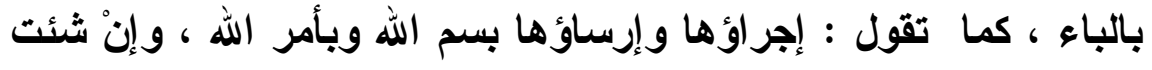

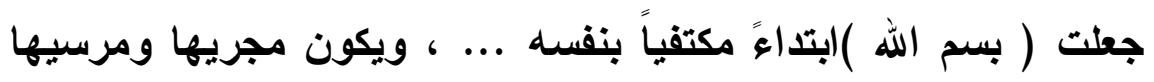

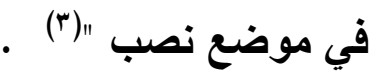
الرابع : أن تكون مصدراً ميمياً مع جواز اسم المكان ، و انفرد بذلك الكو

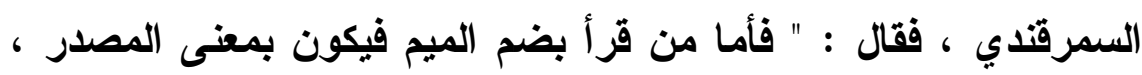

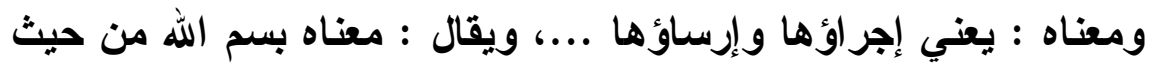

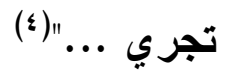

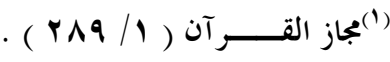

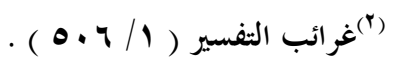

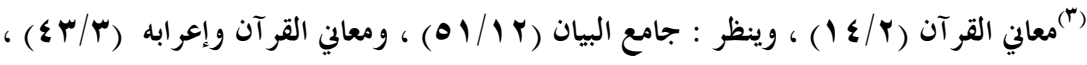

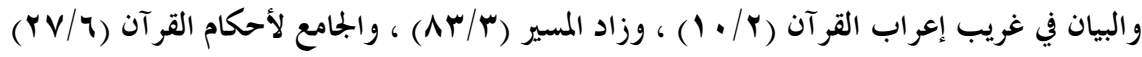

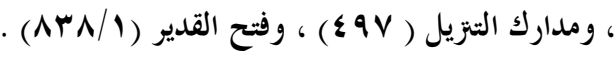

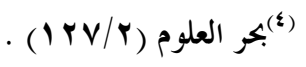


الخامس : أنَّها تحتمل المصدر الميمي ، و اسم الزمان ، و اسم

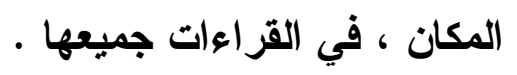

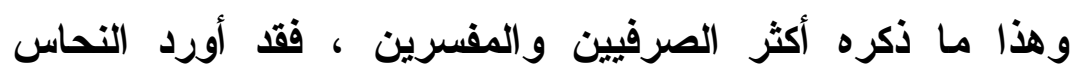

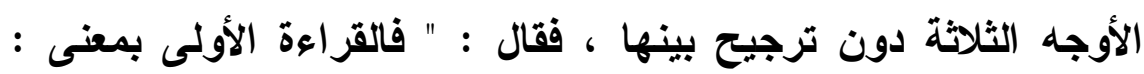

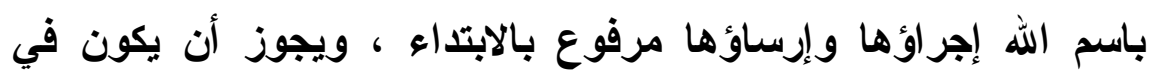

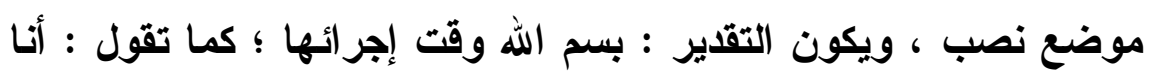

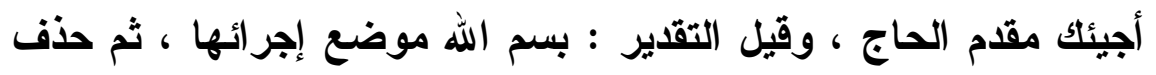
موضع و أقيم مجر اها مقامه "( (1) . ل

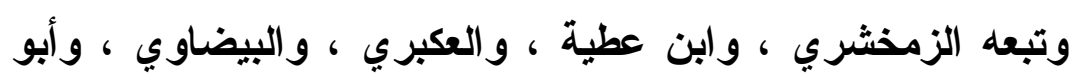

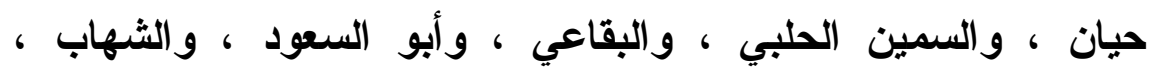

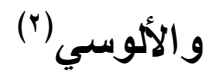

ويبدو لي مما سبق أنَّ الــ ( مَجْرى ) مصدر ميمي ، بمعنى الهُ

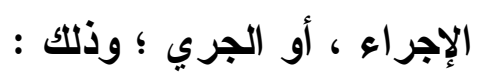

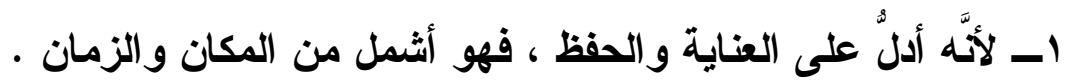

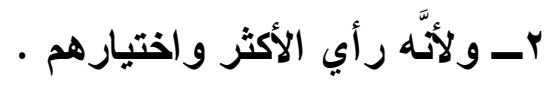




\section{مَطْلَع}

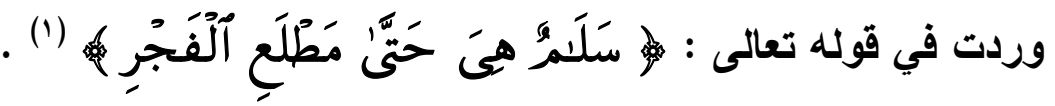

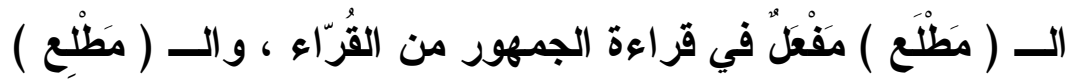

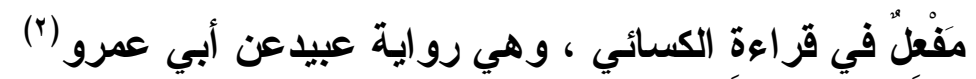

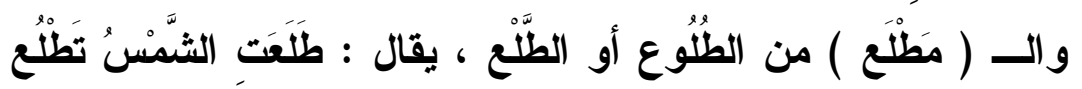

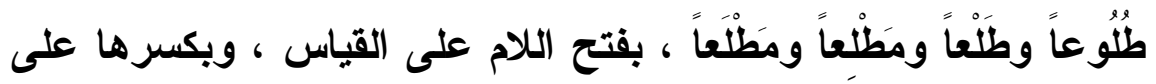

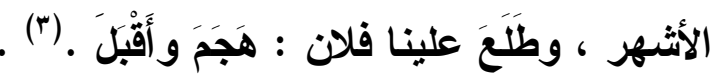

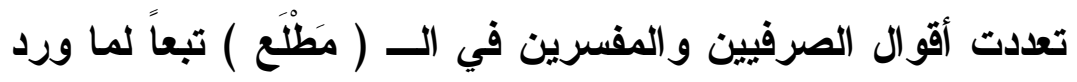

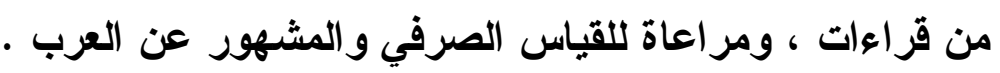

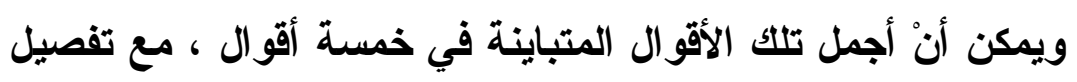

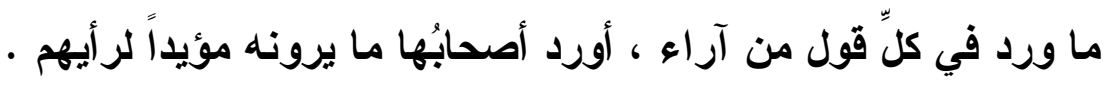

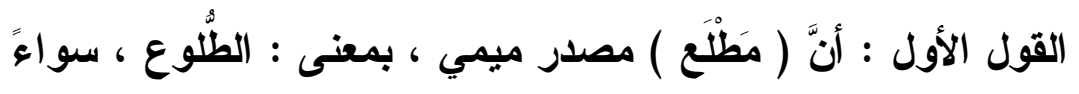

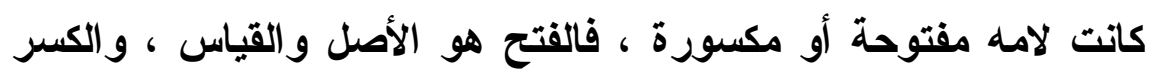

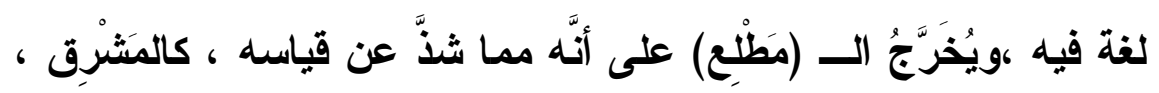

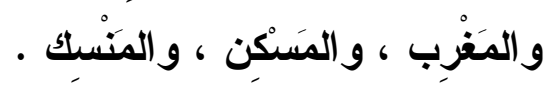

ذهب إلى هذا القول أكثر الصرفيين والمفسرين ، ولفئ ، ولنرى الأخفش

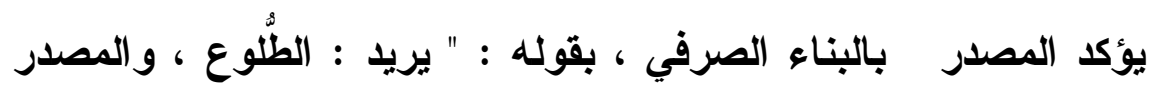

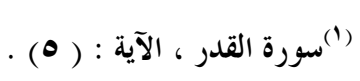

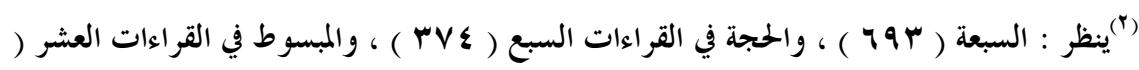

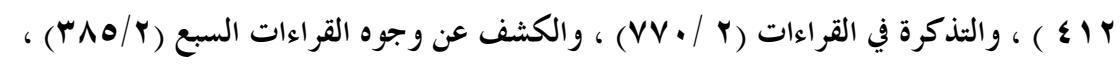

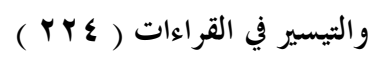
("اينظر : اللسان العرب (طلع) ، والقاموس الخيط( طلع ) ، وتاج العروس مادة ( طلع ) . 
ههنا لا يبنى إلا على ( مَفعل )"(1) وتبعه الواحدي ، والعز ، والخازن ، و النسفي . (؟).

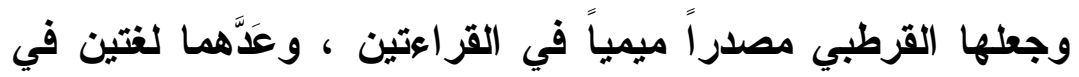

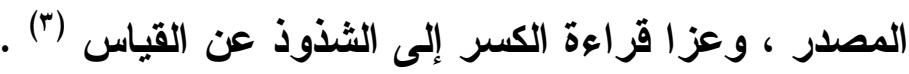

القول الثاني : تجويز المصدر الميمي ، واسم المكان ، مع اختلاف

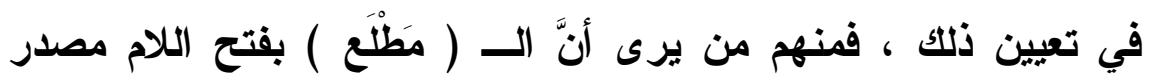

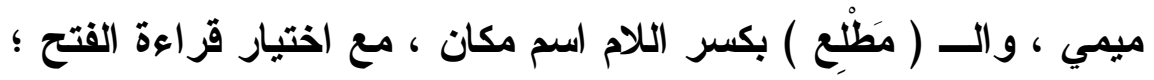

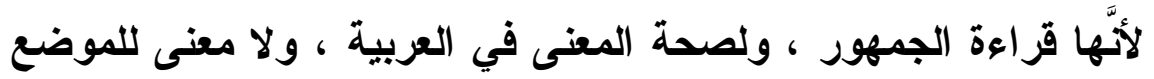

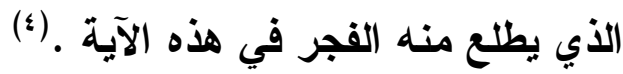

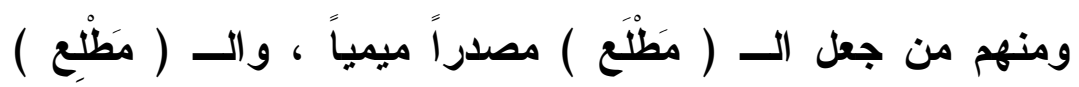

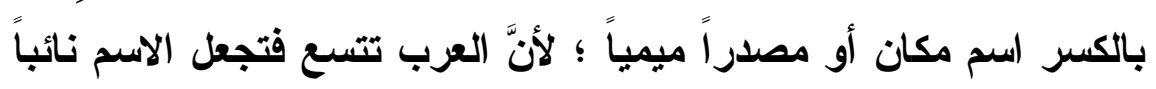

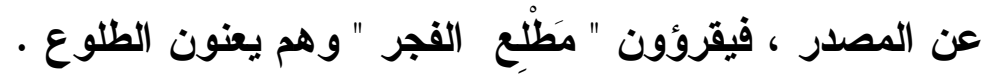

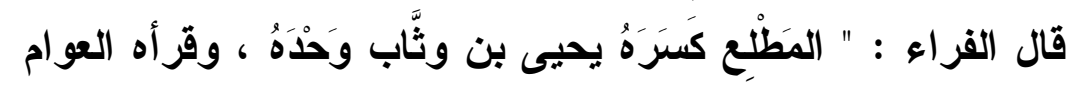

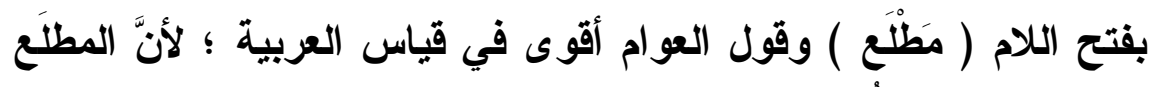

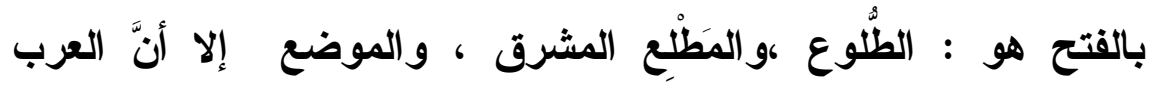
يقولون ...مَظْعَاً فيكسرون وهم يريدون المصدر " (0).

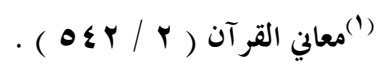
(Y)

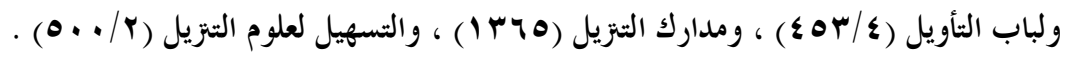

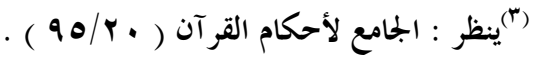

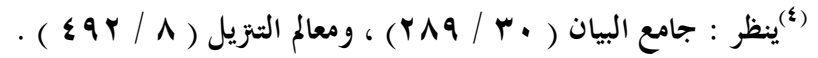

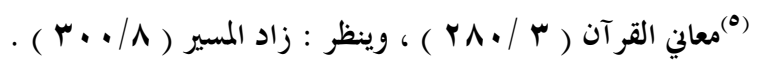


ومن المفسرين من خرَّج القراعتين على لغات قبائل العرب ، فالفتح و الكسر للمصدر عند بني تميم ، والفتح للمصدر ، والكسر للككان عند

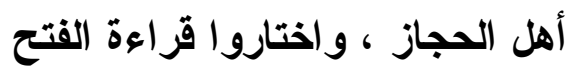

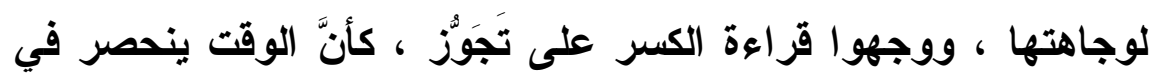

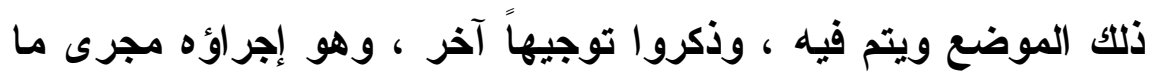

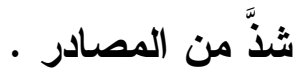

ساق هذا القول ابن عطية وتبعه أبو حيان (') .

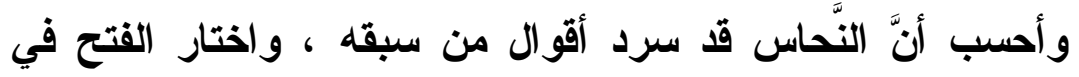

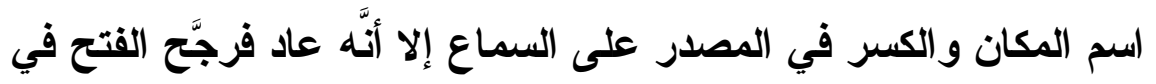

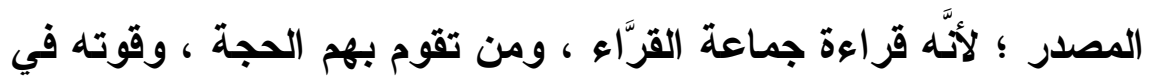

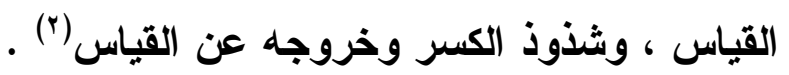

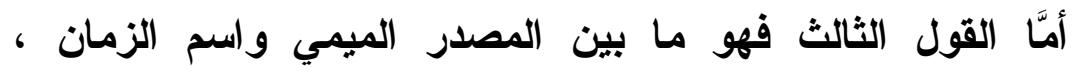
المصدر الميمي في قراءة الفتح ، واسم الزمان في قراعة الكسر ،

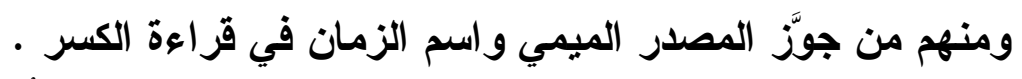

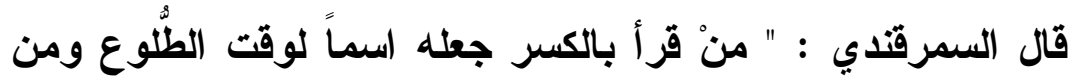

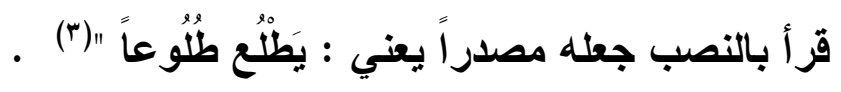

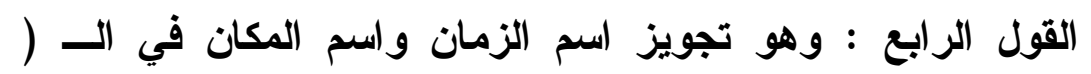

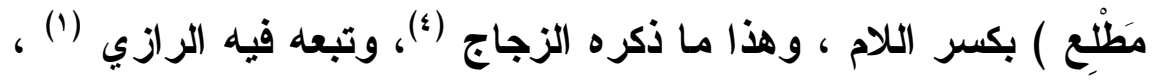

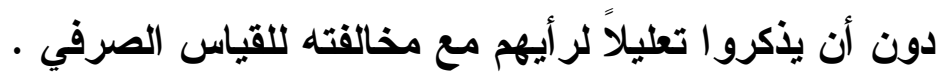

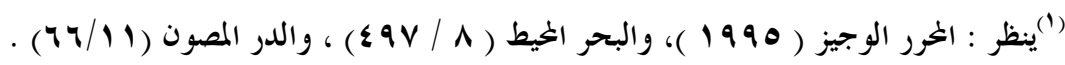

$$
\begin{aligned}
& \text { (广) }
\end{aligned}
$$

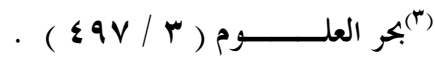

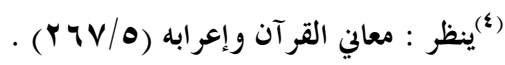

$$
\begin{aligned}
& \text { - - r.rq - }
\end{aligned}
$$


و القول الخامس : وهو ما انفرد البقاعي بذكره من احتمال المصدر

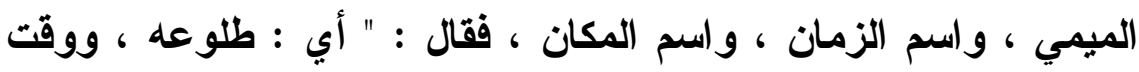

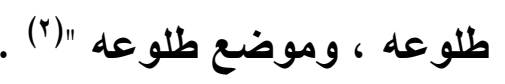

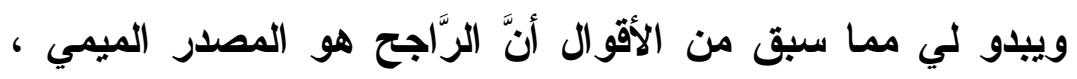

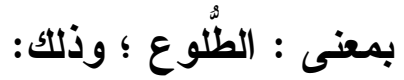

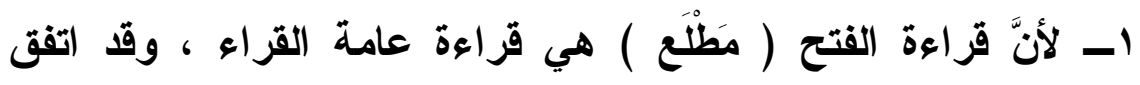

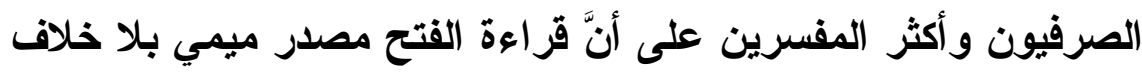
بينهم في ذلك .

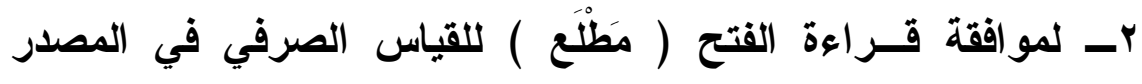

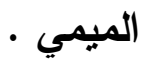
بــ لأنَّ المصدر الميمي هو المتسق مع سياق الآية ، ولا معنى لاسم المكان في هذا الموضع.

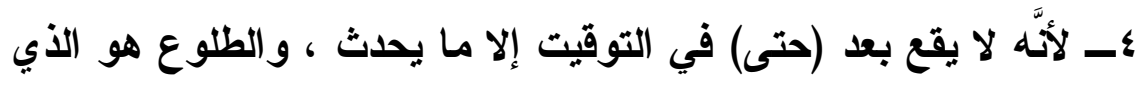

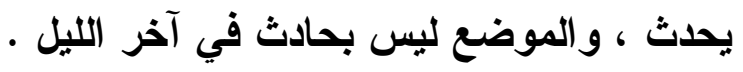
مَوْعِد آخرَ

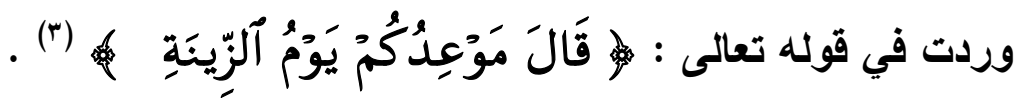
الـ ( مَوْعِد ) في هذه الآية جواب أجاب به موسى عليه السلام

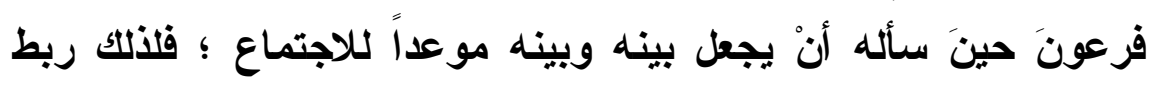

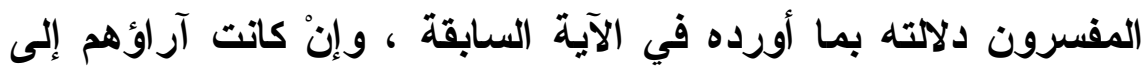

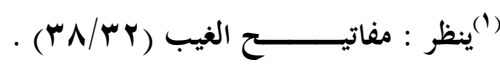

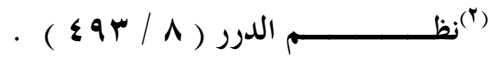

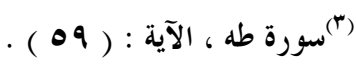

$$
\begin{aligned}
& \text { - } Y \cdot M V=
\end{aligned}
$$


الزمان أقرب ؛ لوجود ما يعضده كما سنعرف لاحقاً في موضعه ، ويمكن

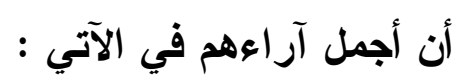

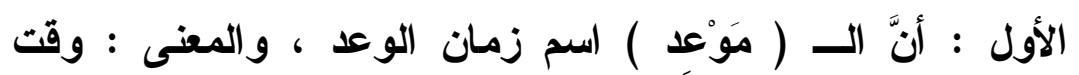

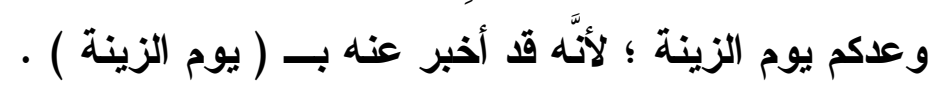

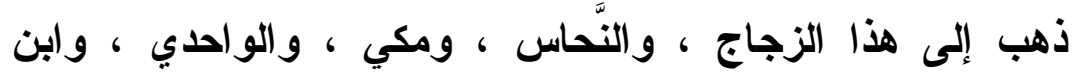

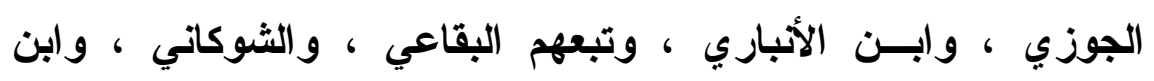

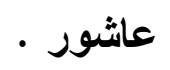

قال الزجاج : " وقت موعدكم يوم الزينة " (1) .

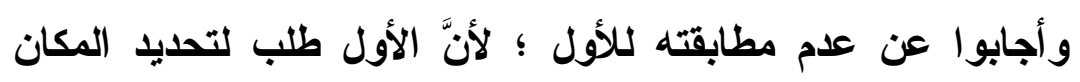

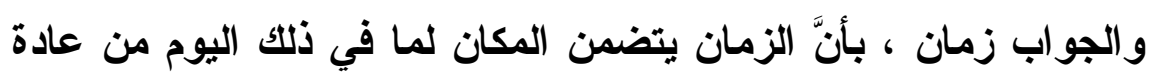

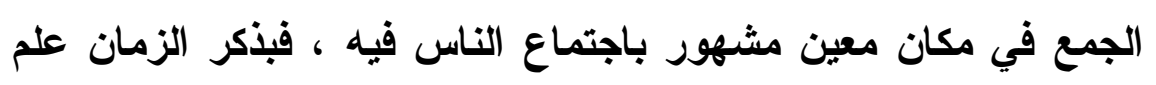

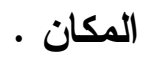

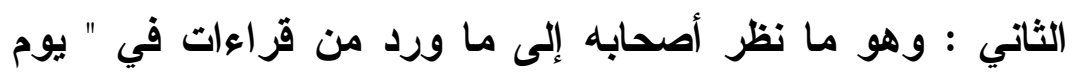

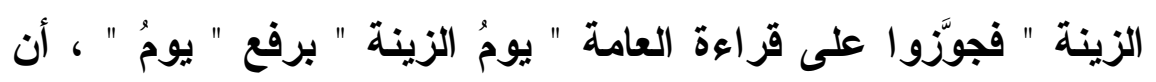

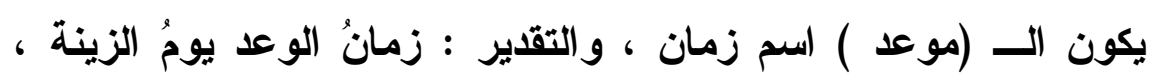

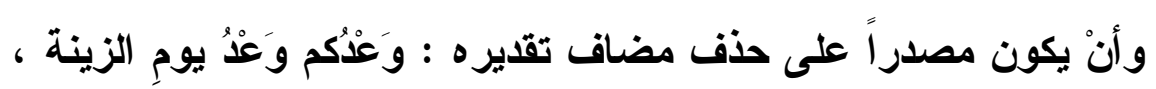

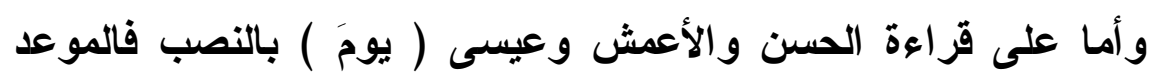

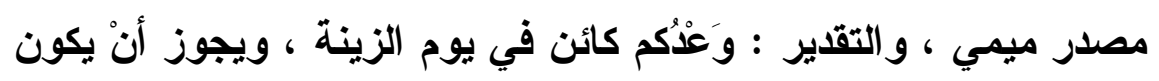

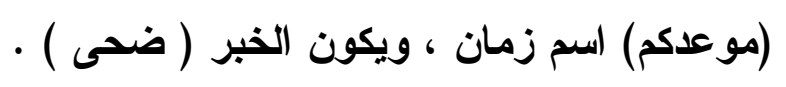

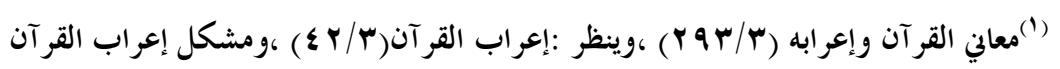

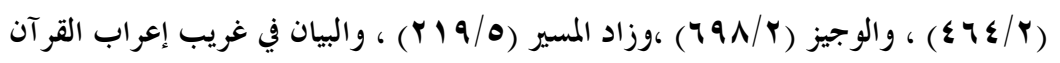
. (11N/r) 


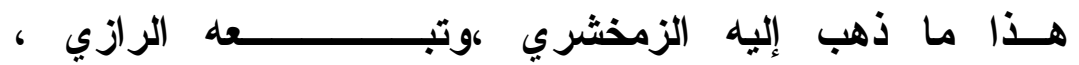

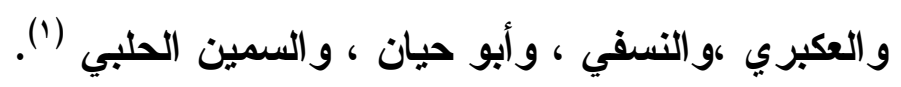

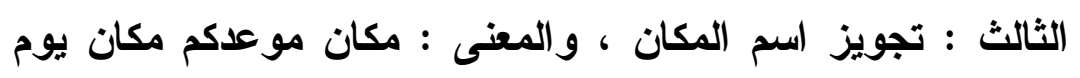

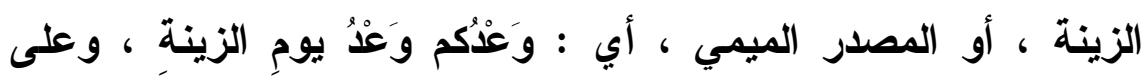

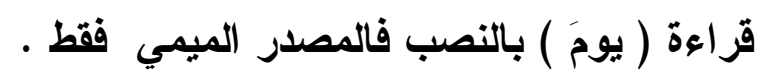

قال البيضاوي : " من حيث المعنى يدل على مكان مثلى مثتهر باجتماع

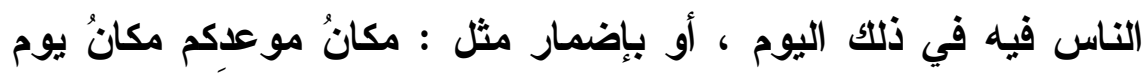

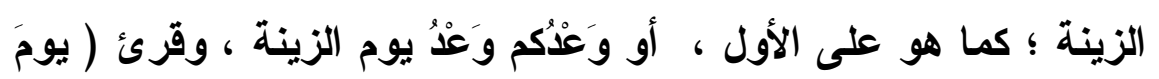

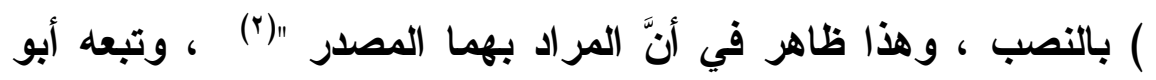

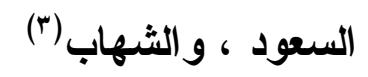

الرابع : أنَّها تحتمل المصدر الميمي ، أي : وَعْدُكم وعدُ يوم الزينة

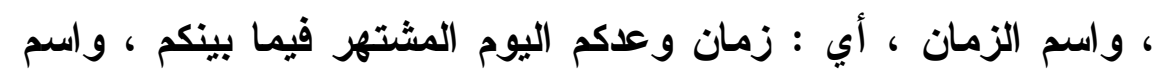

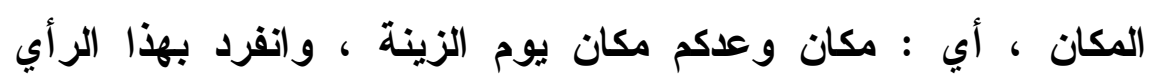

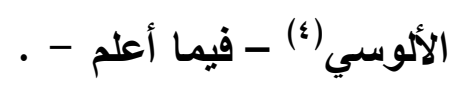

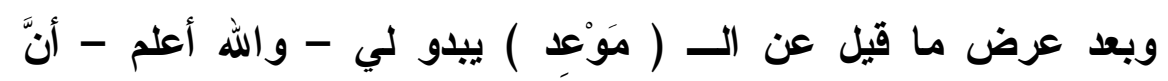

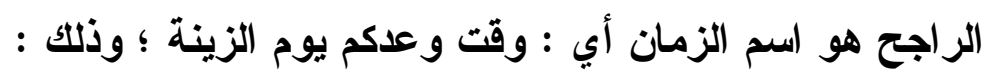

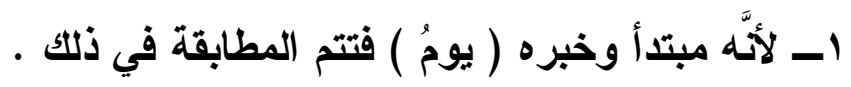

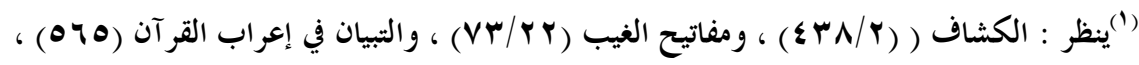

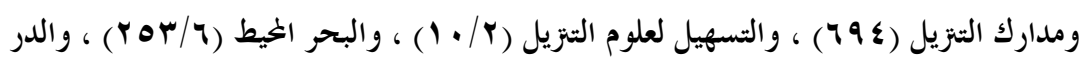

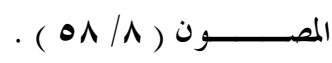

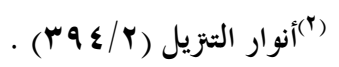

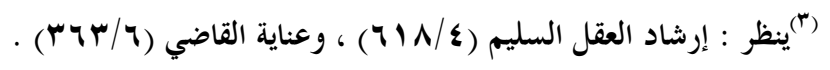

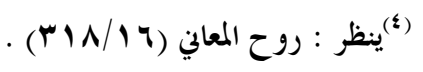




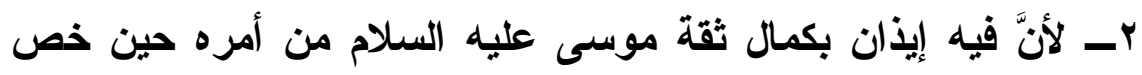

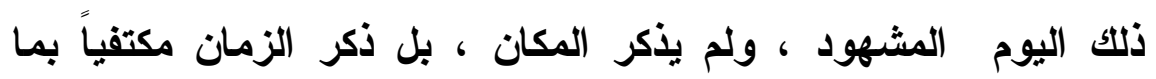

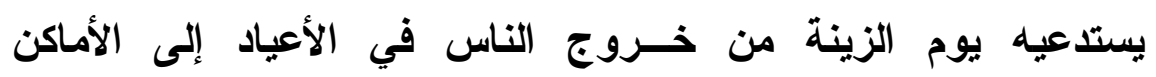

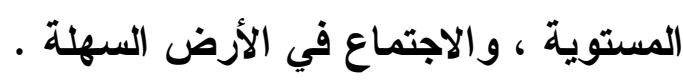

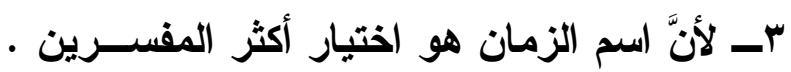




\section{المخايمة وأمهم النتشائج :}

بعد هـــه الجولة في كتاب الله - عز وجل - مع صيغتين صرفيتين

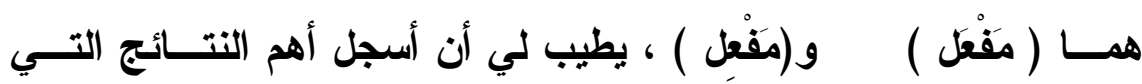

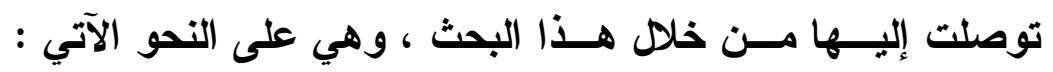

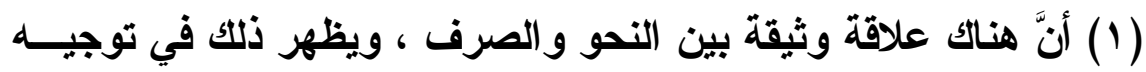

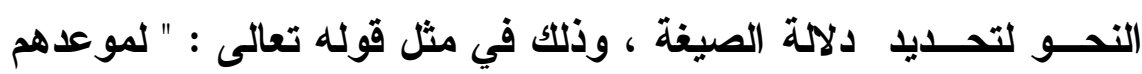

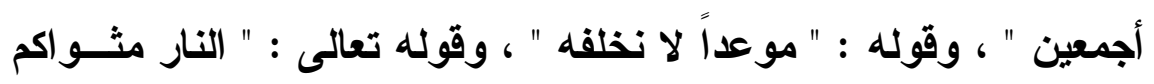
خالدين فيها

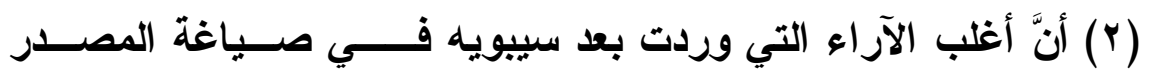

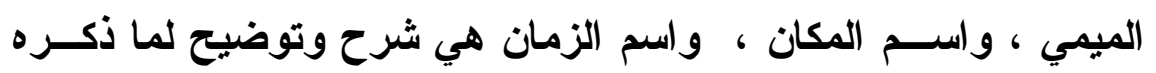

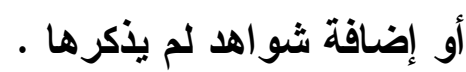

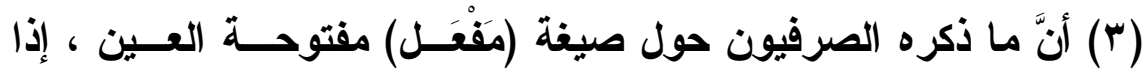

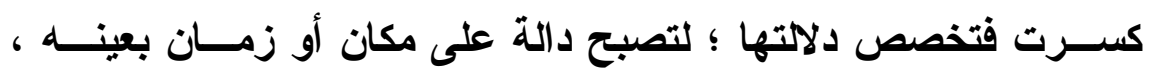

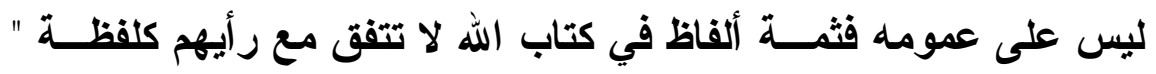

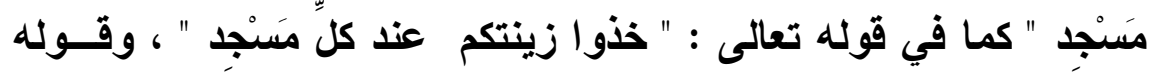

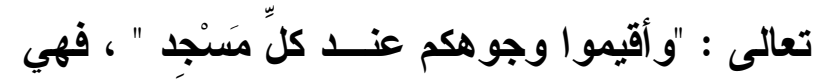

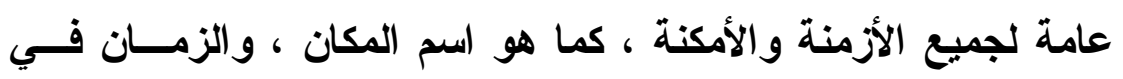

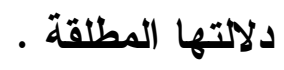

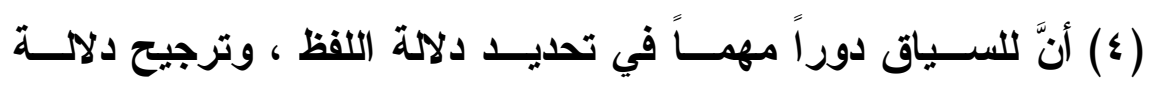
على أخرى · (ه)

(0) قد تترجح دلالة لفظ من الألفاظ بالنظر إلـى المعنـى المعجمـــي

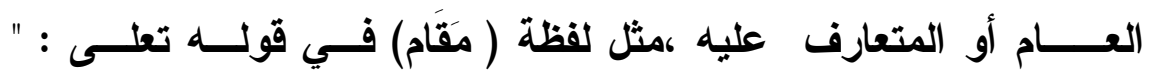
و اتخذوا من مقام إبر اهيم مصلــى " . 


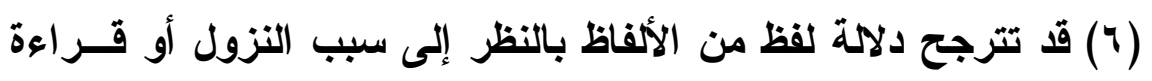

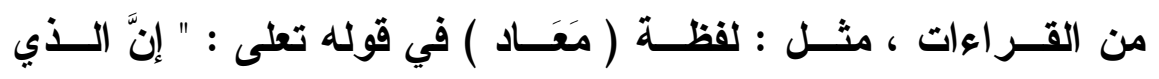

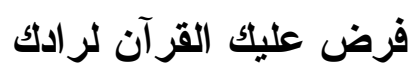
إلى معاد " .

وما توفيقي إلا بالله عليه توكلت و إليه أنيب 


\section{أوراً : المصسادر والمراجع المطبومة :}

أدب الكاتب : لأبي محمد عبدالله بن مسلم قتيبة الــدينوري ، تحقيق : محمد محي الدين عبدالحميد ، القـــاهرة : المكتبـــة

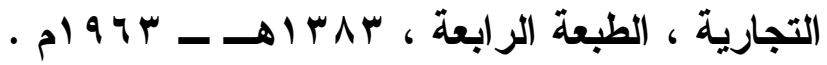
إرشاد العقل السليم إلىى مزابيا الكتاب الكريم : للقاضي محمد بن محمد العمادي الحنفي ، علق عليه وضبط نصه : محمـــ صبحي حسن حلاف ، بيروت : دار الفكر ، الطبعة الأولـى ،

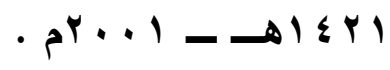
أسساس البلاغة : لأبي القاسم محمود بن عمر الزمخشــري ،

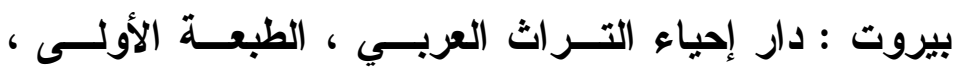

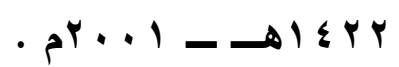

إصلاح المنطق : لابن السكيث ، اعتنى بتصحيحه : محمــ

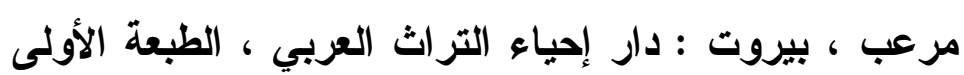

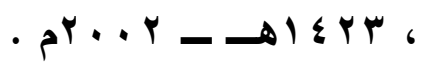

الأصول في النحو : لأبي بكر محمد بن سهل بـن الســراج البغدادي ، تحقيق : د ـ ـ عبدالحسـين الفتـــي ، بيــروت :

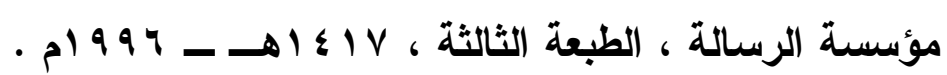
الأعلام: لخير الدين الزركلي ، بيروت : دار العلم للملايـيـين

$$
\text { - 1919، }
$$

الأغاني_: لأبي الفرج علي بن الحسين الأصفهاني ، تحقيـق

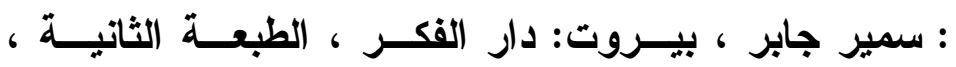
- 1900 
الإنصاف في مسائل الخلاف : لأبي البركات بن عبــالرحمن

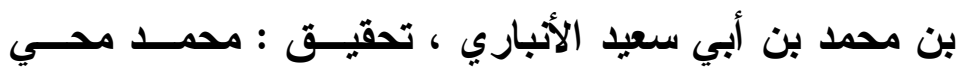

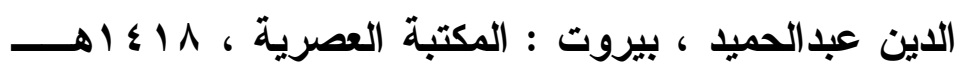

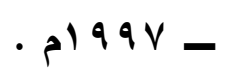

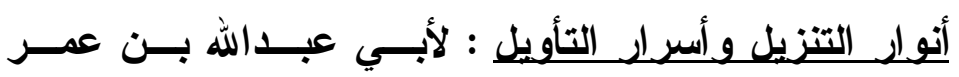

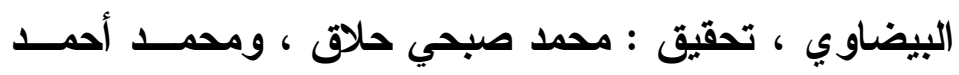

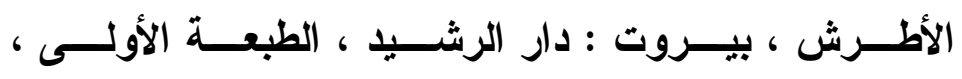

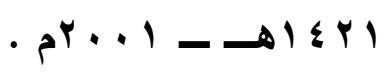

الإيضاح في شرح المفصل : لابن الحاجـب ، تحقيـق : د د .

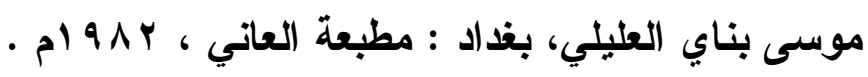

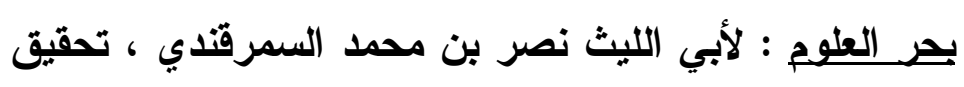

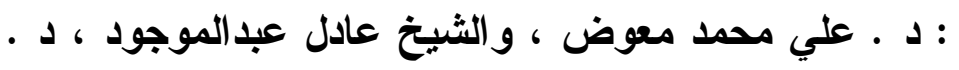

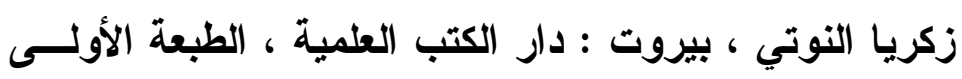

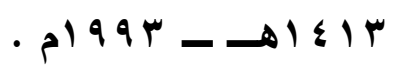

البحر المحبط : لأثير الدين محمد بـن يوسـف بــن حيـان

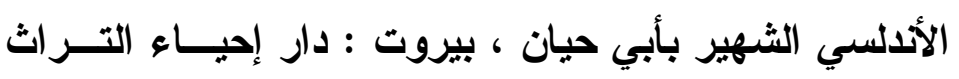

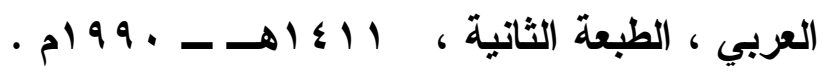

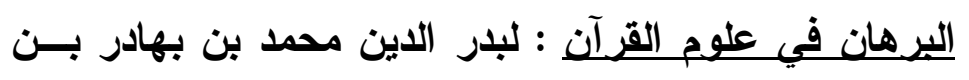

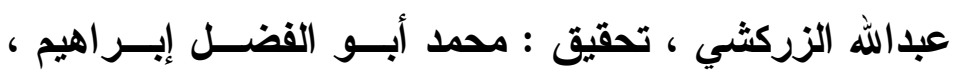

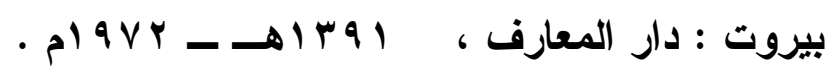

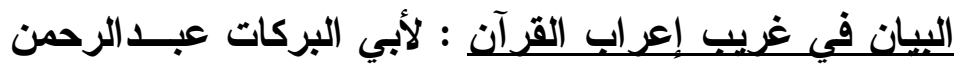

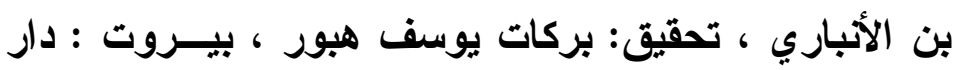

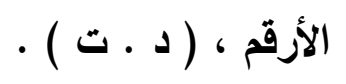


البيان و التعريف بما في القرآن من أحكام التصــيف : د .

محمد بن حسين الثـــقيطي ، جــــة : دار القبلــة للثقافــة

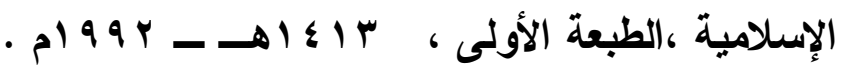
تاج العروس من جواهر القاموس : لأبي القيض محمد بـن الرزاق مرتضى الزبيدي ، تحقيق : علي شيري ، بيــروت :

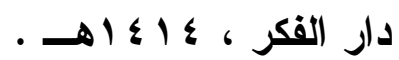

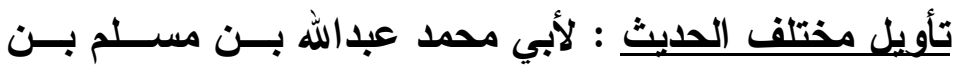

قتيبة الدينوري ، تحقيق : محمد زهري النجار ، بيــروت :

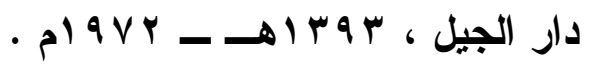

التبيـن في إعراب القرآن : لأبي البقاء عبدالله بن الحسـين

العكبري ، تحقيق : سعد كــريم الفقــي ، المنصــورة : دار

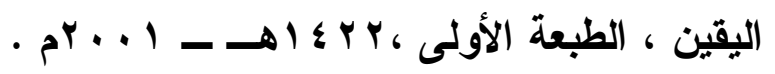

التبيان في تصريف الأسماءي : لأحمد حسن كحيل ، القاهرة :

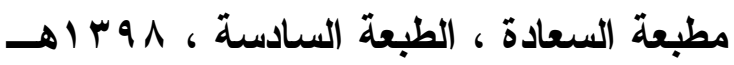

التحرير والتنوير : للشيخ محمد الطاهر ابن عاثور ، تونس

$$
\text { : } 99 \text { V ، دار سحنون : }
$$

تذكرة النحاة : لأبي حيَّان محمد بــن يوســف الأدلأســي ، تحقيق : د ـ عفيف عبدالرحمن ، بيروت : مؤسسة الرسالة

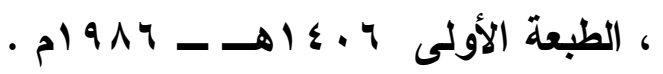

تسهيل الفوائد وتكميل المقاصد : لابن مالك محمد بن عبدالله الطائي الجياني ، تحقيق : د ـ ـ محمد كامل بركات ، القــاهرة

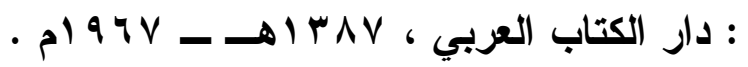


(YT) (التسهيل لعلوم التنزيل : لمحمد بن أحمد بن جزي الغرناطي

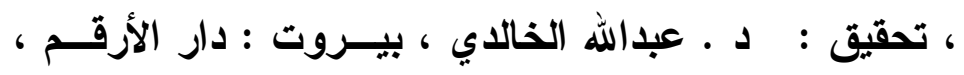

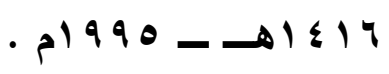

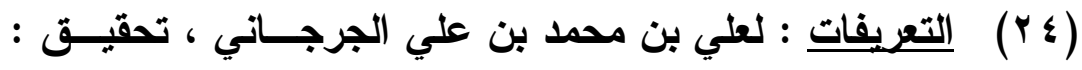

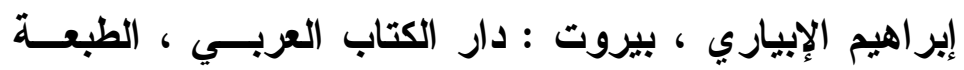

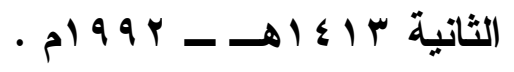

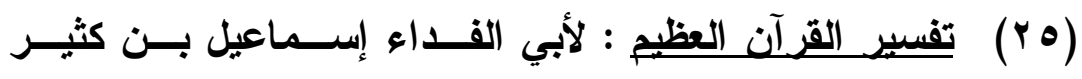

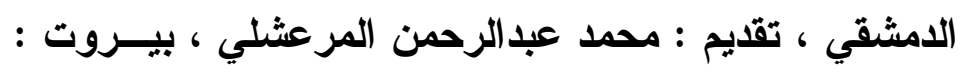

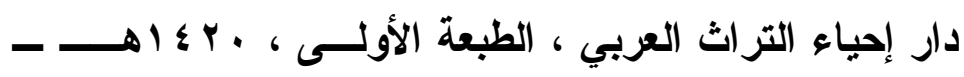

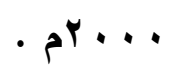

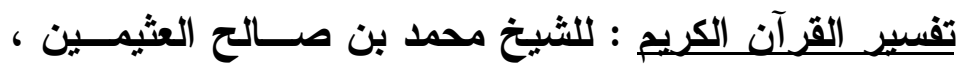

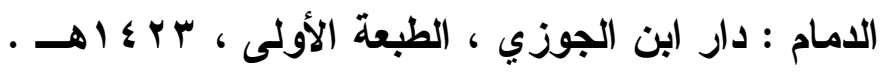

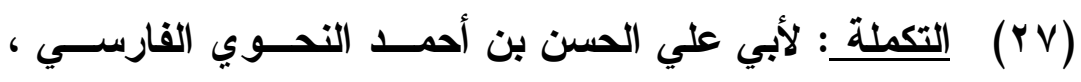

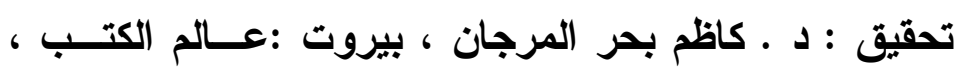

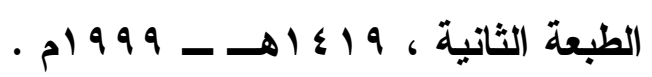

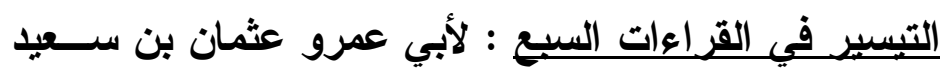

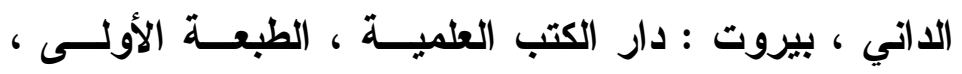

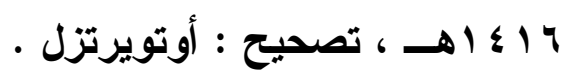
تيسير الكريم الرحمن في تفسير كلام المنان : لأبي عبدالله

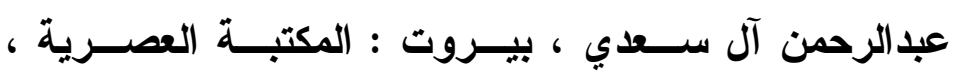
• 


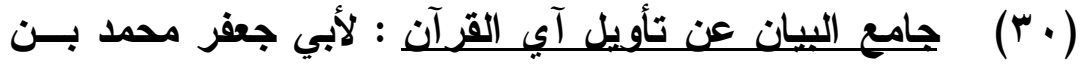

جرير الطبري ، تحقيق : صدقي جميل العطـــار ، بيـروت :

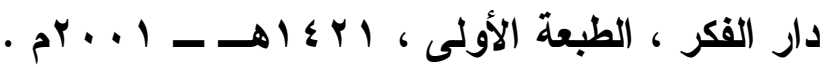

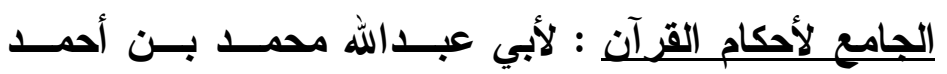

القرطبي ، تحقيق : صدقي جميل العطـــار ، بيـروت : دار

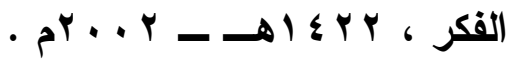

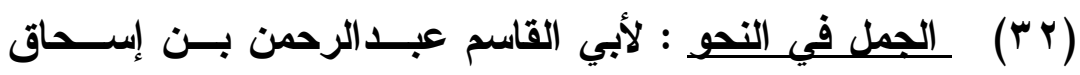

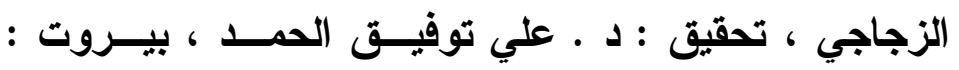

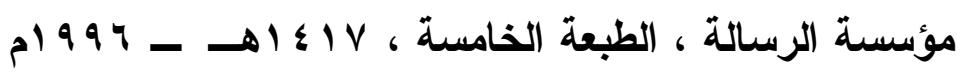

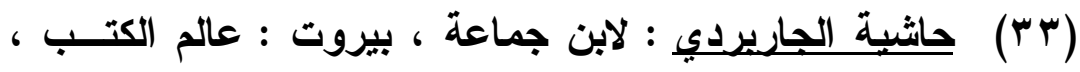

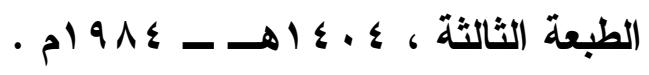

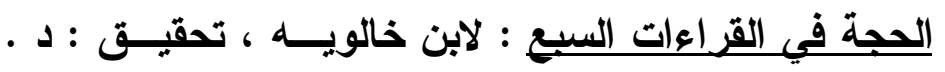

عبدالعال سالم مكرم، بيروت : مؤسسة الرســالة ، الطبعـة التهات

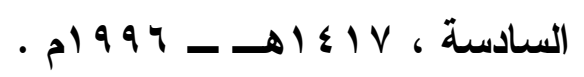

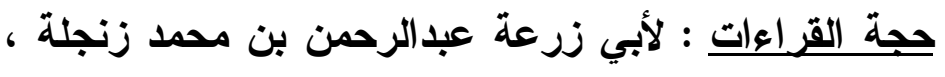

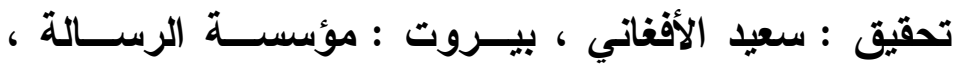

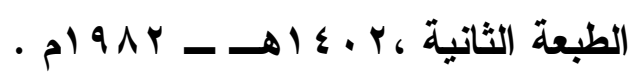

خزانة الأدب ولب لباب لسان العرب : لعبد القادر بن عــر

البغدادي ، تحقيق : عبدالسلام محمد هـارون ، القــاهرة :

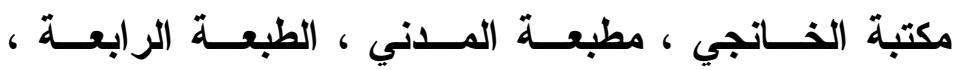

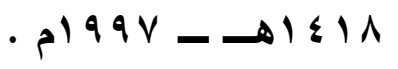


(TV)

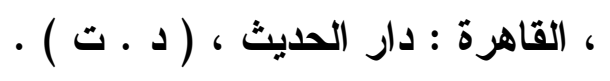

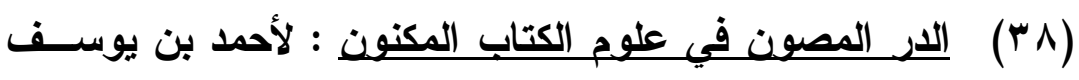

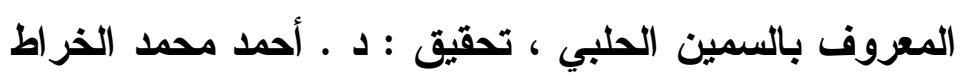

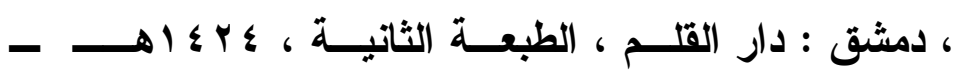

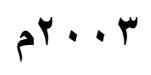

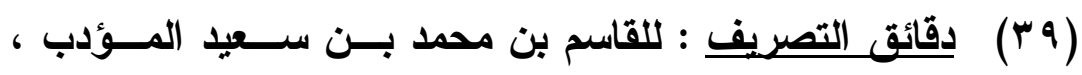

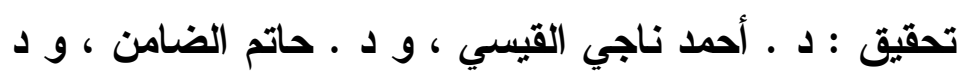

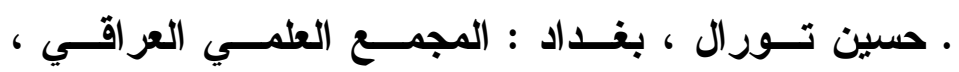

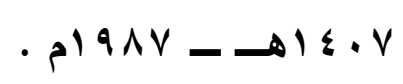

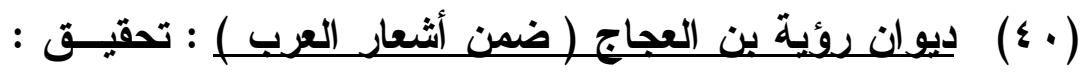

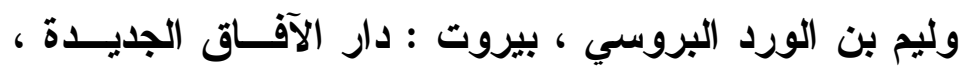

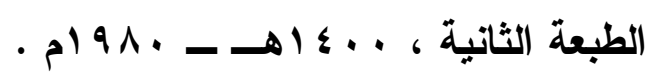

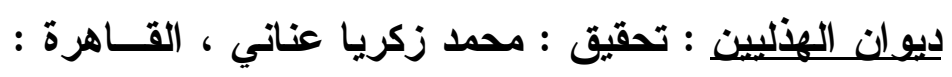

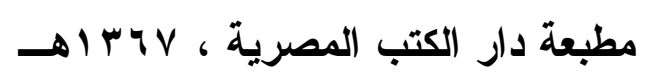

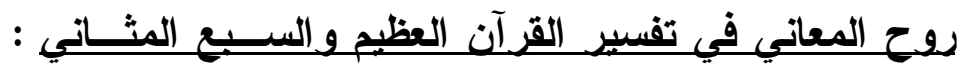

لأبي الفضل شهاب الدين محمود الألوسي ، تحقيق : محمـــ

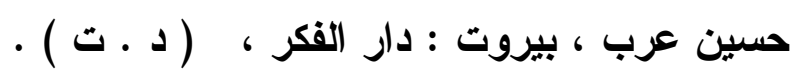

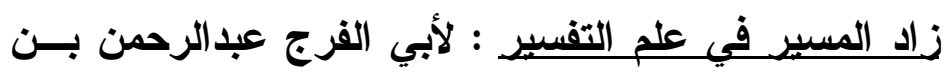

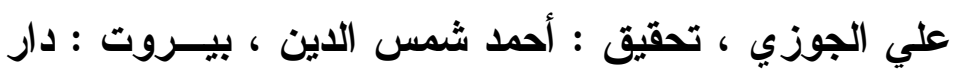

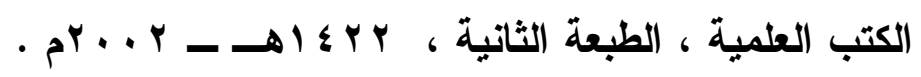

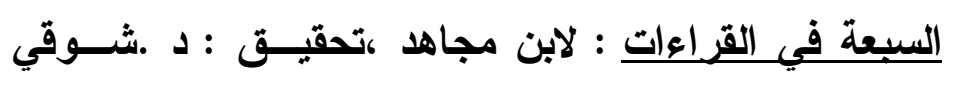

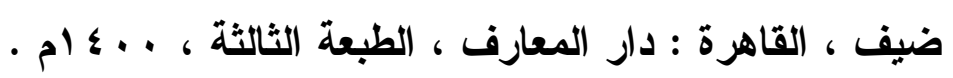


شرح ابن الناظم على ألفية ابن مالك : لأبــي عبــالله بــدر

الاين محمد ابن مالكك ، تحقيق : محمد باسل عيون

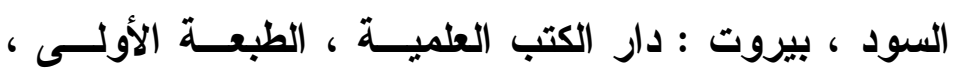

$$
\text { • . . . . . }
$$

شيرح أثشعار الهذلبين : لأبي سعيد الحسـن بـن الحسـين

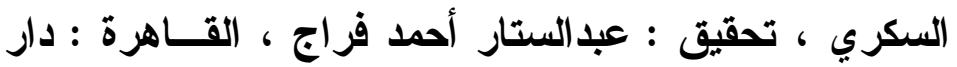

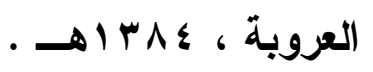

شرح التسهيل : لابن مالك محمــد بـن عبــالله الطــائي

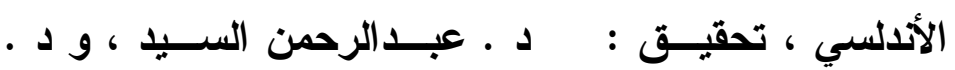

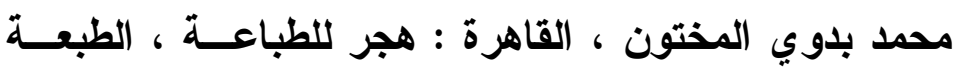

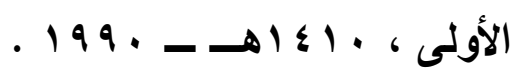

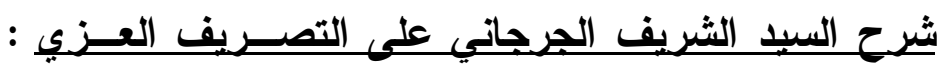

تحقيق : محمد الزفزاف، القاهرة : مطبعة حجازي ، الطبعة

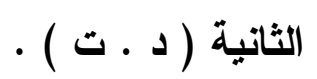

شرح شافية ابن الحاجب : لرضي الدين محمد بن الحسـن

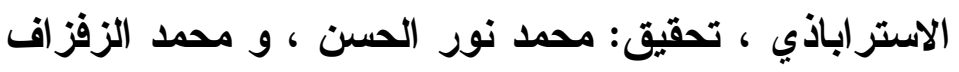

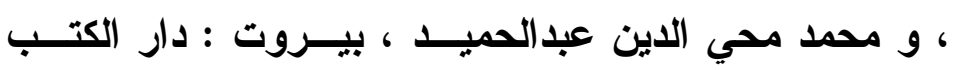

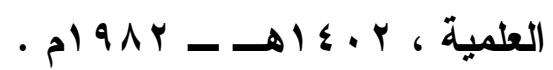

شرح شذور الذهب في معرفة كلام العرب : لابــن هثــام

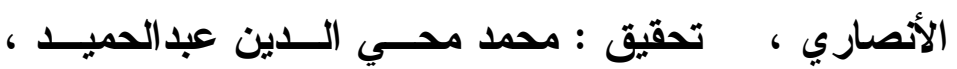
بيروت : المكتبة العصرية ، توزيع دار الفكر ، ( د ـ ت ) . 
شرح كافبة ابن الحاجب : لرضي الاين محمد بن الحســن

الاستراباذي ، تحقيق : أحمد الســيذ أحمــد ، القــاهرة :

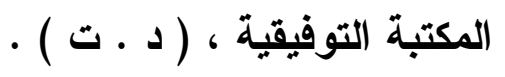

شرح الكافية الثـافية : لأبي عبدالله محمد بن عبــدالله بـن

مالك الجياني ، تحقيق : علي محمد معوض عادل أحمـــ

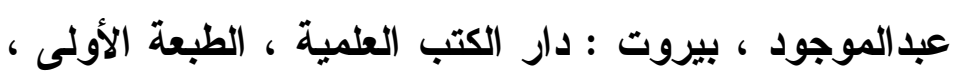
•

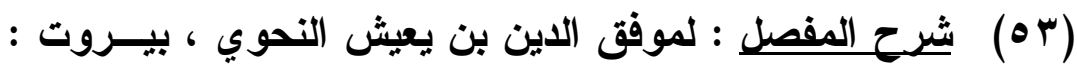

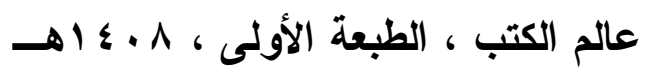

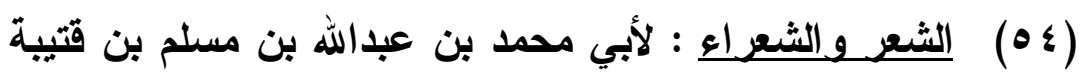
، تحقيق : حسن تميم ، و محمد العريــان ، بيـروت : دار

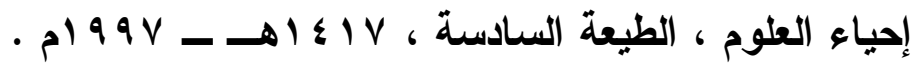
(0) صحبح مسلد : لأبي الحسين مسلم بن الحجــاج النيسابوري ، تحقيق : محمد فـؤاد عبدالباقـي ، بيروت : دار إحيــاء

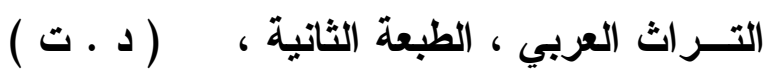

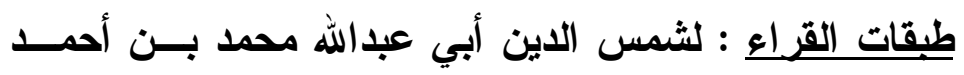
$(07)$ الأهبي ، تحقيق : أحمد خان ، الرياض : مركز الملك فيصل

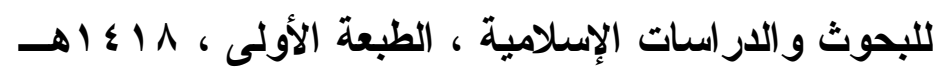

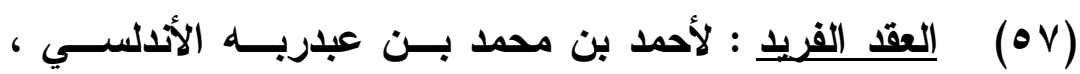
تحقيق : محمد عبــلالقادر شــاهين ، بيـروت : المكتبــة

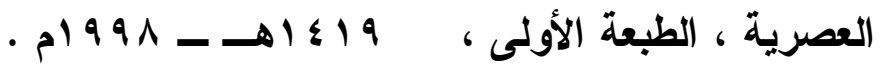


( العلل ومعرفة الرجال : لأبي عبدالله أحمد بن حنبل الثيباني ، تحقيق : وصي الله بن محمد عباس ، بومبــاي : الـــدار

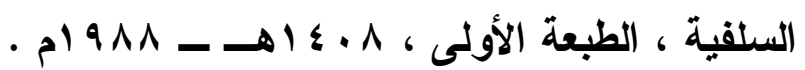

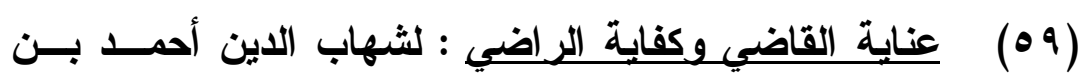
محمد الخفاجي ، تحقيق : الثيخ عبدالرزاق المهدي، بيروت

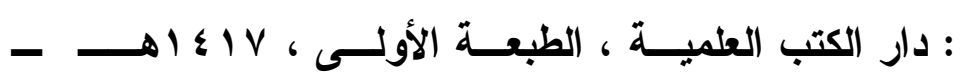
- $199 \mathrm{~V}$

عنقود الزواهر في الصرف : لعلاء الدين علي بــن محمـــ القوشجي ، تحقيق : د ـ ـ أحمد عفيفي ، القاهرة : مطبعـة

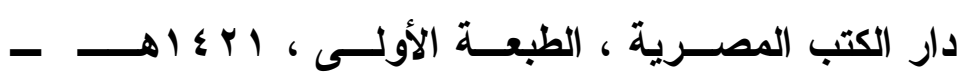

$$
\text { p. } 1
$$

غاية النهايــة في طبة امــات القراع : لشمس الدين محمد بن

محمد الامشقي ابن الجزري ، القاهرة : مكتبــة الخــاتجي ،

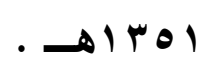

الفصول المفيدة في الواو المزيدة : لصلاح الدين خليل بـن

كيكلدي العلائي ، تحقيق : حسن موسى الشاعر ، عمــان :

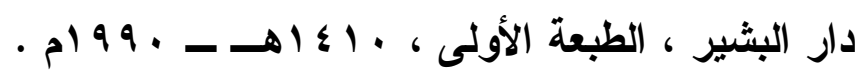

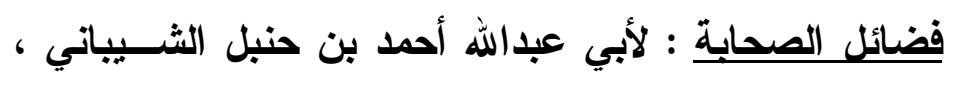

تحقيق : د . وصي الله محمد عباس ، بيــروت : مؤسســة

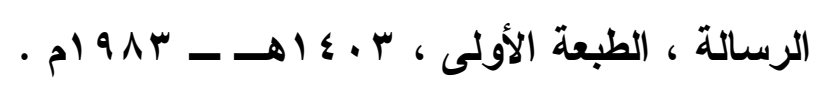

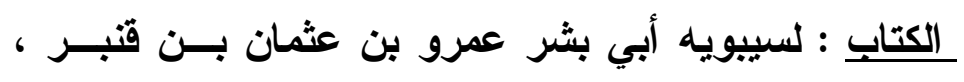

تحقيق : عبدالسلام محمد هارون ، بيــروت : دار الجيـلـل ، بلـيـل

$$
\text { الطبعة الأولى ، ( د ـ ت ) . }
$$


الكثـاف عن حقائق التنزيل : لأبي القاسم محمود بن عــر

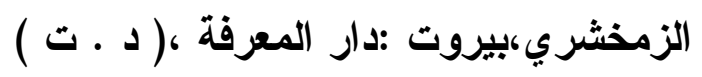

الكشف عن وجوه القراعات السبع وعللها وحجيها : لأبسي محمد مكي بن أبي طالب القيسي ، تحقيق : د ـ محي الاين رمضان ، بيروت : مؤسسة الرسالة ، الطبعــة الخامســة ،

$$
\text { p) } 99 \vee-\infty \leqslant 11
$$

كنز العمال في سنن الأقو ال والأفعال : لعلي بن حسام الدين الهندي البرهان فوري ، بيروت : مؤسسة الرسالة ، الطبعة

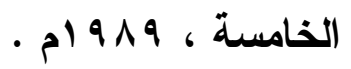

لباب النقول في أسباب النزول : لجلال الــدين السـيوطي ،

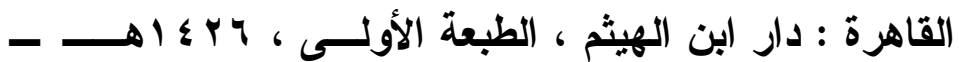

$$
\cdot r_{r} \cdot 0
$$

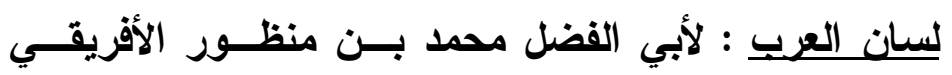

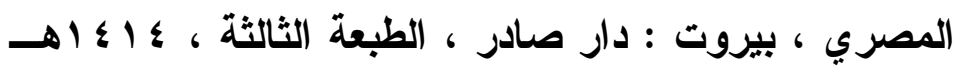
- ค) $99 \leq-$

المبسوط في القراعات العثر : لأبي بكر أحمد بن الحسـين الأصبهاني ، تحقيق : سبيع حمزة حاكمي ، جدة : دار القبلة

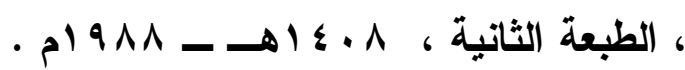
مجمع الأمثال : لأبي الفضل أحمد بــن محمـــ الميـــــي ، تحقيق : محمد محسـي الـــين عبدالحميــــ ، بيـروت : دار

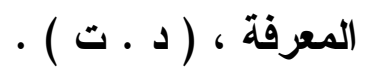

مجمع الزوائد ومنبع الفوائد : لنور الدين علي بن أبي بكر

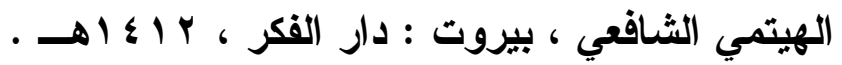


، المحرد الوجيز : لأبي محمد عبدالحق بن عطية الأندلسي (VT) تحقيق : عبدالله إبراهيم الألصاري ، والسيد عبدالعال السيد

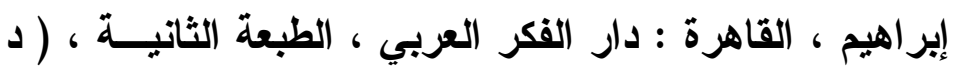

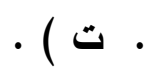

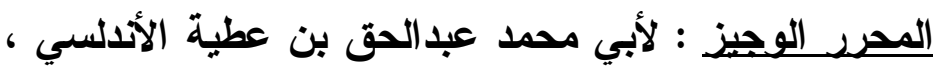

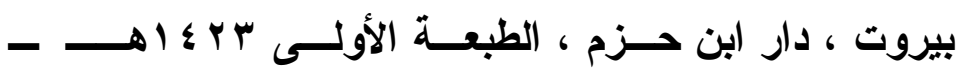
•

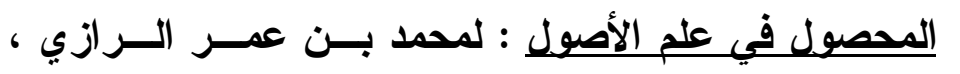

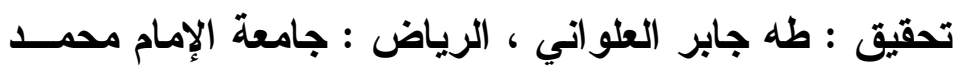

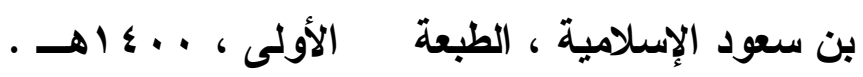

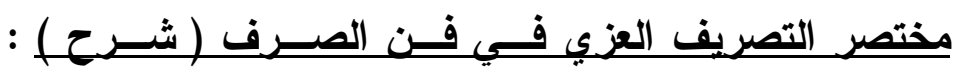
لمسعود عمر سعد الدين التفتازاني ، تحقيق : دـ ـ عبـدالعال

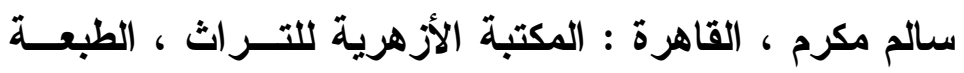

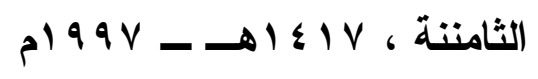

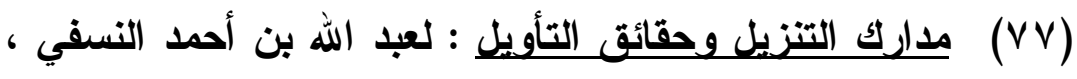

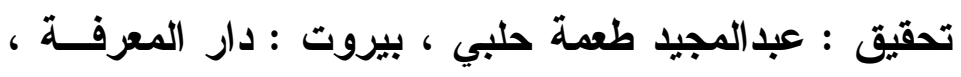

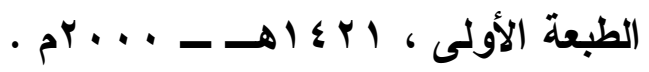

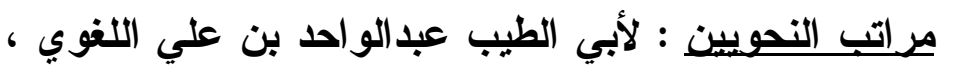
$(\vee \wedge)$

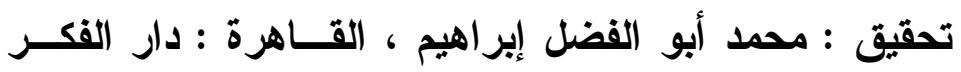

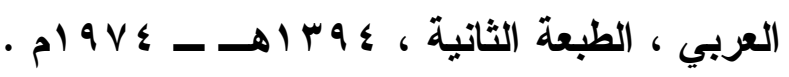

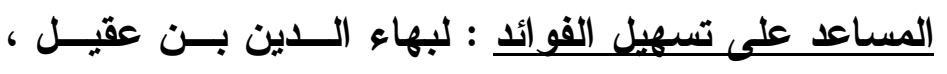

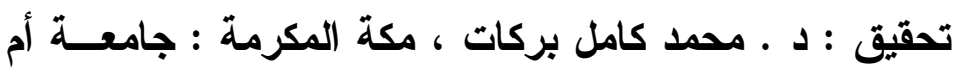


القرى ، مركز إحياء التراث الإسلاهي ، الطبعـة الثانيــة ،

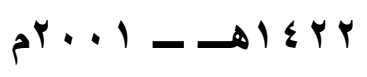

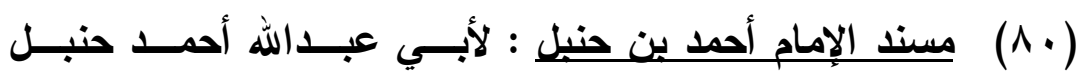

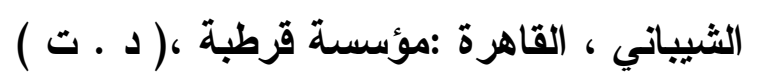

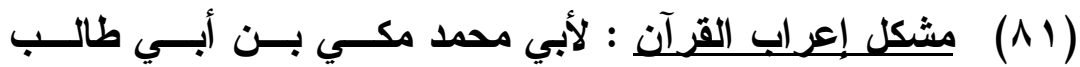

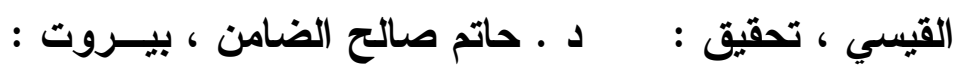

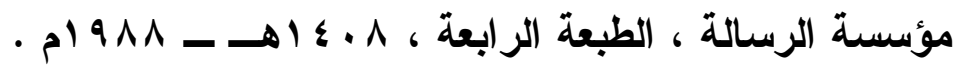

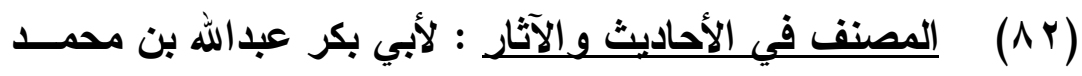

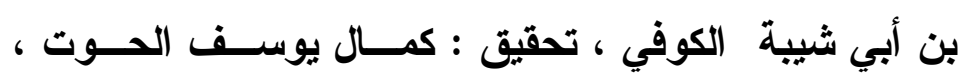

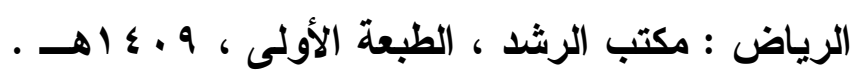

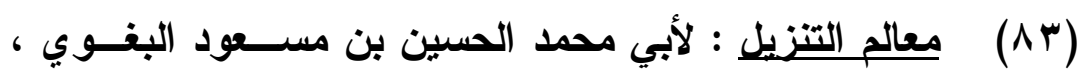

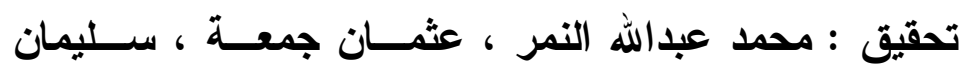

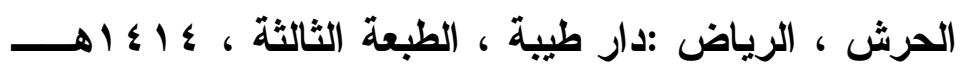

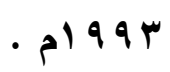

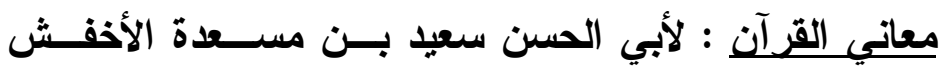

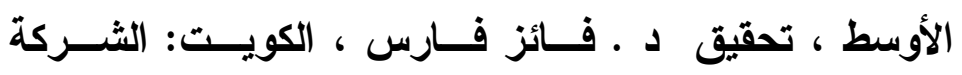

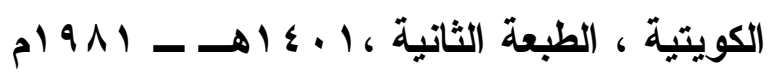

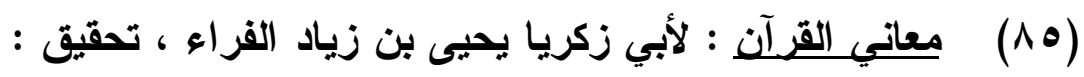

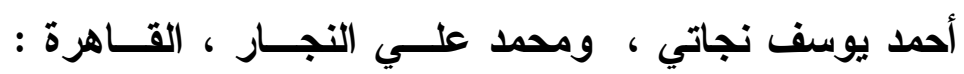

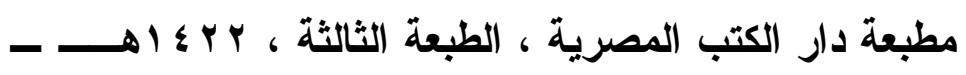

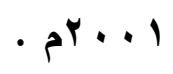


معاني القرآن وإعرابه : لأبي إسحاق إبر اهيم بن السـري

الزجاج ، تحقيق : د عبدالجليل عبده شلبي ، القــاهرة

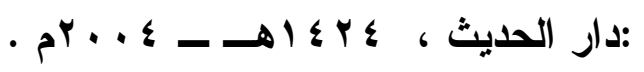

(NV)

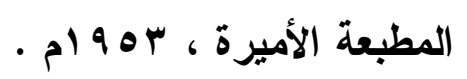

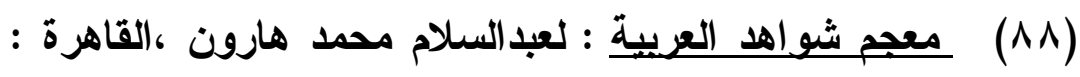

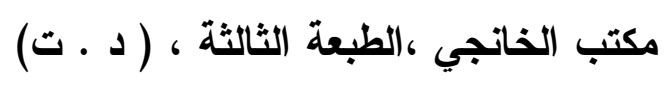

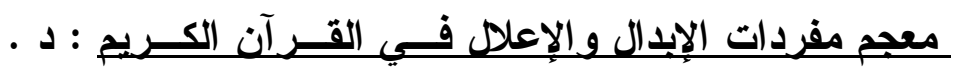

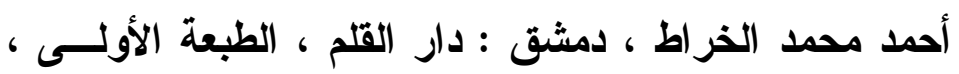

$$
\text { - م) } 9 \wedge 9 \longrightarrow 1 \varepsilon .9
$$

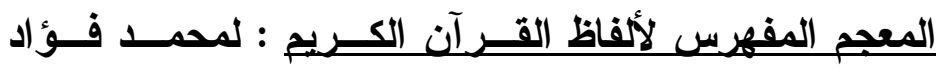

عبدالباقي ، القاهرة : دار الحديث ، الطبعــــة الثانيــة ،

$$
\text { . }
$$

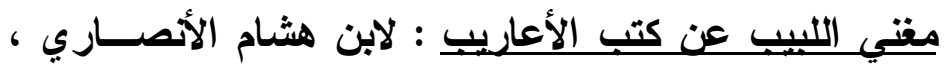

تحقيق : محمد محي الاين عبدالحميل ، بيـروت : المكتبــة

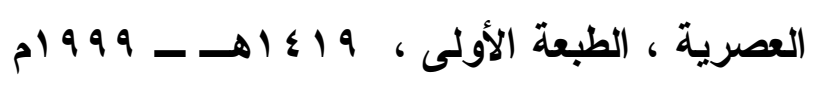

مفاتيح الغيب : لفخر الدين محمد الرازي ، تحقيق : خليـلـل

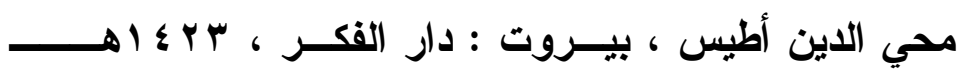

$$
\text { • م. r r r }
$$

مفردات ألفاظ القرآن الكريم : للراغب الأصفهاني ، تحقيق

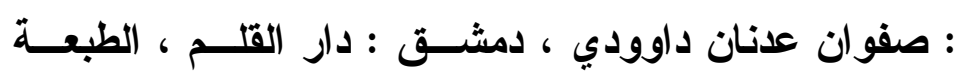

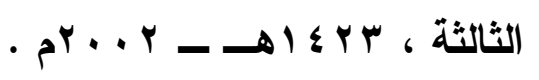


المفصل في صنعة الإعراب : لمحمود بن عمر الزمخشـري

، تحقيق : د . محمد محمــد عبدالمقصــود ، و د ـ ـســن

محمد عبدالمقصود ، القاهرة : دار الكتاب المصري ، الطبعة

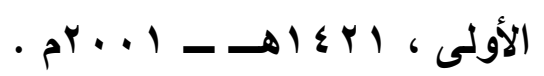

المقتضب : لأبي العباس محمد بن يزيد المبرد ، تحقيـق :

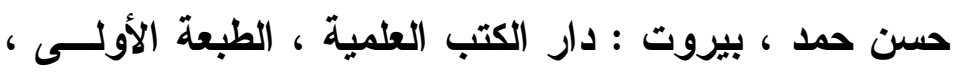

$$
\text { - p) } 999-1 \leqslant r \text {. }
$$

المقرب : لأبي الحسن علي بن مؤمن بن عصفور الإثبيلي

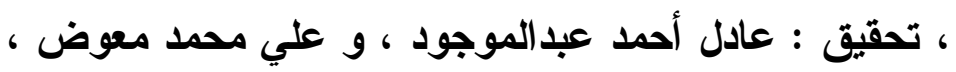

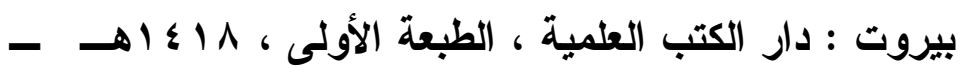

$$
\text { - p) } 991
$$

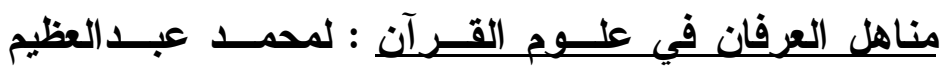

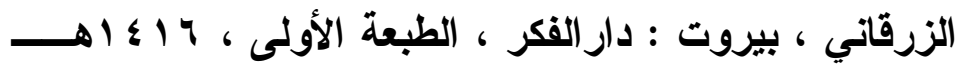

$$
\text { - } 1997 \text { - }
$$

النحو وكتب التفسير : د ـ إبر اهيم عبدالله رفيــدة ، ليبيــا :

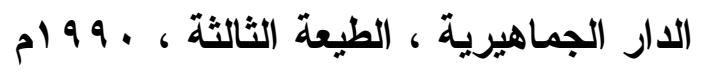

نزهة الطرف في علم الصرف : لأحمد بن محمد المياني ،

تحقيق : د . يسرية محمد إبر اهيم حسن ، القاهرة : مطبعـة

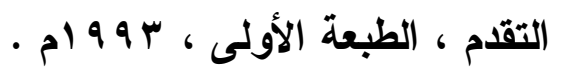

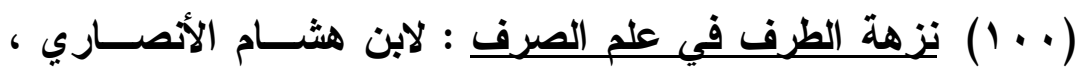

تحقيق : د ـ أحمد عبدالمجيد هريــدي ، القــاهرة : مكتبــة

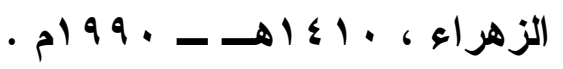


(1 1 (1) نظم الدرد في تناسب الآيات والسور : لبرهان الدين أبسي الحسن إبراهيم البقاعي ، تحقيق : عبدالرزاق غالب المهاي

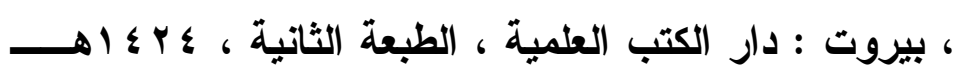

$$
\text { • }
$$

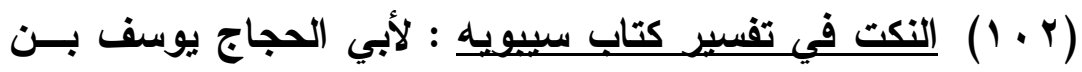

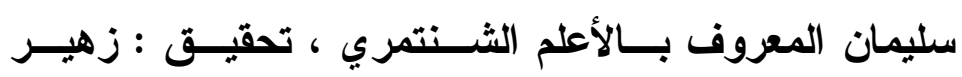

عبدالمحسن سلطان ، الكويت : معهر المخطوطات العربية ،

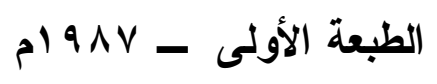

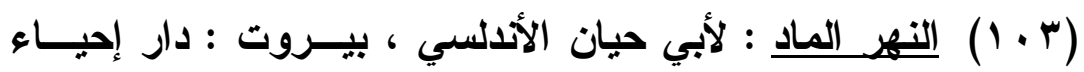

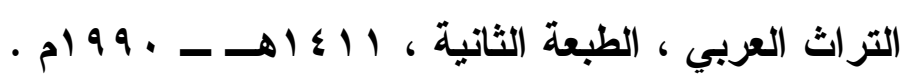

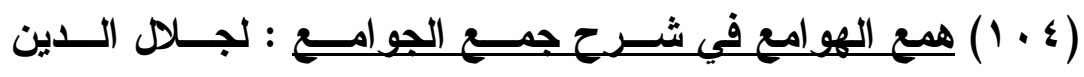

السيوطي ، تحقيق : عبدالسلام محمد هارون ، دـ ـ ـ عبد العال

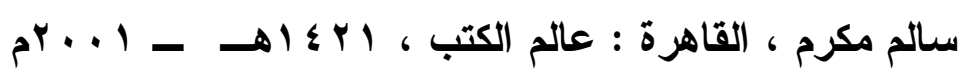

\section{ثانياً - المخطوطات والدوريات :}

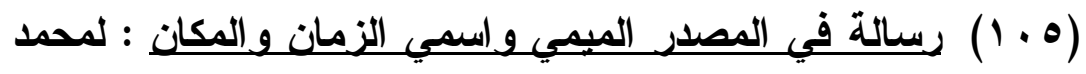

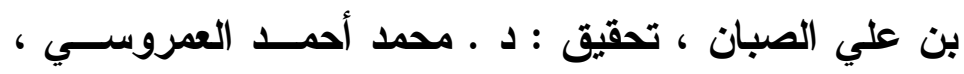

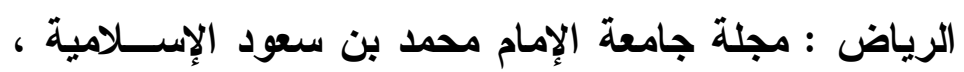




$$
\text { - } r \cdot \bullet \Lambda=
$$

